\title{
A BigH1 alternatív linker hiszton szerepe a Drosophila korai fejlödésben
}

\author{
Doktori (Ph.D.) értekezés
}

\section{Szabó Anikó}

Témavezetők:

Prof. Dr. Boros Imre Miklós

egyetemi tanár

Dr. Henn László Dániel

tudományos munkatárs

Biológia Doktori Iskola

Biokémia és Molekuláris biológia Tanszék Szegedi Tudományegyetem

ELKH Szegedi Biológiai Kutatóközpont

\section{Szeged \\ 2020.}




\section{TARTALOMJEGYZÉK}

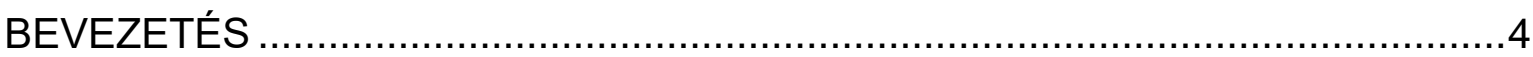

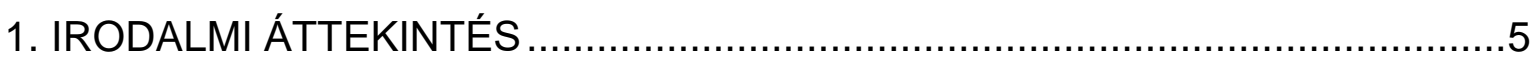

1.1. A KROMATIN SZERVEZŐDÉSÉNEK ALAPJAI ..................................... 5

1.2. HISZTON FEHÉRJÉK ÁLTALÁNOS JELLEMZÖI ...................................... 6

1.3. LINKER HISZTONOK ÉS KAPCSOLATUK A NUKLEOSZÓMÁVAL............ 8

1.4. LINKER HISZTONOK SZEREPE A TRANSZKRIPCIÓ

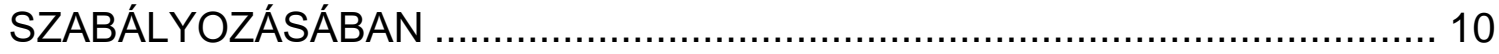

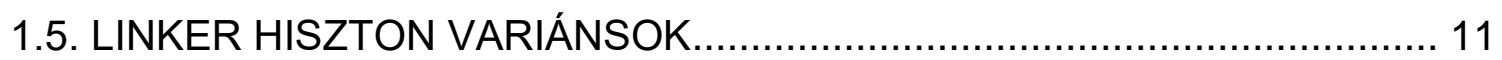

1.6. PETESEJT- ÉS EMBRIÓSPECIFIKUS LINKER HISZTON VARIÁNSOK . 12

1.6.1. Alternatív linker hiszton fehérje Drosophila melanogaster-ben ............ 12

1.6.1.1. Drosophila korai embrionális fejlödés ....................................... 13

1.6.1.2. A BigH1 linker hiszton szerepe a korai fejlődésben ...................... 14

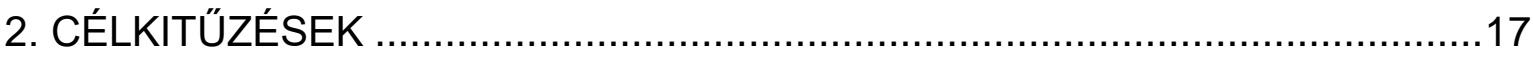

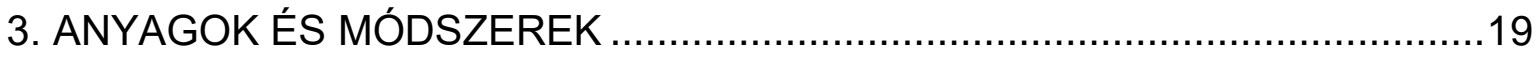

3.1. DROSOPHILA VONALAK ELÖÁLLÍTÁSÁHOZ SZÜKSÉGES PLAZMIDOK

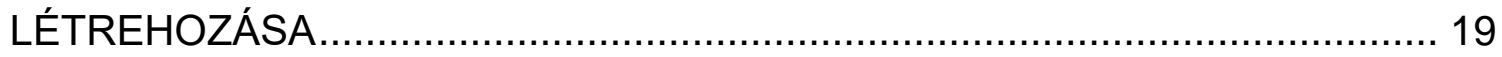

3.1.1. BigH1 nullmutáns ( $\left.d B i g H 1^{\text {NULL }}\right)$ szekvencia klónozása ....................... 19

3.1.2. BigH1 foszforilációs mutáns ( $d B i g H 13 \times F L A G:: P O)$ szekvencia klónozása. 24

3.2. FELHASZNÁLT DROSOPHILA VONALAK ...................................... 26

3.3. DROSOPHILA EMBRIÓK GYÜJTÉSE ÉS ELŐKÉSZÍTÉSE .................... 28

3.4. FEHÉRJÉK MENNYISÉGI VIZSGÁLATA .......................................... 28

3.4.1. Fehérje preparátumok készítése Western blothoz ............................. 28

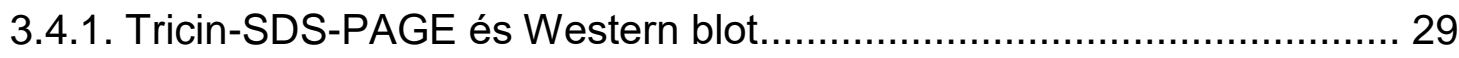

3.5. MNÁZ-ESSZÉ KORAI EMBRIÓ KROMATIN EXTRAKTON ..................... 29

3.6. NUKLEOSZÓMA STABILITÁS VIZSGÁLAT KORAI EMBRIÓKBÓL PREPARÁLT MAGOKON (QINESIn ESSZÉ) …......................................... 30

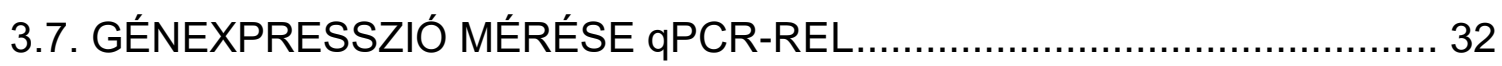

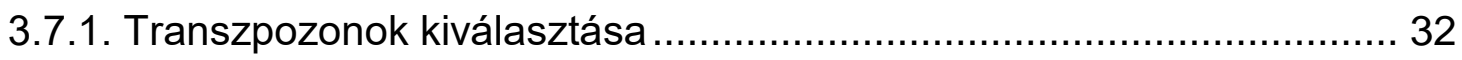

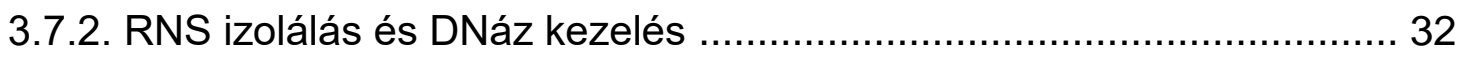

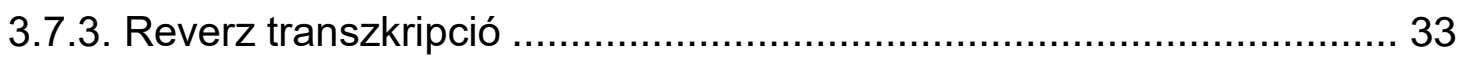

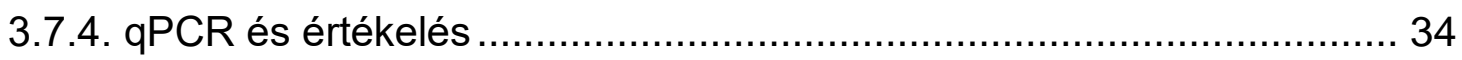

3.8. BIGH1 ÉS H1 FEHÉRJÉK SZEKVENCIÁJÁNAK ÖSSZEHASONLÍTÁSA 34 
4.1. Kanonikus $(\mathrm{H} 1)$ és alternatív (BigH1) linker hisztonok szerepének in vivo összehasonlítását lehetővé tevő rekombináns gének és azokat hordozó transzgenikus Drosophila vonalak létrehozása

4.2. Normál laboratóriumi körülmények mellett $\left(25^{\circ} \mathrm{C}\right)$ a kanonikus linker hiszton képes az alternatív linker hiszton embrionális fejlődésben betöltött szerepének helyettesítésére.

4.3. A BigH1 N-terminális doménje szerepet játszik a fehérje megfelelő expressziójában

4.4. A BigH1 globuláris és C-terminális doménjének cseréje kanonikus $\mathrm{H} 1$ típusúra emelkedett DNS-károsodással jár

4.5. A BigH1 globuláris és C-terminális doménje szükséges a fehérje megfelelő müködéséhez alacsony hőmérsékleten 46

4.6. A HHH mutáns állatokban megváltozik a transzpozon RNS-ek expressziója

4.7. A kromatinszerkezet nukleoszóma szinten hasonló a vad típusban és $H H H$ mutánsban

4.8. A BigH1 jelenlétében stabilabbak a nukleoszómák................................. 53

4.9. A BigH1 könnyebben eltávolítható a kromatinról, mint a $\mathrm{H} 1$ 56

4.10. A Drosophila H1 és BigH1 fehérjék aminosav-szekvenciája eltérő konzerváltságot mutat 60

5. EREDMÉNYEK MEGVITATÁSA .66

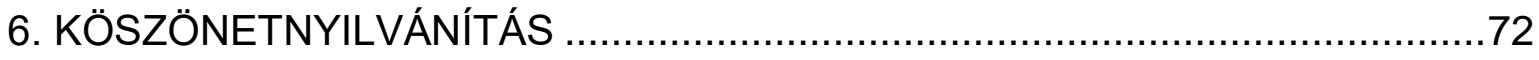

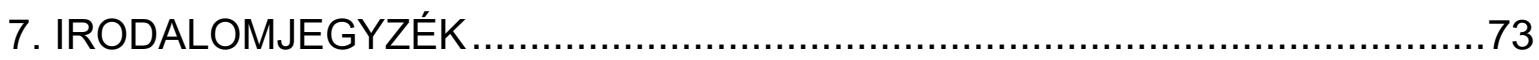

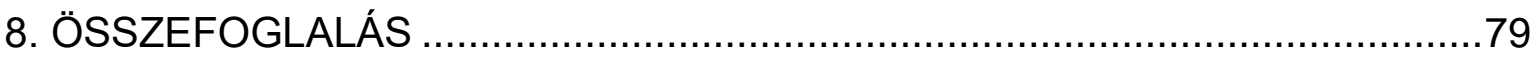

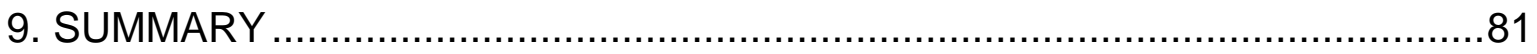

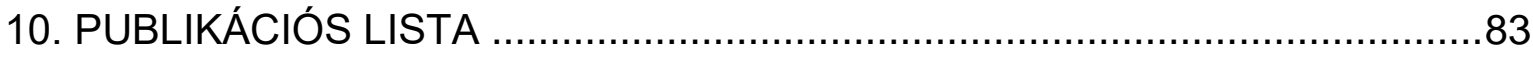

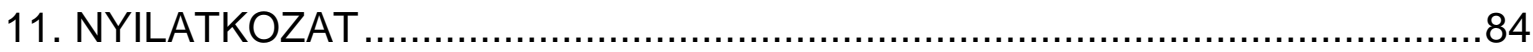

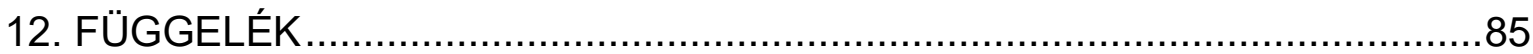

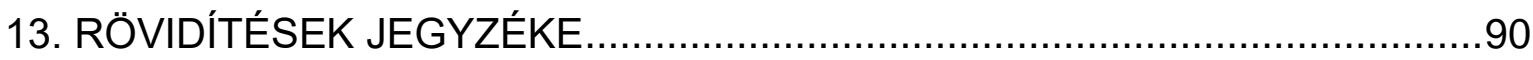




\section{BEVEZETÉS}

A fejlődés kezdeti szakasza minden élőlény számára kritikus időszak, hiszen ekkor alakulnak ki azok a kezdetleges, de létfontosságú struktúrák, amelyek a felnőtt egyed morfológiai alapjait képezik. Az embrionális fejlödés (embriógenezis) az állatvilágban alapvetően hasonló módon zajlik: a petesejt spermium általi megtermékenyítésével veszi kezdetét, mely során kialakul a zigóta. Ezt számos mitótikus osztódás követi az embrió méretének változása nélkül, míg végül a gasztrula stádium alatt kialakulnak a csíralemezek, melyekböl a szervek és szövetek jönnek létre.

Az embrionális fejlődést kezdetben a petesejtben jelenlévő, anyailag örökített termékek irányitják: fehérjék, RNS-ek és egyéb molekulák, beleértve a kromatin szerveződéséhez elengedhetetlen hisztonokat. Ekkor az embrió saját genetikai állománya szinte teljes mértékben inaktív, géntermékek nem képződnek róla. Így a fejlődés első lépései anyailag meghatározott program szerint zajlanak.

Az állatvilágban jellemző, hogy a korai embriógenezis alatt egy alternatív linker hiszton $(\mathrm{H} 1)$ vesz részt a kromatinállomány szervezésében, melyet embrióés/vagy petesejt-specifikus linker hisztonnak nevezünk. Ezen fehérjék vizsgálata a legtöbb állatban korlátokba ütközik, hiszen többségük számos linker hiszton variánssal rendelkezik, melyek funkció tekintetében redundánsak lehetnek. Az ecetmuslica (Drosophila melanogaster) azonban egyetlen szomatikus $\mathrm{H} 1$ fehérjéje mellett egy alternatív linker hisztonnal rendelkezik, a BigH1 fehérjével, ami lehetővé teszi specifikus funkcióinak vizsgálatát. A BigH1 a korai embrionális szövetben, illetve a felnőtt állatok ivarvonalában fejeződik ki, és mindeddig ismeretlen, hogy miben különbözik a szomatikus H1-töl. Munkám célja volt, hogy a BigH1 linker hiszton fehérje szerepét vizsgáljam a korai embriógenezis alatt, illetve felderítsem a BigH1 és szomatikus $\mathrm{H} 1$ fehérjék közötti funkcionális különbségeket. BigH1 mutáns Drosophila vonalakon alkalmazott klasszikus és modern biokémiai módszerek azt igazolják, hogy a BigH1 egy mobilis linker hiszton, amely hozzájárul a korai embrionális fejlődésre jellemző gyors osztódásokhoz, mindemellett pedig nagyobb stabilitást biztosít a nukleoszómák számára a szomatikus H1-el szemben. 


\section{IRODALMI ÁTTEKINTÉS}

\subsection{A KROMATIN SZERVEZŐDÉSÉNEK ALAPJAI}

Az eukarióta élölények örökítő anyaga, a DNS a sejtmagban található, és fehérjék segítségével egy összetett rendszert alkot, amit kromatinnak nevezünk. $A$ kromatinszerkezet meghatároz olyan alapvető folyamatokat, mint a transzkripció, DNS hibajavitás és DNS replikáció. Alapegysége a nukleoszóma, amelyet a négy "core" nukleoszómális hiszton (H2A, H2B, H3, H4) által képzett oktamer és a köréjük tekeredő körülbelül 147 bázispárnyi (bp) DNS alkot. Az oktamert négy heterodimer építi fel: két $H 3 / H 4$ és két $H 2 A / H 2 B$ dimer (1). A nukleoszómákat 10-90 bp hosszúságú linker DNS kapcsolja össze, így kialakítva az úgynevezett „beads-ona-string" (gyöngyfüzér) struktúrát, amely $11 \mathrm{~nm}$ széles és a kromatin elsődleges szerveződési szintje. A nukleoszómákat egy ötödik hiszton fehérje, a $\mathrm{H} 1$ linker hiszton stabilizálja, mely a nukleoszómából ki- és belépő DNS-hez közel kapcsolódik. Az így kialakuló struktúrát kromatoszómának nevezzük. A linker hiszton nem csupán rögzíti a nukleoszómákat, de elösegíti a magasabb szerveződési szintek kialakulását is, így a gyöngyfüzér szerkezet tovább tömörödik a $30 \mathrm{~nm}$-es filamentummá, amely a kromatin másodlagos szerkezeti formája. A filamentumok változatos átmérőjū rostokká szerveződnek, majd sejtosztódás során nagymértékben kondenzálódnak, melynek eredményeként létrejönnek a mitótikus kromoszómák (1. ábra). A funkcionális kromatin sejttípusnak megfelelöen különböző transzkripciós potenciállal rendelkező szakaszokból áll, amelyekben a nukleoszómák és egyéb, kromatinszerveződésben részt vevő faktorok eltérő denzitással vannak jelen. Így megkülönböztethetünk eu- és heterokromatint. Az eukromatikus régiók transzkripciósan aktív géneket tartalmazó kromatin régiók, míg heterokromatin olyan területeken alakul ki, ahol a transzkripció átmeneti (fakultatív heterokromatin) vagy állandó (konstitutív heterokromatin) csendesítésére van szükség (2). A kromatin építököveit, a nukleoszómákat alkotó hiszton fehérjék mindezen szerveződési szintek kialakulásához és fennmaradásához nélkülözhetetlenek. 


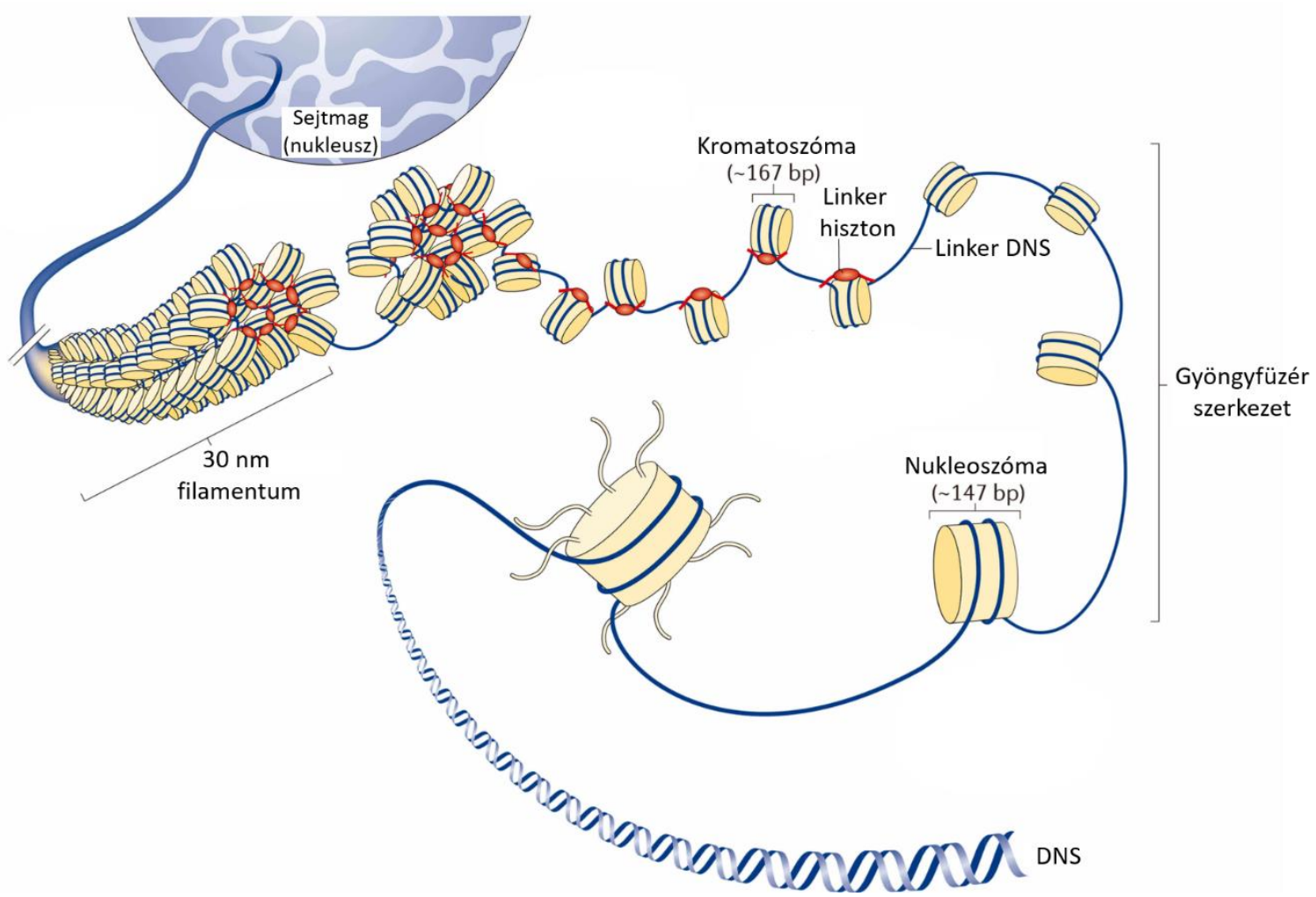

1. ábra. A kromatinszerkezet. Az eukarióta kromatinállomány szerveződési szintjeinek sematikus ábrázolása. Fyodorov és mtsai. alapján (3).

\subsection{HISZTON FEHÉRJÉK ÁLTALÁNOS JELLEMZÖI}

A hiszton fehérjék, melyek lehetővé teszik a DNS magas szintű szervezettségét, meglehetősen konzervált, bázikus aminosavakban gazdag proteinek. Jellemző rájuk az úgynevezett tripartit (három részböl álló) szerkezet: rendelkeznek egy C-terminális, egy centrális és egy $\mathrm{N}$-terminális doménnel. A két terminális domén rendezetlen, míg a centrális domén rendezett szerkezetet vesz fel, mely a core hisztonok esetén az ún. hiszton fold, linker hisztonoknál pedig a globuláris szárnyas hélix domén (winged helix domain, WHD). Már az 1960-as évek óta ismert, hogy a hiszton fehérjék poszttranszlációsan módosulhatnak (4) (2. ábra). Ezek a módosítások (PTM, poszttranszlációs módosítás) bármely hiszton doménen jelen lehetnek, azonban leggyakrabban a két terminális domén módosul. A hiszton PTM-ek és kombinációjuk számos kromatinszerveződést és -funkciót érintő folyamatot befolyásolnak, többek között transzkripciós faktorok kromatinhoz kapcsolódását, internukleoszómális kölcsönhatásokat és a kromatin tömörödését és fellazulását a sejtciklus különböző fázisai során (5). 


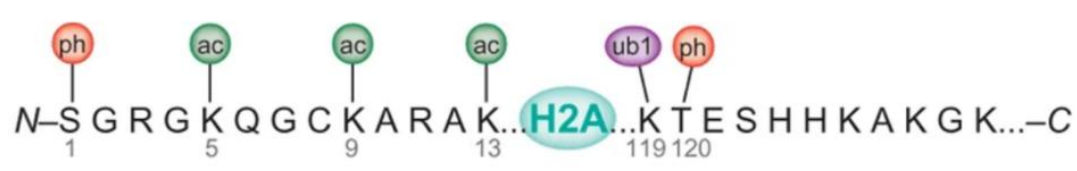

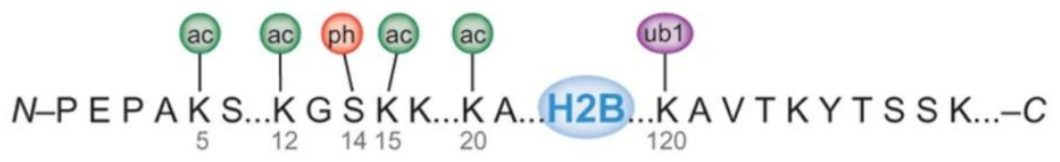

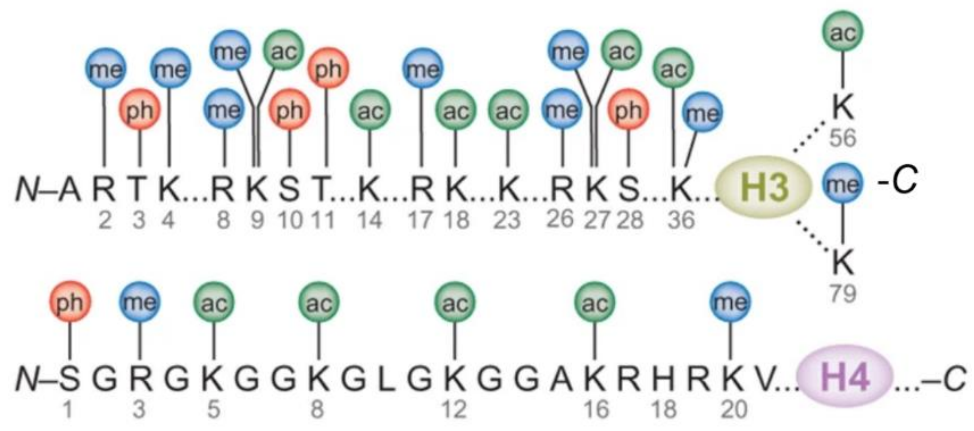

2. ábra. Hiszton módosítások. A legjobban kutatott hiszton módosítások sematikus ábrázolása. $A$ módosítások jelentős része az $\mathrm{N}$-terminális domént érinti. $\mathrm{N}$ : N-terminális domén. $\mathrm{C}$ : $\mathrm{C}$-terminális domén. Ac: acetiláció. Me: metiláció. Ph: foszforiláció. Ub: ubikvitináció. A globuláris doméneket a színes ellipszisek jelentik (6).

A kanonikus hisztonokat kódoló gének jellemzően sok kópiával rendelkeznek, és csoportosan (ún. klaszterekben) helyezkednek el a genomban. Ezek a gének a sejtciklus S-fázisa alatt íródnak át $(7,8)$, hiszen ekkor játszódik le a DNS szintézis is, amelyhez szükség van hiszton utánpótlásra. Humán és egér (Mus musculus) sejtekben egy nagyobb és két kisebb hiszton klaszter található meg (9), míg a Drosophila melanogaster genom egyetlen hiszton lókusszal rendelkezik, ahol minden kanonikus hiszton fehérje génje körülbelül 100 kópiában van jelen (10) (3. ábra). A kanonikus hiszton génekben intronok nem találhatók, és a róluk képződő mRNS molekulák poly-A farokkal nem rendelkeznek. Ezzel szemben 3' végük ún. stem-loop szerkezetet vesz fel, amely a többsejtü állatvilágban konzervált, és az mRNS transzlációjához, illetve az S-fázist követöen a lebomlásához is szükséges (8).

A hiszton fehérjék sokrétüségét tovább növelik a különböző variánsok, melyek a kanonikus hisztonok mellett szintén képesek a kromatinba épülni, és ott változatos feladatokat ellátni. A hiszton variánsokat kódoló gének a kanonikus hiszton génekkel ellentétben általában egyetlen vagy néhány kópiában találhatók 
meg a genomban, a hiszton klasztereken kívül. Ezek, az intronokat is hordozó gének jellemzően a sejtciklus bármely szakaszában (funkciójuknak megfelelően) kifejeződhetnek, és a róluk képződő mRNS poly-A farokkal rendelkezik. A különböző hiszton variánsok többsége szövet- vagy fejlődési stádium-specifikus kifejeződési mintázatot mutat, így számos egyedi funkció rendelhető hozzájuk, melyek végrehajtására a kanonikus hisztonok nem, vagy csak korlátozottan képesek $(11,12)$. A különböző variánsok kromatinba épüléséért más-más hiszton chaperon fehérjék (dajkafehérjék) felelősek: egyetlen hiszton variáns beépítését akár több chaperon is végezheti, a beépülés helyétől és idejétöl függően (13). Mindezen tulajdonságaik alapján a hiszton variánsok fontos résztvevői a génexpresszió finomszabályozásának.

\section{His1} His2B

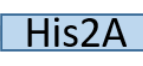

His4 His3

3. ábra. A Drosophila hiszton lókusz (részlet). Az öt kanonikus hiszton gén kb. 100 kópiában, 5 kb méretủ ismétlődő egységekben helyezkedik el a második kromoszóma bal karján (2L). Az ábra egy hiszton génegységet mutat. Flybase alapján (14).

\subsection{LINKER HISZTONOK ÉS KAPCSOLATUK A NUKLEOSZÓMÁVAL}

A linker hisztonok a core hisztonokhoz hasonlóan bázikus, tripartit szerkezettel rendelkező fehérjék, azonban a core hisztonoknál jóval kisebb mértékű konzerváltságot mutatnak $(15,16)$. Ezt főként a két terminális domén változatossága okozza, míg a centrális globuláris domén esetén a legalacsonyabb a variancia az egyes fajok között. Ez a legjobban jellemzett domén, amely a nukleoszómával való kölcsönhatásért felelős, és a nukleoszómába be- és/vagy kilépő DNS-hez kapcsolódik. A globuláris domén önmagában elegendő a nukleoszóma megkötéséhez $(17,18)$, azonban a másodlagos kromatinszerkezet stabilizálásában a C-terminális domén is részt vesz, mely DNS-sel kapcsolódva másodlagos szerkezeteket vesz fel (19-21). Ezzel szemben az N-terminális domén nem szükséges a nukleoszóma kötéshez, azonban befolyásolja a linker hiszton affinitását a kromatinhoz, míg hiányában a fehérje több, nem kromatin-specifikus interakciót hoz létre (22). A rendezetlen $\mathrm{N}$-terminális bázikus aminosavai szintén 
vesznek fel rendezett szerkezetet a DNS-sel kölcsönhatva (alfa-hélix), amelyröl feltételezhető, hogy a globuláris domén nukleoszómához kötődését stabilizálja (23). A H1-nukleoszóma kölcsönhatás mikéntjére több modell is létezik: ismert kristály struktúra és számítógépes modellek alapján a $\mathrm{H} 1$ ún. on-dyad (a nukleoszóma diád tengelyéhez képest közép pozícionált) és off-dyad (a nukleoszóma diád tengelyéhez képest aszimmetrikusan kötődő) módon képes a nukleoszómához kapcsolódni. Különbözö fajokból származó $\mathrm{H} 1$ variánsok vizsgálata azt sugallja, hogy a kötési mód H1 típusra jellemző. Példaként, a csirke (Gallus gallus domesticus) H5 linker hiszton fehérje globuláris doménjével összerendezett nukleoszóma kristályszerkezeti képe alapján a $\mathrm{H} 5$ on-dyad kapcsolódást mutat, és mindkét linker DNS-sel kapcsolatban áll (24) (4A. ábra). Ezzel szemben a Drosophila melanogaster kanonikus $\mathrm{H} 1$ fehérje kötési módja off-dyad, és az egyik linker DNS-sel kapcsolódik, míg a másikkal nem, vagy csak gyengén (4B-C. ábra). Kísérletek azt is igazolták, hogy a nukleoszóma-H1 kötődés bár megtörténik, de gyengébb a H1 C-terminális hiányában, melynek két meghatározott régiója (CTD 119-125 és CTD 164-174) szükséges a megfelelő kötés kialakításához (25).
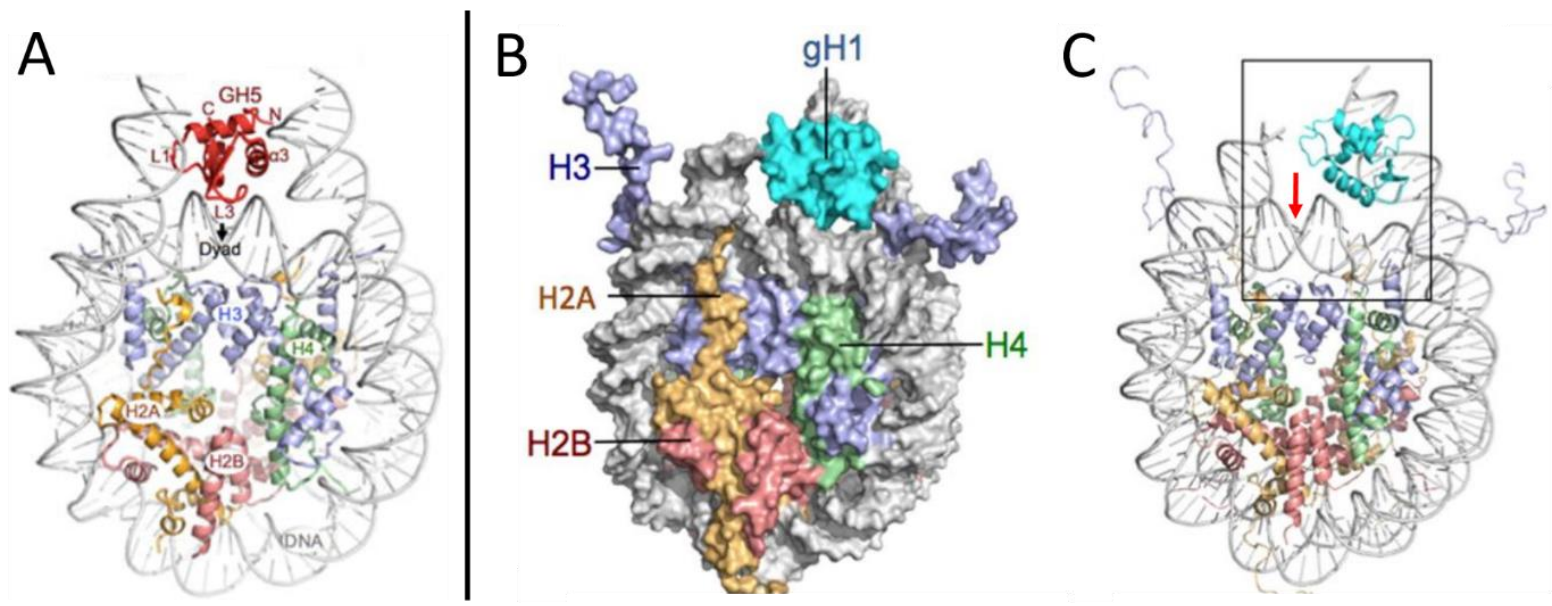

4. ábra. Linker hisztonok on- és off-dyad kötési módja. A) A csirke H5 linker hiszton globuláris doménje (GH5) on-dyad kötési móddal kapcsolódik a nukleoszómához (24). B-C) A Drosophila melanogaster $\mathrm{H} 1$ globuláris doménje ( $\mathrm{gH} 1$ ) off-dyad módon kapcsolódik a nukleoszómához (25). A B) ábra felszín, a C) ábra szalag modellen mutatja be az off-dyad kötést (piros nyíl: dyad). 


\subsection{LINKER HISZTONOK SZEREPE A TRANSZKRIPCIÓ SZABÁLYOZÁSÁBAN}

A linker hisztonok számos olyan funkcióval rendelkeznek, amelyek a kromatin állapotának módosulásához vezetnek. A linker hisztonokra sokáig úgy tekintettek, mint a transzkripció általános represszoraira, melyet több kísérlet is alátámasztott. Herrera és mtsai kimutatták, hogy a $\mathrm{H} 1$ fehérje jelenléte a nukleoszómán gátolhatja a $\mathrm{H} 3$ acetilációját az által, hogy fizikailag akadályozza meg a PCAF (p300/CBP-associated factor) acetil-transzferáz hozzáférését a H3-hoz (26). Közismert, hogy a core hisztonok acetilációja a transzkripciót pozitívan szabályozza $(27,28)$, míg az aktív géneken általában nem található $\mathrm{H} 1$ fehérje (29). Drosophila ivarvonal őssejtekben a $\mathrm{H} 1$ hisztonnak fontos szerepe van az őssejt identitás megörzésében a H4 hiszton K16-os pozíciójú acetilációjának szabályozásával. Ezekben a sejtekben a H1 hiánya H4K16 hiperacetilációt okoz, amely a bam differenciálódási faktor transzkripciójának aktiválásán keresztül az őssejtek korai differenciálódásához vezet (30). Egér embrionális őssejteken végzett kísérletek azt is kimutatták, hogy a $\mathrm{H} 1$ fehérje akadályozhatja egy másik, transzkripciót aktiváló jel, a H3K4me3 módosítás megjelenését (31). A H1 linker hiszton továbbá részt vesz a heterokromatin régiók kialakításában is, és a Su(var)39 hiszton-metiltranszferáz toborzásával szabályozza a H3K9me3 transzkripciósan represszív hisztonmódosítás megjelenését a kromatinon (32). Egyes források szerint a $\mathrm{H} 1$ nem általános transzkripció gátló fehérje, azonban a heterokromatin kialakításában játszott szerepének kiemelt fontossága van a transzpozábilis elemek (TE, transzpozonok) átírásának szabályozásában $(33,34)$. A H1 hiszton fizikai és biológiai kölcsönhatása a transzpozon RNS-ek kifejeződését gátló, illetve a lebomlásukat közvetítő PIWI-rendszer piwi fehérje komponensével is ismert (35), így elmondható, hogy a $\mathrm{H} 1$ linker hiszton részt vesz a genom stabilitásának megőrzésében is. 


\subsection{LINKER HISZTON VARIÁNSOK}

A core hisztonokhoz hasonlóan a linker hisztonok is számos variánssal rendelkeznek, melyek között van szomatikus (testi sejtekben kifejeződő) és ivarvonal-specifikus is. Néhány faj egészen nagyszámú alternatív $\mathrm{H} 1$ fehérjével rendelkezik, példaként az emberben és egérben 11-11, a Caenorhabditis elegans fonálféregben pedig nyolcféle H1 változat található meg. Vannak azonban olyan egyszerü élölények, mint az Aspergillus nidulans fonalas gomba vagy a Saccharomyces cerevisiae élesztőgomba, amelyek csupán egyféle H1 fehérjével rendelkeznek.

A különböző variánsok más-más funkciót látnak el, változatos az affinitásuk a kromatinhoz, és eltérő mértékben kondenzálják azt. Humán sejtekben végzett kísérletek arra utalnak, hogy a rövidebb C-terminális doménnel rendelkező $\mathrm{H} 1$ variánsoknak a kromatinhoz való affinitása kisebb, és sokkal dinamikusabban cserélődnek a kromatinon (36). Bizonyos variánsok csak heterokromatinban, mások föleg eukromatinban fordulnak elő (36). Vannak olyan H1 változatok, melyek létfontoságú funkciókért felelősek a sejtben. A humán $\mathrm{H} 1.0$ alternatív hisztonnak fontos szerepe van a pluripotens sejtek differenciálódása során a pluripotenciáért felelős gének csendesítésében, mivel hiányában ezek a gének aktívak maradnak, ami késleltetett, rendellenes differenciálódáshoz vezet (37). Ezzel szemben más variánsok szerepe redundánsnak tünik, hiszen hiányukat más alternatív linker hiszton jelenléte képes kompenzálni, így deléciójuk nem jár fenotípussal. $\mathrm{H} 1 \mathrm{c}, \mathrm{H} 1 \mathrm{~d}$ vagy $\mathrm{H} 1 \mathrm{e}$ mutáns egerek a vad típushoz hasonlóan életképesek, fertilisek és normális fejlődést mutatnak, csakúgy, mint a $\mathrm{H} 1 \% / \mathrm{H} 1 \mathrm{c}, \mathrm{H} 1 \% / \mathrm{H} 1 \mathrm{~d}$ vagy $\mathrm{H} 1 \% / \mathrm{H} 1 \mathrm{~d}$ dupla mutánsok. Ilyen esetben a többi szomatikus variáns fehérje szintje megemelkedik és pótolja a depletált hisztont (38). $\mathrm{H} 1 \mathrm{c} / \mathrm{H} 1 \mathrm{~d} / \mathrm{H} 1 \mathrm{e}$ tripla mutáns egerek, melyekben a $\mathrm{H} 1$ tartalom a vad típus 50 \%-ára esik, azonban már embrionális korban elpusztulnak (39). Emlősökben tehát a H1 fehérje szerepe létfontosságú. Ezzel ellentétben a már említett, csak egyetlen linker hisztonnal rendelkező $A$. nidulansban és $S$. cerevisiae-ben a $\mathrm{H} 1$ gén deléciója semmilyen fenotípust nem von maga után $(40,41)$. 


\subsection{PETESEJT- ÉS EMBRIÓSPECIFIKUS LINKER HISZTON VARIÁNSOK}

A H1 variánsok között számos olyan található, amely csak az ivarvonalban és a korai embrionális fejlődés során fejeződik ki. Ezek a fehérjék általában méretüket és aminosav-összetételüket tekintve nagymértékben eltérnek a szomatikus H1 variánsoktól. A gerinctelen tengeri sün (Echinoidea) minden hiszton fehérjéből rendelkezik petesejt- és embrióspecifikus variánssal, melyeket osztódási stádium (CS, cleavage stage) hisztonoknak nevezünk. Ezek a fehérjék, közöttük a CS $\mathrm{H} 1$ részt vesznek a spermium örökítőanyagának dekondenzálásában és a genom gyors szintézisében (42-44). A dél-afrikai karmosbéka (Xenopus laevis) korai fejlődésében szerepet játszó $H 1$ variánsa a $B 4(\mathrm{H} 1 \mathrm{M})$ nevű hiszton fehérje, amely szintén csak petesejtben és a korai embrionális szövetben fejeződik ki, és egészen a gasztrula stádiumig jelen van a fejlődő embrióban $(45,46)$. A zebra dánió (Danio rerio) $\mathrm{H} 1 \mathrm{M}$ linker hiszton variánsa hasonlóképpen a gasztrula stádiumig van jelen a korai embrióban, majd a gasztrulációtól kezdődően a kifejeződési mintázata visszaszorul a primordiális ivarsejtekre, melyekből a fejlődés során az érett ivarsejtek alakulnak ki $(47,48)$. Az egerekben 11 linker hiszton variáns fordul elő, melyek közül a H1FOO a petesejtben kifejeződő alternatív hiszton. H1FOO mRNSátírás a fertilizációt követően már nem történik, azonban az RNS fennmarad az egysejtes embrióállapotig, majd a kétsejtes stádiumtól rohamosan csökken a szintje, és végül felváltják a szomatikus $H 1$ variánsok. A H1FOO elsősorban a H3.3 hiszton variánssal lép kölcsönhatásba, és nem a H3.1 és H3.2 fehérjékkel, melyek a zárt kromatinstruktúra kialakulásában játszanak szerepet. Így a H1FOO az egysejtes embrió lazább kromatinszerkezetéhez járul hozzá. A H1FOO kiütése fokozott H3.1/H3.2 kromatinba épülést eredményez, melynek következtében a DNS replikáció, és így a kétsejtes állapotba lépés is késést szenved, ez azonban a további fejlődést és fertilitást nem befolyásolja $(49,50)$.

\subsubsection{Alternatív linker hiszton fehérje Drosophila melanogaster-ben}

A Drosophila melanogaster-röl sokáig azt feltételezték, hogy egyetlen linker hiszton fehérjével rendelkezik (H1). 2013-ban felfedeztek egy alternatív linker hisztont, amely fehérjeszerkezetét tekintve hasonló, azonban aminosavsorrendjét és méretét tekintve eltérő a $\mathrm{H} 1$ fehérjéhez képest. Ezt a fehérjét a mérete alapján 
BigH1-nek nevezték el, és kimutatták róla, hogy az embrionális fejlődés kezdeti szakaszában tölti be a linker hiszton szerepét (51).

\subsubsection{Drosophila korai embrionális fejlödés}

A Drosophila embrió fejlődése a fertilizációt követő 13 szinkronizált magi osztódással kezdődik. Ez a folyamat meglehetősen gyors, az osztódásokat csak DNS replikáció (S-fázis, mely alig több mint 3 perc, (52)) és mitózis (M-fázis) jellemzi. A 9. ciklus során a magok többsége az embrió felszíne felé vándorol, és egy rétegben helyezkednek el, kialakítva a szincíciális blasztodermát. Ezt követően a magi ciklusok kismértékü, de fokozatos lassulást mutatnak, a 14. ciklus időtartama pedig meghaladja az egy órát. Ebben a ciklusban minden felszínre vándorolt mag és a környezetükben lévő citoplazma körül kialakul a plazmamembrán, így valódi sejtek jönnek létre. Ezt a folyamatot cellularizálódásnak nevezzük, melynek során a szincíciális blasztoderma embrióból celluláris blasztoderma embrió lesz. A celluláris blasztoderma embrió ezután a gasztruláció fázisába lép, melynek során kialakulnak a csíralemezek (53) (5. ábra).

A fejlődő embrióban nem csupán morfológiai változások történnek. A fertilizációt követően az embrionális genomról mRNS szintézis nem történik, így a fejlödést az anyától származó géntermékek irányítják. A továbbiakban azonban az utód önálló fejlődéséhez szükségessé válik a genom aktivációja is. Ezt a folyamatot maternáliszigótikus tranzíciónak (MZT) nevezzük, amely során az anyai géntermékek fokozatosan lebomlanak, és átadják helyüket a genomról termelődőknek. Már a 8. ciklustól kezdve kimutatható bizonyos zigótikus gének transzkripciós aktivitása, majd az aktív gének száma a ciklusok elörehaladtával fokozódik. A folyamat a 14 . ciklus végére kiteljesedik, és a cellularizációt követő fejlődési stádiumokat már zigótikus géntermékek vezérlik $(54,55)$. 


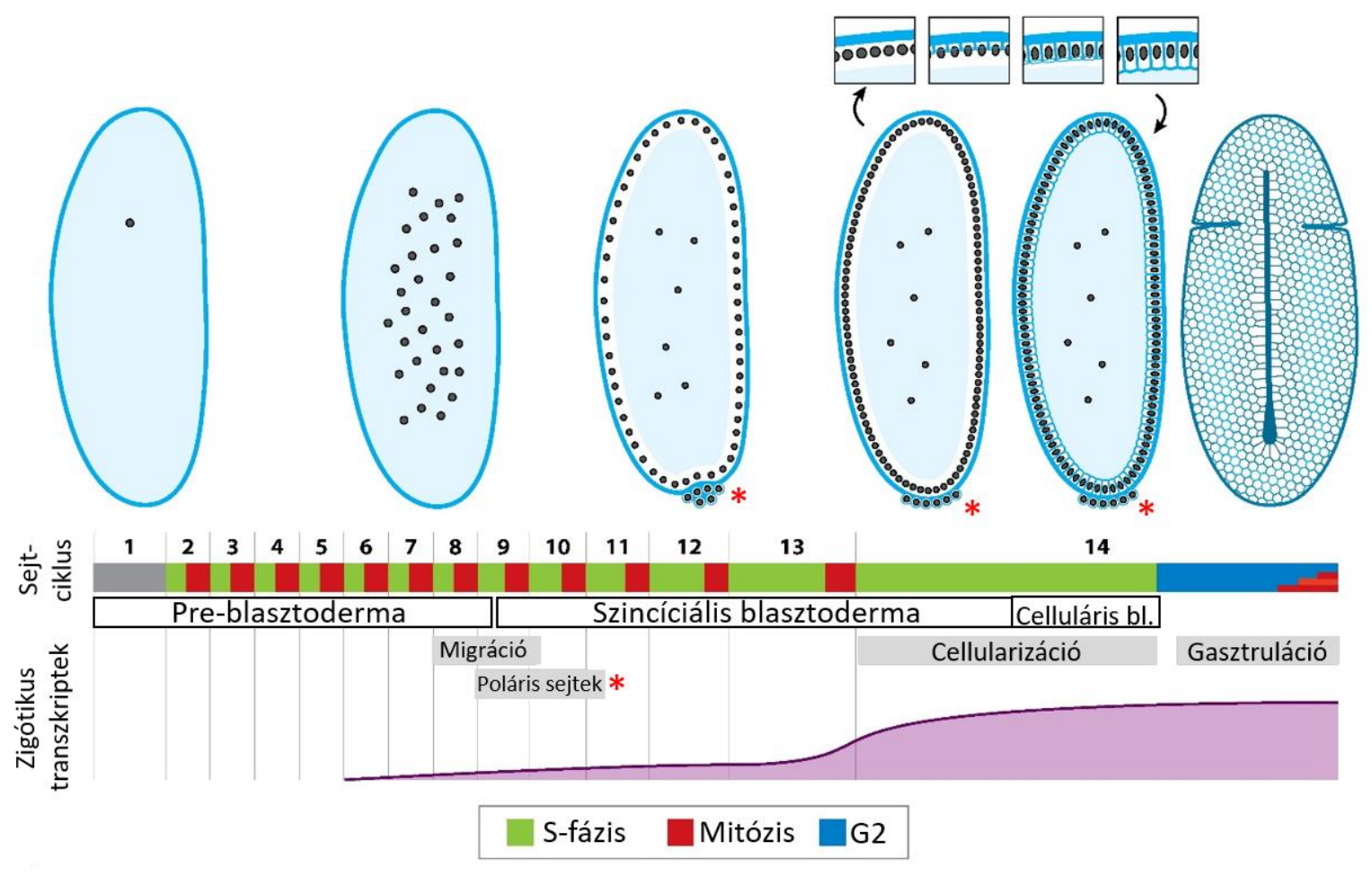

5. ábra. Drosophila korai embrionális fejlődés. A megtermékenyitést követően az embrióban 13 gyors magi osztódás zajlik le, és a magok az embrió felszínére vándorolnak, kialakítva a szincíciális blasztodermát. A 14. ciklus során kialakulnak az egyedi sejtmagok (cellularizáció folyamata), majd megkezdődik a gasztruláció. A cellularizációval egyidőben nagymértékben megnő a transzkripciós aktivitás a genomról (zigótikus genomaktiváció) (54). A piros csillagok az ivarvonal sejtek (poláris sejtek) elhelyezkedését jelzik.

\subsubsection{A BigH1 linker hiszton szerepe a korai fejlődésben}

A korai fejlődési szakaszokra jellemző BigH1 fehérjét a korábban CG3509ként ismert gén kódolja, amely a harmadik kromoszóma jobb karján (3R) helyezkedik el. A BigH1 más petesejt-specifikus linker hisztonokhoz hasonlóan nagyobb méretü, mint a kanonikus $\mathrm{H} 1$, nevét is erröl a tulajdonságáról kapta. A BigH1 fehérje nagyobb mérete a meglepően hosszú, 103 aminosavból álló $\mathrm{N}$ terminális régiójából ered, amely a kanonikus $\mathrm{H} 1$-el szemben nagy arányban tartalmaz savas természetü glutamát $(E)$ és aszpartát $(D)$ aminosavakat. A teljes fehérjét 353 aminosav építi fel, mérete körülbelül $38,6 \mathrm{kDa}$, és szerkezetileg a többi linker hisztonra is jellemző tripartit struktúrával rendelkezik.

2013-ban a BigH1-et a korai embriógenezisre jellemző egyetlen linker hisztonként írták le, amely a cellularizációt megelőző osztódási ciklusokban (0-2 
órával a fertilizációt követően) mRNS-ként és kromatinhoz egyenletesen kötődő fehérjeként is nagyon abundáns. A cellularizációt követöen rohamosan lecsökken a szintje, és fokozatosan kicserélödik a szomatikus $\mathrm{H} 1$ fehérjére a kromatinon (51). A $\mathrm{BigH} 1$ fehérje csak a primordiális ivarvonal őssejtekben (PGC, primordial germ cell) marad fenn (51), melyekben a zigótikus genomaktiváció késleltetve történik meg a transzkript elongációért felelős RNS polimeráz II Ser2 foszforilációjának repressziója miatt $(55,56)$ (6. ábra).

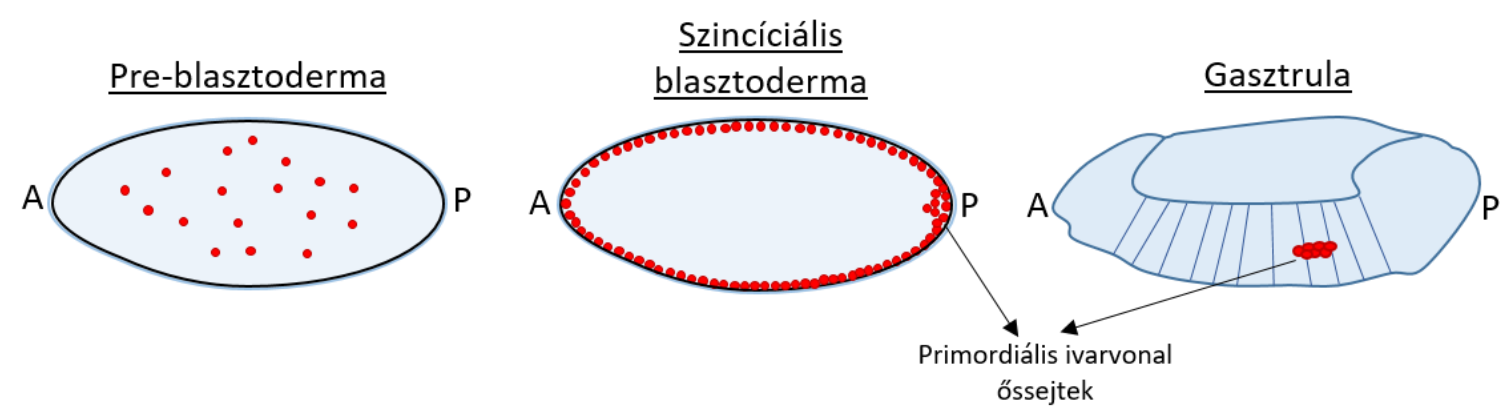

6. ábra. A BigH1 fehérje kifejeződése embrionális fejlődés során. Piros szín jelöli a BigH1 fehérjét tartalmazó sejtmagokat. A gasztrula stádiumban a BigH1 csak a primordiális ivarvonal őssejtekben marad fenn, a gasztrulálódó embrió többi sejtjében a H1 átveszi a szerepét.

A BigH1 mRNS és fehérje expresszió a felnőtt Drosophila egyedek hím- és nőstény ivarvonalában is fennmarad. A nőstények petefészkeiben az oocitában, és a késői stádiumokban az oocitával szomszédos dajkasejtekben is jelen van, míg a hímivarvonalban az össejtekben és a differenciálódott spermatocitákban fejeződik ki (51). Utóbbi esetben ismert, hogy a BigH1 a Bam (bag of marbles) fehérjével együtt kettős negatív visszacsatolással szabályozzák a spermatociták differenciációját (57).

Kezdetben a BigH1 linker hisztont a fejlődéshez elengedhetetlen fehérjének gondolták, hiszen a BigH1 funkcióvesztéses mutáns állatok még a korai embriógenezis során elpusztultak, és súlyos mitótikus hibákat, DNS-károsodást és korai zigótikus genomaktivációra utaló jeleket mutattak. Ezen fenotípusok megjelenése miatt azt feltételezték, hogy a BigH1 fehérje szükséges ahhoz, hogy megakadályozza a genom idő előtti aktivációját, és addig a kromatint represszált állapotban tartsa (51). Később azonban bebizonyosodott, hogy a fenotípust egy 
háttérmutáció okozhatta, és a Drosophila fejlödése a BigH1 hiányában is megfelelöen zajlik, igaz, hogy ebben az esetben a BigH1 hiányát eddig ismeretlen módon a szomatikus H1 kompenzálja $(58,59)$.

Így tehát a BigH1 linker hiszton embrionális fejlödésben betöltött pontos szerepe továbbra is ismeretlen. A dolgozatban bemutatott kísérletsorozatokkal arra kerestem a választ, hogy milyen nem letális fenotípusok figyelhetők meg a BigH1 fehérje hiányában, ezek a fenotípusok milyen funkciókkal kapcsolhatók össze, és végül összefoglalva: miért alkalmasabb linker hiszton a korai fejlődés során a nem esszenciális BigH1, mint a szomatikus $\mathrm{H} 1$ ? 


\section{CÉLKITÜZÉSEK}

A linker hiszton fehérjék többsejtü élölényekben nélkülözhetetlenek a fejlődéshez és az általános génszabályozáshoz szükséges kromatinszerkezet kialakításához. A legtöbb többsejtú állatban az embrionális fejlödés kezdeti szakaszában, tehát a fejlődés legelső és legfontosabb lépései során egy alternatív linker hisztonra van szükség, amely a maternális-zigótikus tranzíció folyamán kanonikus $\mathrm{H} 1$ fehérjére cserélődik. A linker hisztonok vizsgálatára kevés alkalmas modell létezik, hiszen ezek a fehérjék több variánssal rendelkeznek, melyeknek a funkciója sok esetben redundáns. Emiatt választásunk a Drosophila melanogaster (ecetmuslica) modellállatra esett, hiszen az ecetmuslica csupán két linker hiszton fehérjével rendelkezik, a kanonikus H1-gyel és az ivarvonal- és embrióspecifikus BigH1-gyel.

Csoportunkban a BigH1 fehérje embrionális fejlödésben betöltött szerepét kívántuk vizsgálni, illetve arra a kérdésre választ kapni, hogy funkcionálisan miként tér el a kanonikus $\mathrm{H} 1$ linker hisztontól. Ehhez olyan mutáns Drosophila vonalakat hoztunk létre, amelyekben a BigH1 fehérje kódoló szakaszát BigH1-H1 kiméra fehérjékre cseréltük. Az egyes kimérákban a BigH1 linker hiszton három doménjének valamelyikét vagy mindegyikét kanonikus $\mathrm{H} 1$ fehérje domének helyettesítik, mely lehetőséget adott a két linker hiszton fehérje doménjeinek funkcionális összehasonlítására.

Az én feladatom elsősorban a BigH1 és $\mathrm{H} 1$ fehérjék által kialakított kromatinszerkezet különbségeinek vizsgálata volt, melyhez a következő kérdések megválaszolását tủztük ki:

1. Hogyan befolyásolja a kromatin hozzáférhetőségét és a nukleoszómális DNS hosszát a kanonikus $\mathrm{H} 1$ jelenléte a korai embrionális szövetben?

2. Befolyásolja a nukleoszómák, illetve kromatoszómák stabilitását, hogy BigH1 vagy $\mathrm{H} 1$ a hozzájuk kapcsolódó linker hiszton?

3. Tapasztalható-e génexpressziós változás attól függően, hogy $\mathrm{BigH} 1$ vagy $\mathrm{H} 1$ linker hiszton található a kromatinállományban? 
4. Továbbá feladatom volt egy BigH1 fehérjét nem kifejező nullmutáns (NULL) és egy foszforilálódásra nem képes BigH1 fehérjét kifejező mutáns $(P O)$ létrehozására alkalmas plazmid tervezése és előállítása. 


\section{ANYAGOK ÉS MÓDSZEREK}

\subsection{DROSOPHILA VONALAK ELÖÁLLÍTÁSÁHOZ SZÜKSÉGES PLAZMIDOK LÉTREHOZÁSA}

\subsubsection{BigH1 nullmutáns ( $d B i g H 1^{N U L L}$ ) szekvencia klónozása}

\subsubsection{Plazmid megtervezése}

A nullmutáns állatok létrehozásához olyan plazmidot terveztem, amelyben a BigH1 kódoló szekvenciáját loxP helyek közé illesztett mCherry fluoreszcens markerre cseréltem, viszont az UTR-ek érintetlenek maradtak. Így az állatokban nem termelődik BigH1 fehérje, azonban az mCherry marker annak megfelelő időben és mintázatban fejeződik ki, így jól követhető a fehérje expressziós mintázata fluoreszcens mikroszkópiával, illetve a loxP helyek miatt Cre rekombináz segítségével bármikor eltávolítható az mCherry szekvencia a genomból. A konstrukció elkészítéséhez egy olyan plazmidot használtam fel, amelyet csoportunkban készítettünk, és a vad típusú BigH1 fehérjét hordozza mCherry taggel ellátva (pUC18 PvuDel dBigH1 mCh).

\subsubsection{Primertervezés Szekvencia és Ligálás Független Klónozáshoz (SLIC)}

A klónozást Szekvencia és Ligálás Független Klónozás (SLIC) technikával végeztem, mely lehetővé teszi több DNS molekula összekapcsolását egyszerü módon (60). A módszer alapja, hogy az összeépítendő DNS molekulákat PCR-rel sokszorozzuk. Ehhez olyan primereket alkalmazunk, amelyek körülbelül 25-25 bázispár átfedésben vannak mindkét molekula összekapcsolni kívánt végeivel, így a létrejövő PCR termékek végei is átfednek majd. Az amplifikált DNS molekulákat méretüktől függő arányban összekeverjük, majd T4 polimerázzal kezeljük, aminek dNTP hiányában exonukleáz aktivitása van, így 25 bp túlnyúló végeket hozunk létre. Az emésztett DNS-t azonnal transzformáljuk, és a plazmid összeépülése már a baktériumban történik homológ rekombinációval. A módszer követelményeinek megfelelö primereket terveztem, melyek átfednek a loxP és az mCherry szekvenciájával is (loxP mCh Fw és loxP mCh Rev primerek), a BigH1 5' vagy 3' UTR-ével és a loxP hellyel (loxP 3'UTR és loxP 5'UTR primerek), illetve két olyan 
primert, amik az origóban vannak és egymással részlegesen átfednek (PSLIC F és PSLIC R). A felhasznált primerek szekvenciáját az 1. Függelék táblázat tartalmazza.

\subsubsection{PCR reakciók és fragmentum izolálás}

A tervezett primerek segítségével három PCR-t végeztem a pUC18 PvuDel dBigH1 mCh plazmidon, így három szakaszt amplifikálva, amiket később SLIC-kel építettem össze. Minden reakcióban Q5 polimerázt alkalmaztam az inszertek nagy mérete, illetve a fidelitás fontossága miatt. A következő beállitásokat használtam az egyes reakciókhoz (1. táblázat):

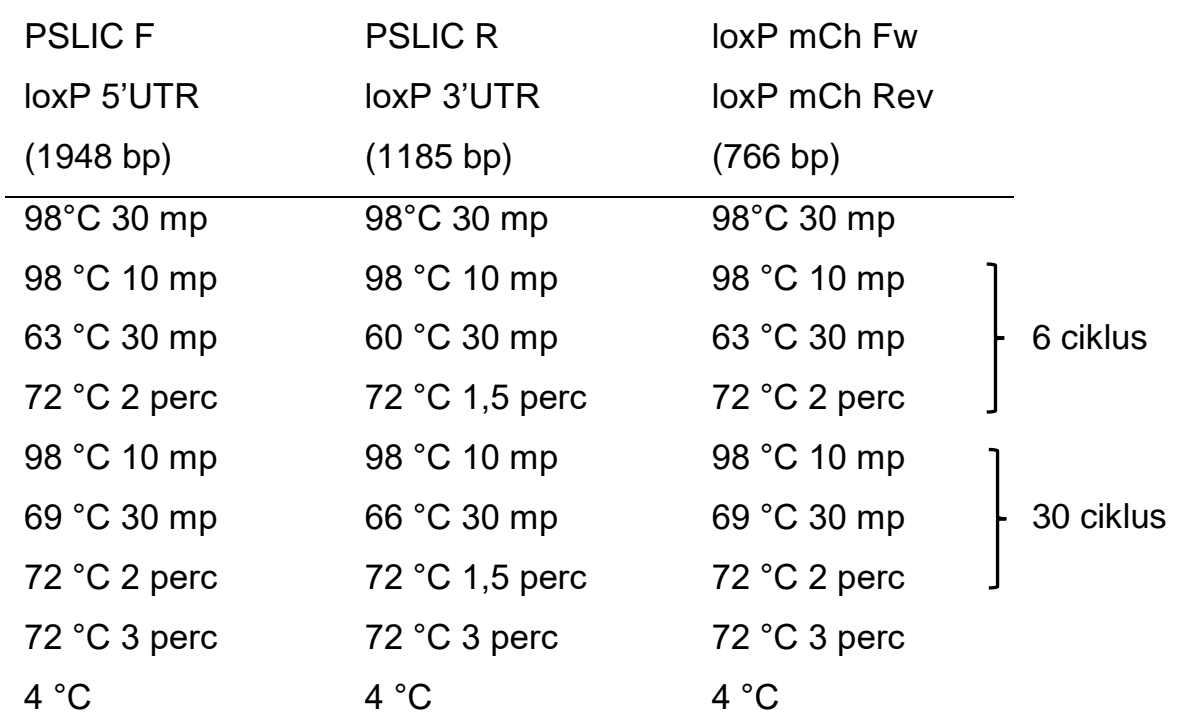

1. táblázat. PCR programok a BigH1 NULL mutáns szekvenciát hordozó plazmid előállitásához szükséges DNS fragmentumok amplifikálásához.

A PCR reakciók sikerességét és a keletkezett termékek méretét $1 \%$-os agaróz gélen futtatva ellenőriztem, majd Biostep UV transilluminator készülékre helyezve a gélt UV fénnyel $(312 \mathrm{~nm})$ láthatóvá tettem a DNS mintákat és pengével kivágtam öket, ezt követően Nucleospin Gel and PCR Clean-up Kittel (MachereyNagel) izoláltam, a gyártó útmutatása szerint. A DNS koncentrációját Nanodrop 2000-rel mértem le. 


\subsubsection{SLIC reakció és transzformálás}

A reakciót $10 \mu$ l végtérfogatban mértem össze, amelyhez $0,2 \mu \mathrm{l}$ T4 polimerázt (Thermofisher Scientific) és $1 \mu \mathrm{l} 10 x \mathrm{G}$ puffert (10 mM Tris- $\mathrm{HCl}(\mathrm{pH} 7.5), 10 \mathrm{mM}$ $\mathrm{MgCl}$, $50 \mathrm{mM} \mathrm{NaCl}, 0.1 \mathrm{mg} / \mathrm{ml} \mathrm{BSA}$ ) (Thermofisher Scientific) adtam. A három DNS mintát a méretükböl adódóan 1:2:3 moláris arányban mértem be a reakcióba, majd kiegészítettem $10 \mu$ végtérfogatra. 2,5 percig $25^{\circ} \mathrm{C}$-on, majd 10 percig jégen inkubáltam, ezt követöen pedig a teljes reakcióelegyet 2T1 baktérium sejtekbe transzformáltam. A minta hozzáadását követően a sejteket 30 percig jégen tartottam, majd hősokkoltam $90 \mathrm{mp}$-ig $42^{\circ} \mathrm{C}$-on. Hösokk után $1 \mathrm{ml}$ YTB tápoldatot és $7 \mu \mathrm{l}$ glükózt adtam a sejtekhez, és további 1 órát inkubáltam $37^{\circ} \mathrm{C}$-on. Ezt követően a sejteket centrifugálással kiülepítettem (13000 rpm, 1 perc) és ampicillin tartalmú YTB agar lemezekre szélesztettem (5 g élesztö kivonat, $5 \mathrm{~g} \mathrm{NaCl}, 10 \mathrm{~g}$ tripton, $2 \%$ agar 1 liter oldathoz).

\subsubsection{Plazmid preparálás}

A lemezekröl folyékony YTB ( $5 \mathrm{~g}$ élesztő kivonat, $5 \mathrm{~g} \mathrm{NaCl}, 10 \mathrm{~g}$ tripton 1 liter oldathoz) tápoldatba oltottam a telepeket, és éjszakán át növesztettem $37^{\circ} \mathrm{C}$-on. Másnap 1,5 ml baktérium kultúrát tiszta Eppendorf csőbe mértem, centrifugálással kiülepítettem a sejteket (13000 rpm, 1 perc), és eltávolítottam a tápoldatot. A baktérium pelletet felszuszpendáltam $100 \mu \mathrm{l}$ Puffer I-ben $(25 \mathrm{mM}$ Tris pH 8, $50 \mathrm{mM}$ glükóz, $10 \mathrm{mM}$ EDTA, $5 \mu \mathrm{g} / \mathrm{ml}$ lizozim) és 5 percig inkubáltam $25{ }^{\circ} \mathrm{C}$-on. Hozzáadtam $200 \mu \mathrm{l}$ Puffer II-t ( $1 \%$ SDS, $200 \mathrm{mM} \mathrm{NaOH}$ ), és addig forgattam a csövet, amíg fel nem tisztult a minta, majd 5 percig inkubáltam jégen. Ezt követöen hozzáadtam $150 \mu \mathrm{l}$ Puffer III oldatot (3 M K-acetát pH 4.8, 11.5\% ecetsav), és újabb 5 percre jégre tettem, majd a csapadékot centrifugálással ülepítettem (13000 rpm, 5 perc). A felülúszót tiszta Eppendorf csőbe tettem úgy, hogy a csapadékból semmi ne kerüljön át, a mennyiségéhez mérten $1 / 2$ térfogat DNS dializálóval telített fenolt és $1 / 2$ térfogat kloroform:izoamilalkohol (24:1) keverékét adtam hozzá, majd erősen vortexeltem 1 percig. A mintákat centrifugáltam (13000 rpm, 5 perc), majd a felső fázist új Eppendorf csőbe helyeztem és a mennyiségéhez képest két térfogatnyi $96 \%$-os etanolt adtam hozzá. Rövid vortexelést követöen 30 percre $-80{ }^{\circ} \mathrm{C}$-os 
hütőbe helyeztem, majd kiülepítettem a csapadékot centrifugálással (13000 rpm, 5 perc). Eltávolítottam a felülúszót, és mostam a csapadékot $1 \mathrm{ml} 70 \%$-os $4{ }^{\circ} \mathrm{C}$-os etanollal (13000 rpm, 5 perc). Ezt követően vákuum pumpával szárítottam be a csapadékot, és feloldottam RNáz tartalmú TE pufferben (10 mM Tris pH 7.5, 1 mM EDTA, $1 \mathrm{mg} / \mathrm{ml}$ RNáz). Tesztemésztéssel megbizonyosodtam arról, hogy a plazmid tartalmazza a kívánt módosításokat.

\subsubsection{Beépítés $\mathrm{pTZ}$ vektorba és előkészítés injektálásra}

A módosított BigH1 szekvenciát a leírt módon létrehozott plazmidból olyan módosított pTZ vektorba klónoztam, amelyet csoportunkban készítettünk és már tartalmazta a BigH1 gén genomi környezetét, a homológ karokat. Ehhez az elkészült, BigH1 nullmutáns szekvenciát hordozó plazmidot és a módosított pTZ vektort BstZ17I és Bglll restrikciós enzimekkel (Thermofisher Scientific) emésztettem, majd a korábban ismertetett módon gélböl izoláltam a szükséges fragmentumokat (1156 bp méretủ szakasz a BigH1 nullmutáns szekvenciát hordozó plazmidból, és 5994 bp hosszúságú szakasz a módosított pTZ vektorból). T4 ligázt (Thermofisher Scientific) használva (1:6 inszert:vektor arányt alkalmazva, $16{ }^{\circ} \mathrm{C}$-on, éjszakán át) a pTZ vektoron található homológ karok közé illesztettem a BigH1 UTR-ek által határolt mCherry-loxP szekvenciákat. A transzformálást és plazmid preparálást a korábban leírt módon végeztem, majd Xhol és Bglll enzimekkel történő restrikciós emésztéssel kimutattam, hogy sikeres volt a kívánt plazmid létrehozása. Injektáláshoz nagy mennyiségủ és jó minőségủ plazmid DNS-re van szükség, amit Qiagen Plasmid Midi Kit segítségével, a gyártó által megadott protokollt követve izoláltam, majd a visszanyert plazmidot injektáló pufferben oldottam fel $\left(5 \mathrm{mM} \mathrm{KCl}, 0.1 \mathrm{mM} \mathrm{KH}_{2} \mathrm{PO}_{4}, \mathrm{pH}: 7.8\right)$, és $500 \mathrm{ng} / \mu \mathrm{l}$ koncentrációban készítettem elő injektálásra, amit az SZBK Drosophila Injektáló laborjában végeztek. A létrehozott Drosophila vonalra a továbbiakban NULL mutánsként hivatkozom. A klónozás menetét a 7. ábra mutatja be. 
A

1. pUC18 PvuDel dBigH1 mCh plazmid

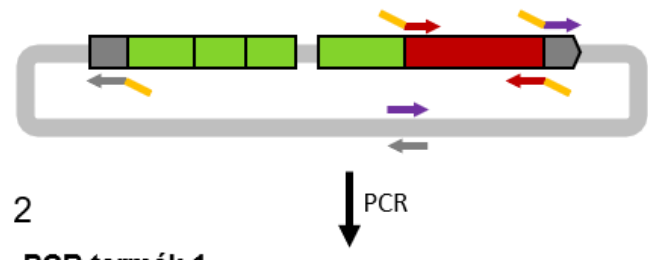

PCR termék 1.

PSLIC F

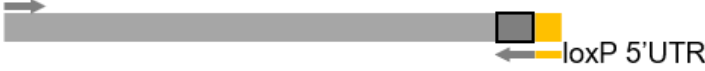

PCR termék 2.

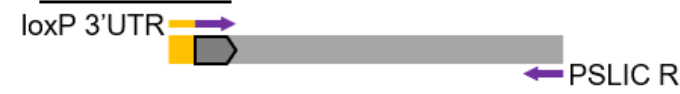

PCR termék 3.

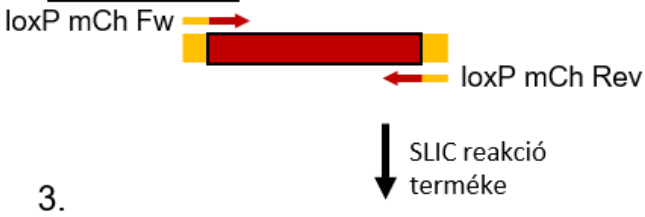

3.

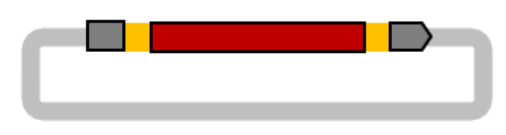

B

1. pUC18 3F dBigH1 loxP mCherry plazmid
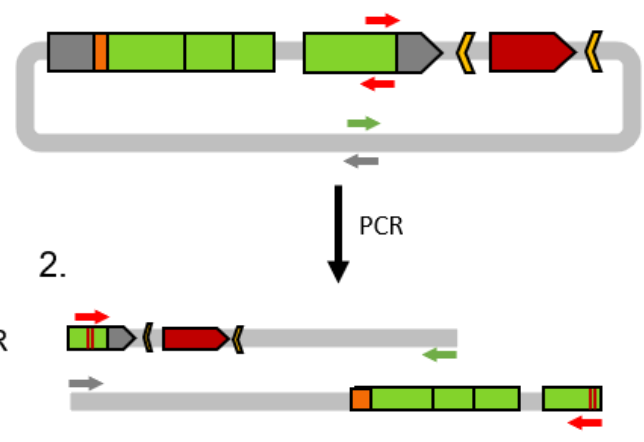

3.

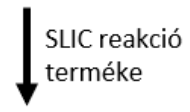

$\downarrow \begin{aligned} & \text { SLIC reakció } \\ & \text { terméke }\end{aligned}$
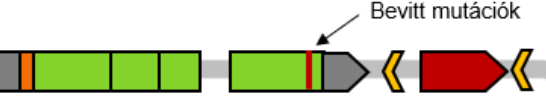

C
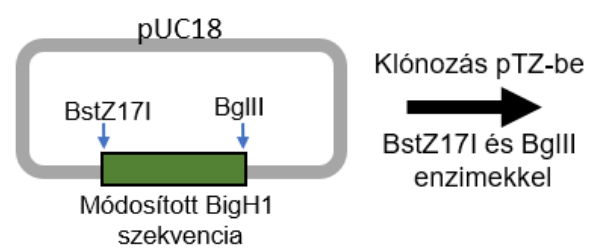

enzimekkel

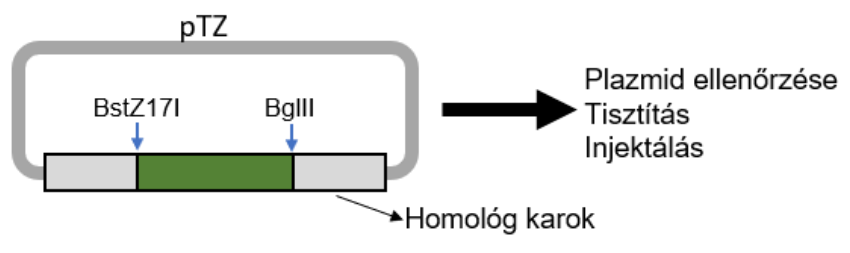

UTR-ek

dBigH1 gén

mCherry marker

loxP szekvencia

3x FLAG tag

$\rightleftarrows$ Mutációkat hordozó primerek

7. ábra. NULL és $\boldsymbol{P O}$ mutáns allélok klónozási sémája. A) NULL BigH1 deléciós mutáns Drosophila törzs létrehozására alkalmas módosított szekvencia elkészítésének sémája. $A / 1) A$ pUC18 PvuDel dBigH1 mCh plazmidról a nyilakkal jelölt primerpárokkal az $A / 2$ ) részen jelölt szakaszokat amplifikáltam, melyek az A/3) ábrán jelölt módon épültek össze a SLIC reakció során. B) PO BigH1 mutáns Drosophila vonal létrehozására alkalmas módosított szekvencia elkészítésének sémája, az S287/288 plazmid elkészítését bemutatva. B/1) A pUC18 3F dBigH1 loxP mCherry plazmidról a nyilakkal jelölt primerpárokkal a $\mathrm{B} / 2$ ) részen jelölt szakaszokat amplifikáltam, melyek a $B / 3)$ ábrán jelölt módon épültek össze a SLIC reakció során. C) A módosított BigH1 szekvencia klónozása pUC18 vektorból a homológ karokat hordozó pTZ vektorba, BstZ17I és Bglll restrikciós enzimek felhasználásával. 


\subsubsection{BigH1 foszforilációs mutáns ( $d B i g H 1^{3 x F L A G:: P Q}$ ) szekvencia klónozása}

\subsubsection{Plazmid és primerek megtervezése}

A BigH1 fehérjében négy foszforilációs helyet találtunk Zhai és mtsai (61) munkája alapján. Ezeknek pontos pozíciója S287, S288, S299 és S331 (Cterminális). A mutáns előállításához mind a négy szerin aminosavat alaninra cseréltem SLIC reakció segítségével. Ehhez olyan primereket terveztem, amelyek már a mutáns formában hordozzák a kérdéses aminosavat kódoló szekvenciát (S287/288A F és R, S299A F és R, S331A F és R, 1. Függelék táblázat. A forward és reverz primerek egymással átfednek a SLIC-nek megfelelő módon). A mutációkat egy olyan plazmidon hoztam létre, amelyet korábban a csoportunkban állítottak elö, és a 3x FLAG tagelt BigH1 gént és a dsRed markert hordozza (pUC18 3xFlag dBigH1 dsRed) (62).

\subsubsection{PCR reakciók}

A PCR reakciókat a nullmutánshoz hasonlóan Q5 polimerázzal végeztem, a 2. táblázatban leírt programok szerint. A reakció templátja az $\$ 287 / 288$ pozíció mutagenezise során a pUC18 3xFlag dBigH1 dsRed plazmid volt, az S299 esetén az \$287/288 mutációt hordozó plazmid, az S331 mutagenezisekor pedig az a konstrukció, ami a másik három pozíciót már módosított formában hordozta. A PCR termékeket a korábban leírt módon ellenőriztem és tisztítottam. 


\begin{tabular}{|c|c|c|c|c|c|c|}
\hline \multicolumn{2}{|c|}{ S287/S288 } & \multicolumn{2}{|c|}{ S299 } & \multicolumn{2}{|c|}{ S331 } & \\
\hline S287/288A F & PSLIC F & S299A F & PSLIC F & S331A F & PSLIC F & \\
\hline PSLIC R & S287/288A R & PSLIC R & S299A R & PSLIC R & S331A R & \\
\hline (2613 bp) & (2947 bp) & (2578 bp) & (2982 bp) & (2482 bp) & (3078 bp) & \\
\hline $98^{\circ}$ & $30 \mathrm{mp}$ & $98^{\circ} \mathrm{C} 30 \mathrm{mp}$ & $98^{\circ} \mathrm{C} 30 \mathrm{mp}$ & $98^{\circ} \mathrm{C} 30 \mathrm{mp}$ & $98^{\circ} \mathrm{C} 30 \mathrm{mp}$ & \\
\hline 98 & $10 \mathrm{mp}$ & $98^{\circ} \mathrm{C} 10 \mathrm{mp}$ & $98{ }^{\circ} \mathrm{C} 10 \mathrm{mp}$ & $98^{\circ} \mathrm{C} 10 \mathrm{mp}$ & $\left.98^{\circ} \mathrm{C} 10 \mathrm{mp}\right]$ & \\
\hline 64 & $30 \mathrm{mp}$ & $66^{\circ} \mathrm{C} 30 \mathrm{mp}$ & $63^{\circ} \mathrm{C} 30 \mathrm{mp}$ & $67^{\circ} \mathrm{C} 30 \mathrm{mp}$ & $65^{\circ} \mathrm{C} 30 \mathrm{mp}$ & 6 ciklus \\
\hline 72 & 2 perc & $72{ }^{\circ} \mathrm{C} 2$ perc & $72{ }^{\circ} \mathrm{C} 2$ perc & $72^{\circ} \mathrm{C} 2$ perc & $72^{\circ} \mathrm{C} 2$ perc & \\
\hline 98 & $10 \mathrm{mp}$ & $98^{\circ} \mathrm{C} 10 \mathrm{mp}$ & $98^{\circ} \mathrm{C} 10 \mathrm{mp}$ & $98^{\circ} \mathrm{C} 10 \mathrm{mp}$ & $\left.98^{\circ} \mathrm{C} 10 \mathrm{mp}\right]$ & \\
\hline 72 & $30 \mathrm{mp}$ & $72{ }^{\circ} \mathrm{C} 30 \mathrm{mp}$ & $69^{\circ} \mathrm{C} 30 \mathrm{mp}$ & $72{ }^{\circ} \mathrm{C} 30 \mathrm{mp}$ & $72{ }^{\circ} \mathrm{C} 30 \mathrm{mp}$ & 30 ciklus \\
\hline 72 & 2 perc & $72{ }^{\circ} \mathrm{C} 2$ perc & $72{ }^{\circ} \mathrm{C} 2$ perc & $72^{\circ} \mathrm{C} 2$ perc & $72{ }^{\circ} \mathrm{C} 3$ perc & \\
\hline 72 & 3 perc & $72{ }^{\circ} \mathrm{C} 3$ perc & $72{ }^{\circ} \mathrm{C} 3$ perc & $72^{\circ} \mathrm{C} 3$ perc & $72{ }^{\circ} \mathrm{C} 3$ perc & \\
\hline $4^{\circ} \mathrm{C}$ & & $4^{\circ} \mathrm{C}$ & $4^{\circ} \mathrm{C}$ & $4^{\circ} \mathrm{C}$ & $4^{\circ} \mathrm{C}$ & \\
\hline
\end{tabular}

2. táblázat. PCR programok a $P O$ mutáns szekvenciát hordozó plazmid előállitásához szükséges DNS fragmentumok amplifikálásához.

\subsubsection{SLIC reakciók és plazmidok elökészítése}

Az egyes reakciók esetén a PCR-rel a 2. táblázatban leírt módon eloállított, majd tisztított DNS molekulákat hozzávetölegesen 1:1 moláris arányban mértem össze, majd a mintákat a fentebb részletezett módon kezeltem, transzformáltam, szélesztettem és preparáltam.

\subsubsection{Plazmidok ellenőrzése}

Az S287 és S288 pozíciók mutációja Eagl, az S299 pozícióé pedig Munl restrikciós endonukleáz felismerőhelyet hozott létre, így tesztemésztéssel ellenőriztem a plazmidok szerkezetét. Az S331 mutációjakor nem jött létre új hasitóhely, ezért kolónia PCR-rel ellenőriztem az S331A_C_F és S/A_C_R primereket használva. Ehhez egyedi baktérium telepeket mostam bele fogvájóval az elöre összemért PCR reakcióba (HOT FIREPol DNS polimeráz (Solis BioDyne), a gyártó utasításait követve), melynek paraméterei a következök voltak: $95{ }^{\circ} \mathrm{C} 15$ perc, $95{ }^{\circ} \mathrm{C} 30 \mathrm{mp}$, $60{ }^{\circ} \mathrm{C} 30 \mathrm{mp}, 72{ }^{\circ} \mathrm{C} 30 \mathrm{mp}, 72{ }^{\circ} \mathrm{C} 3$ perc, $4{ }^{\circ} \mathrm{C}$. A tesztek alapján megfelelönek bizonyult plazmidokat Sanger szekvenálással is ellenőriztem. Minden módosítás sikeres volt, így létrehoztam egy olyan plazmidot, amelyben a BigH1 minden eddig ismert foszforilációs helye hiányzik. 


\subsubsection{Beépítés pTZ vektorba és előkészítés injektálásra}

A nullmutáns elkészítésével azonos módon történt, melynek sémáját a 7. ábra mutatja be.

\subsection{FELHASZNÁLT DROSOPHILA VONALAK}

A kísérletekben felhasznált BigH1 mutáns törzseket csoportunk állította elő (62). Minden vonal a BigH1 fehérjét módosított formában hordozza, melyek közül a 3F (3x FLAG-jelölt BigH1-et kifejező) vonal a kísérletek során a fehérje expressziójának kimutatására és követésére, illetve kontrollként szolgált. A további vonalak BigH1-H1 kiméra fehérjéket hordoznak $(H B B, B H B, B B H, H B H, H H H)$, ahol mindhárom betű egy-egy domént jelez (első betü: N-terminális, második: globuláris, harmadik: C-terminális domén). Az N-terminális domén mutánsokat röviden $\mathrm{H} 1$ NTD-nek, a globuláris domén mutánsokat H1-GD-nek, a C-terminális domén mutánsokat H1-CTD-nek nevezzük. A domén határok a két fehérje esetén a következők: BigH1 N-terminális domén: M1-K97; BigH1 globuláris domén: P98T168; BigH1 C-terminális domén: D169-STOP354; H1 N-terminális domén: M1P44; H1 globuláris domén: S45-A119; H1 C-terminális domén: S120-STOP257. A HHH állatokban a teljes BigH1 kódoló szekvenciát His1 $(\mathrm{H} 1)$ kódoló szekvenciára cseréltük. Létrehoztunk továbbá egy olyan Drosophila vonalat, amely korai STOP kodont hordoz a BigH1 génben (NSTOP). A vad típusú kontrollként használt $w^{1118}$ törzset (BDSC_3605) és a H2Av-GFP transzgént kifejező Drosophila vonalat (BDSC_24163) Bloomingtonból szereztük be. A BigH1 gén genomi környezetét, a génmódosított állatok létrehozásakor felhasznált genomi szekvenciákat és a BigH1 mutáns Drosophila vonalak genotípusát a 8 . ábra mutatja be. 
A

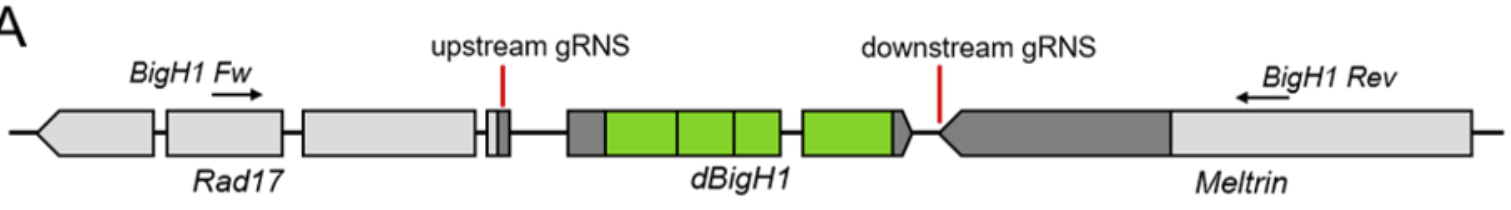

B

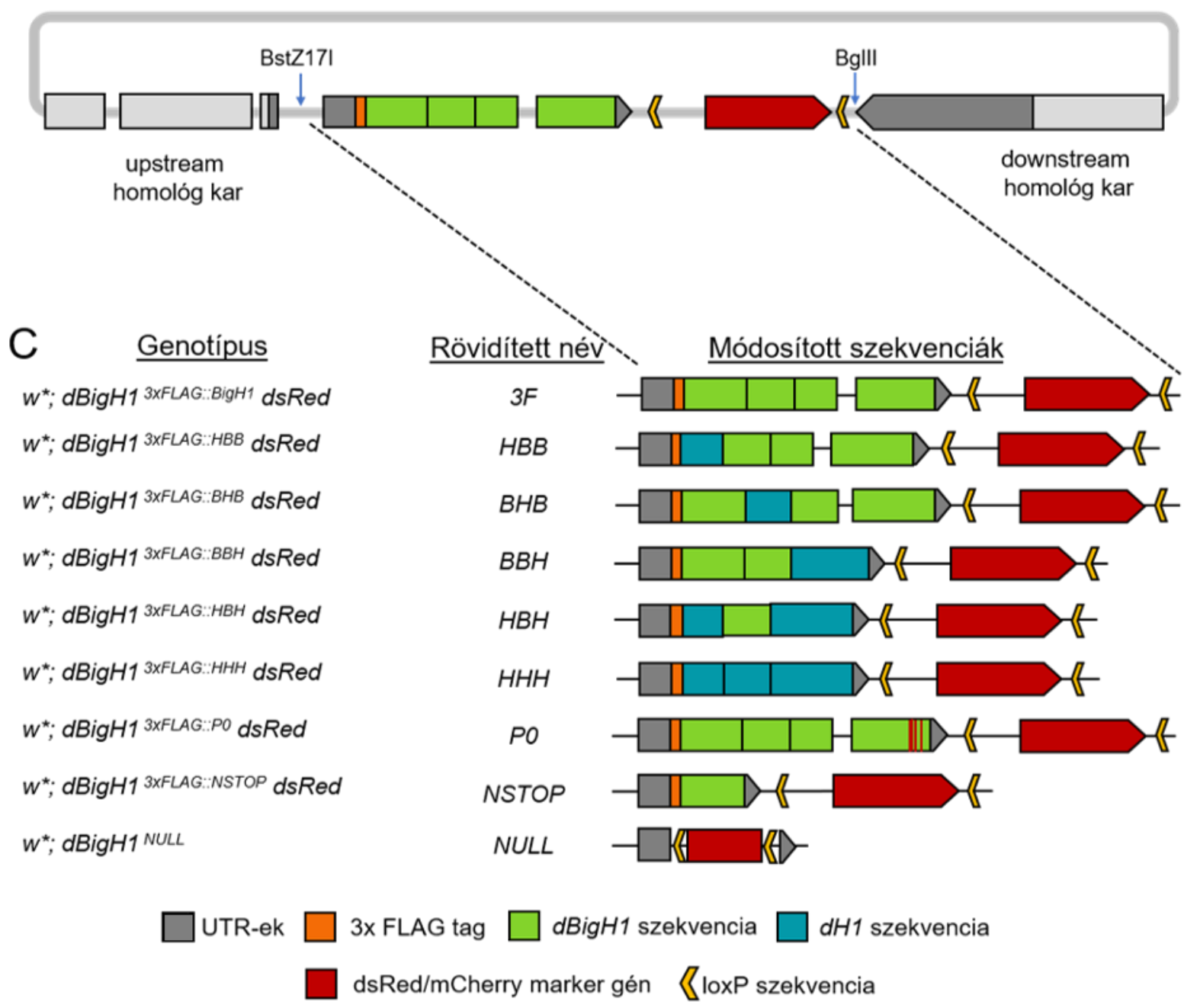

8. ábra. Módosított BigH1 szekvenciát hordozó Drosophila vonalak bemutatása. A) A BigH1 gén és genomi környezetének sematikus ábrázolása, a CRISPR/Cas9 alapú genomszerkesztésnél alkalmazott gRNS pár pozíciójának megjelölésével, illetve a szakasz amplifikálásához szükséges primer párokkal. B) A $3 F$ allélt hordozó vonal előállitásához felhasznált plazmid sematikus ábrázolása. A plazmid hordozza az upstream és downstream homológ karokat, a dsRed marker gént loxP helyek között, és a módosított BigH1 szekvenciát, melynek plazmidba klónozása BstZ17I és Bglll restrikciós enzimek segítségével történt. C) A módosított BigH1 gént hordozó állatok genotípusa, azok rövidített neve és a módosított szekvenciák felépítése. 


\subsection{DROSOPHILA EMBRIÓK GYÜJTÉSE ÉS ELŐKÉSZÍTÉSE}

$A z$ embriók gyűjtéséhez speciális táptalajra petéztettem az állatokat, melynek összetétele $10 \mathrm{~g}$ Bacto agar, $1 \mathrm{~g}$ cukor, $1 \mathrm{~g}$ szénpor, $2 \mathrm{ml}$ almaecet, $3 \mathrm{ml}$ 20\%-os nipagin $500 \mathrm{ml}$ tápoldathoz. Az embriókat ecset segítségével összegyűjtöttem, majd egy percre háztartási hipóba helyeztem, így dekorionáltam. Ezt követően alaposan mostam vízzel, majd Eppendorf csőbe helyeztem őket, lemértem a súlyukat analitikai mérlegen, és folyékony nitrogénben lefagyasztottam. Az embriókat felhasználásig $-80{ }^{\circ} \mathrm{C}$-on tároltam.

\subsection{FEHÉRJÉK MENNYISÉGI VIZSGÁLATA}

\subsubsection{Fehérje preparátumok készítése Western blothoz}

A fehérje preparátum készítéséhez 10-50 mg mennyiségű 1-2, illetve 3-4 órás embriókat használtam fel. A mintákat a fehérje extraktum elkészítése során végig jégen tartottam. A preparátum készítés alapja a Pérez-Montero és mtsai által leírt protokoll volt (51), melyet a következőképpen módosítottam. A fagyasztott embriókat $\mathrm{A} / 1$ pufferben $(0,23 \mathrm{M}$ szacharóz, $15 \mathrm{mM}$ Tris- $\mathrm{HCl} \mathrm{pH}$ 7.5, $60 \mathrm{mM} \mathrm{KCl}$, $15 \mathrm{mM} \mathrm{NaCl}, 0.15 \mathrm{mM}$ spermin, $0.5 \mathrm{mM}$ spermidin, $0.2 \mathrm{mM}$ PMSF, $14 \mathrm{mM}$ merkaptoetanol, $0.25 \mathrm{mM} \mathrm{MgCl}_{2}$ ) homogenizáltam, majd centrifugálással ülepítettem a csapadékot $\left(3300 \mathrm{~g}, 15\right.$ perc, $\left.4{ }^{\circ} \mathrm{C}\right)$. A felülúszót tiszta Eppendorf csőbe helyeztem, ez a nem kromatinkötött fehérjefrakciónak felel meg. A csapadékot megmostam egyszer A/1 pufferrel, majd egyszer A/2 pufferrel (15 mM Tris- $\mathrm{HCl} \mathrm{pH}$ 7.5, $60 \mathrm{mM} \mathrm{KCl}, 15 \mathrm{mM} \mathrm{NaCl}, 0.15 \mathrm{mM}$ spermin, $0.5 \mathrm{mM}$ spermidin, $0.2 \mathrm{mM}$ PMSF, $14 \mathrm{mM}$ merkaptoetanol, $0.25 \mathrm{mM} \mathrm{MgCl}_{2}$ ). Mosás után a csapadékot felvettem A/2 pufferben, majd 2x SDS minta puffert adtam hozzá, és 10 percig forraltam. A sóelúciós minták esetén a két mosás után felvettem a csapadékot olyan A/2 pufferben, amit kiegészítettem a megfelelő mennyiségü $\mathrm{NaCl}$-dal. A mintákat 10 percig jégen tartottam, majd centrifugálással ülepítettem a csapadékot (3300 g, 15 perc, $\left.4^{\circ} \mathrm{C}\right)$. A felülúszót áttettem egy tiszta Eppendorf csőbe, ez a sóeluált frakció. A csapadékot felvettem A/2 pufferben, ez a sóelúció után a kromatinkötött fehérjefrakció. Minden mintához 2x SDS minta puffert adtam, és forraltam 10 percig, majd $-20{ }^{\circ} \mathrm{C}$-on tároltam felhasználásig. Három független biológiai ismétlést végeztem. 


\subsubsection{Tricin-SDS-PAGE és Western blot}

A fehérjemintákat $10 \%$-os tricin-akrilamid gélen futtattam meg, amelyhez gélpuffert ( $1 \mathrm{M}$ Tris, $0,1 \% \mathrm{SDS}, \mathrm{pH} 8.45)$, anód puffert $(0,1 \mathrm{M}$ Tris- $\mathrm{HCl} \mathrm{pH}$ 8.9) és katód puffert (0,1 M Tris, 0,1 M tricin, 0,1\% SDS, pH 8.25) használtam fel (63). A gélt 30-50 V feszültséggel, $40 \mathrm{~mA}$ állandó áramerősséggel futtattam, amíg a fehérjék elérték a szeparáló gélt, majd másfél órán át folytattam a futtatást 150-170 V-on 120 mA mellett. Futás után a gélből a fehérje mintákat $0.2 \mu \mathrm{m}$ pórusméretú, metanollal aktivált PVDF membránra (Millipore) blottoltam (150 perc, $40 \mathrm{~V}, 300 \mathrm{~mA}$ ) transzfer pufferben (25 mM Tris, $192 \mathrm{mM}$ glicin, 0,1\% SDS, 20\% metanol). Blottolást követően a membránt desztillált vízzel mostam és Ponceau festékkel kezeltem, hogy meggyőződjek arról, hogy a transzfer egyenletes és buborékmentes volt. A festéket TBST-vel (10 mM Tris pH 8, $150 \mathrm{mM} \mathrm{NaCl}, 0.05 \%$ Tween 20) kimostam a membránból, amit ezután 5\%-os, TBST-ben oldott sovány tejporban blokkoltam 16 órát $4{ }^{\circ} \mathrm{C}$-on. Másnap a blokkoló folyadékot eltávolítottam, a membránt TBST-vel mostam, majd megfelelő hígítású elsődleges ellenanyaggal inkubáltam (anti-FLAG esetén 30 percig, anti-H3 esetén 2 óráig). Ezt követően a membránt 4x 10 percig mostam TBST-vel, majd megfelelő hígítású HRP-vel konjugált másodlagos ellenanyaggal kezeltem 1 órán át. Ezt újabb 4x 10 perc mosás követte, majd a membránt TBS oldatba (10 mM Tris $\mathrm{pH} 8,150 \mathrm{mM} \mathrm{NaCl}$ ) helyeztem 1 percre. Az előhívást megelőzően a membránt 10x hígított ECL reagensbe helyeztem, majd LICOR C-DiGit Chemiluminescence Western Blot Scanner segítségével felvételt készítettem róla. A felhasznált elsődleges és másodlagos ellenanyagok alkalmazása és forrása megtalálható az 2. Függelék táblázatban. A fehérjék mennyiségét ImageJ programmal (64) határoztam meg, a H3 fehérje mennyiségét használva bemérési kontrollnak, melynek segítségével az egyes mintákban található fehérje mennyiség összevethető. Az eredmények statisztikai értékeléséhez t-próbát használtam (two-tailed, unpaired).

\subsection{MNÁZ-ESSZÉ KORAI EMBRIÓ KROMATIN EXTRAKTON}

120-250 mg 0,5-2,5 órás embriót használtam fel a kísérletekhez. Hasonló módon a Western blotra készült mintákhoz, az embriókat homogenizáltam A/1 pufferben és centrifugálással ülepítettem a csapadékot $\left(3300 \mathrm{~g}, 15\right.$ perc, $\left.4^{\circ} \mathrm{C}\right)$. Az 
ülepített fázist mostam egyszer $\mathrm{A} / 1$ pufferrel $(0,23 \mathrm{M}$ szacharóz, $15 \mathrm{mM}$ Tris-HCl pH 7.5, $60 \mathrm{mM} \mathrm{KCl}, 15 \mathrm{mM} \mathrm{NaCl}, 0.15 \mathrm{mM}$ spermin, $0.5 \mathrm{mM}$ spermidin, $0.2 \mathrm{mM}$ PMSF, $14 \mathrm{mM}$ merkaptoetanol, $0.25 \mathrm{mM} \mathrm{MgCl}$ ), és egyszer $\mathrm{CaCl}_{2}$-dal kiegészített $\mathrm{A} / 2$ pufferrel ( $15 \mathrm{mM}$ Tris-HCl pH 7.5, $60 \mathrm{mM} \mathrm{KCl}, 15 \mathrm{mM} \mathrm{NaCl}, 0.15 \mathrm{mM}$ spermin, 0.5 $\mathrm{mM}$ spermidin, $0.2 \mathrm{mM}$ PMSF, $14 \mathrm{mM}$ merkaptoetanol, $0.25 \mathrm{mM} \mathrm{MgCl}, 1 \mathrm{mM}$ $\mathrm{CaCl}_{2}$ ), majd felszuszpendáltam szintén $\mathrm{CaCl}_{2}$-dal kiegészített $\mathrm{A} / 2$ pufferben. Az így kapott kromatin preparátum koncentrációját Nanodrop 2000 müszerrel mértem meg, majd a kromatint $60 \mu \mathrm{g}$-onként szétosztottam Eppendorf csövekbe és kiegészítettem $90 \mu \mathrm{l}$-re B pufferrel $(10 \mathrm{mM}$ Tris- $\mathrm{HCl} \mathrm{pH} \mathrm{7.5,60} \mathrm{mM} \mathrm{KCl,} 15 \mathrm{mM}$ $\mathrm{NaCl}, 0.15 \mathrm{mM}$ spermin, $0.5 \mathrm{mM}$ spermidin, $1 \mathrm{mM} \mathrm{CaCl}$ 2). 0.5-0.5 U MNáz enzimet adtam a kromatin preparátumokhoz, majd 30 percig emésztettem őket $37^{\circ} \mathrm{C}$-on. Ezt követően a mintákhoz EDTÁ-t adtam (10 mM végkoncentráció), és 5 percig jégen tartottam. Ezután a mintákat kihígítottam kétszeres térfogatra, $50 \mu \mathrm{g} / \mathrm{ml}$ RNáz enzimet adtam hozzájuk, és $37^{\circ} \mathrm{C}$-on inkubáltam 20 percig. Inkubálás után a fehérjéket denaturáltam $1 \%$ SDS és $1 \mathrm{M} \mathrm{NaCl}$ hozzáadásával, majd a DNS-t fenol:kloroform:izoamilalkohol extrakcióval kitisztítottam, és megfuttattam Bioanalyzer 2100 DNA 1000 chipen (Agilent). A mono- és multinukleoszómális DNS méretét és koncentrációját az egyes mintákban a 2100 Bioanalyzer Expert (Agilent) programot használva manuális integráció segítségével állapítottam meg. $A z$ eredmények statisztikai értékeléséhez t-próbát használtam (two-tailed, unpaired). Három független biológiai és két technikai ismétlést végeztem el.

\subsection{NUKLEOSZÓMA STABILITÁS VIZSGÁLAT KORAI EMBRIÓKBÓL PREPARÁLT MAGOKON (QINESIn ESSZÉ)}

100-200 mg 0,5-2,5 órás H2Av-GFP;+ és H2Av-GFP;HHH homozigóta embriót I/A pufferben (300 mM szacharóz, 10 mM HEPES pH 7.9, $10 \mathrm{mM} \mathrm{KCl,} 1.5$ $\mathrm{mM} \mathrm{MgCl2}, 0.1 \mathrm{mM}$ EGTA, $0.5 \mathrm{mM}$ DTT, $0.5 \mathrm{mM}$ PMSF, 1× proteáz inhibitor keverék) homogenizáltam és centrifugálással ülepítettem a sejtörmeléket (550 g, 1 perc, $4{ }^{\circ} \mathrm{C}$ ). A felülúszót tiszta Eppendorf csőbe pipettáztam és centrifugálással kiülepítettem a sejtmagokat (1300 g, 10 perc, $4{ }^{\circ} \mathrm{C}$ ). Az ilyen módon elválasztott magokat felszuszpendáltam I/A pufferben. Egy tiszta Eppendorf csőbe kimértem a minta térfogatának megfelelö mennyiségủ I/B. puffert (1.7 M szacharóz, $10 \mathrm{mM}$ 
HEPES pH 7.9, $10 \mathrm{mM} \mathrm{KCl}, 1.5 \mathrm{mM} \mathrm{MgCl} 2,0.1 \mathrm{mM}$ EGTA, $0.5 \mathrm{mM}$ DTT, $0.5 \mathrm{mM}$ PMSF, 1× proteáz inhibitor keverék), majd a mintákat pipettával rárétegeztem, és óvatosan összekevertem a két fázis közötti határréteget a pipetta tippel. A csapadékot centrifugálással elválasztottam (28000 g, 15 perc, $4{ }^{\circ} \mathrm{C}$ ), majd felszuszpendáltam II. pufferben (10 mM HEPES pH 7.9, $10 \mathrm{mM} \mathrm{KCl,} 2 \mathrm{mM} \mathrm{MgCl}$, $0.5 \mathrm{mM}$ DTT, $0.5 \mathrm{mM}$ PMSF, 1× proteáz inhibitor keverék). Az így kapott sejtmag szuszpenziót az Imre László és mtsai (65) által leírt protokoll szerint ágyaztam be 8 lyukú lemezekbe (ibidi). A magokhoz 1:3 arányban 1x PBS-ben (137 mM NaCl, 2,7 $\mathrm{mM} \mathrm{KCl}, 10 \mathrm{mM} \mathrm{Na} 2 \mathrm{HPO}_{4}, 1,8 \mathrm{mM} \mathrm{KH}_{2} \mathrm{PO}_{4}$ ) oldott alacsony olvadáspontú (LMP) agarózt (1\%) adtam. $22 \mu \mathrm{l}$ mintát a lyuk aljára csepegtettem, majd lefedtem az általam készített müanyag fedőlapokkal. Száradásig (5-20 perc, a gél rétegvastagságától függően) $37^{\circ} \mathrm{C}$-os légtermosztátba helyeztem a lemezt, majd 2 percig jégen tartottam. Minden lyukba $4{ }^{\circ} \mathrm{C}$-os $1 x$ PBS-t pipettáztam, hogy eltávolíthassam a fedölapokat. A mintákat $3 \times 3$ percig $4{ }^{\circ} \mathrm{C}$-os $1 \times$ PBS-sel mostam, majd a magokat $2 \times 10$ percig permeabilizáltam $4{ }^{\circ} \mathrm{C}$-os $1 \times \mathrm{PBS} / 5 \mathrm{mM}$ EDTÁ-ban oldott 1\% Triton X-100-zal. A mintákat újra mostam 3x 3 percig, majd 6x 10 percig $4{ }^{\circ} \mathrm{C}$-os $\mathrm{NaCl}$ oldattal kezeltem, különböző koncentrációkban (200, 400, 600, 800, 1000, 1200 és $1400 \mathrm{mM}$ ). A NaCl kezelést követően a magokat újra mostam, majd éjszakán át fixáltam 1x PBS/5 mM EDTÁ-ban oldott 1\%-os formaldehid oldattal, 4 ${ }^{\circ} \mathrm{C}$-on. A fixálást újabb három mosás követte, majd a magi DNS-t $12.5 \mu \mathrm{g} / \mathrm{ml}$ propídium-jodiddal festettem (szintén 1xPBS/5 mM EDTÁ-ban oldva). 30 perc inkubációt követöen a festéket lemostam $4{ }^{\circ} \mathrm{C}-\mathrm{os}, 1 \times$ PBS/5mM EDTA oldattal, majd a magokat Spinning Disk konfokális mikroszkóppal fényképeztük le (Visitron spinning disk konfokális mikroszkóp Yokogawa CSU-W1 egységgel és Andor Zyla 4.2 PLUS sCMOS kamerával, 40x objektív, NA:0,6) (9. ábra). A képek elemzése iCys 7.0 szoftverrel történt, az adatok normalizálása és értékelése pedig az Imre és mtsai (65) által közölt munka alapján. Négy független biológiai ismétlést végeztem el. 


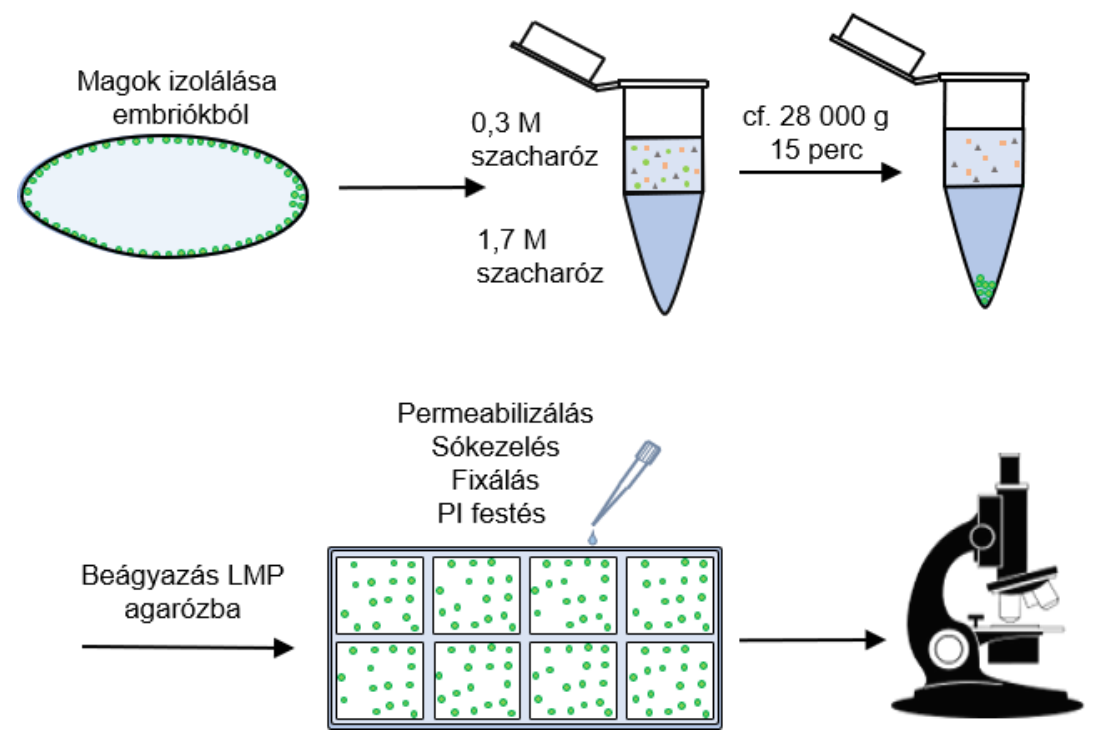

9. ábra A QINESIn nukleoszóma stabilitás assay munkafolyamata röviden bemutatva. $A z$ embriókból szacharóz grádiensen, nagy sebességgel centrifugálva magokat izoláltam, melyeket alacsony olvadáshőjủ agarózba ágyazást követően permeabilizáltam, majd sókezelésnek vetettem alá. A mintákat formaldehiddel fixáltam, a DNS-t pedig propídium-jodid (PI) festékkel jelöltem meg. A GFP jel kromatinról való távozását (amely a H2Av hiszton kromatinról távozására utal), Spinning Disk konfokális mikroszkóp segítségével készített képeken rögzítettük.

\subsection{GÉNEXPRESSZIÓ MÉRÉSE qPCR-REL}

\subsubsection{Transzpozonok kiválasztása}

Czech és mtsai (66) alapján a transzpozonok besorolhatók ivari, szomatikus és intermedier csoportokba, attól függően, hogy ivarvonalban, testi sejtekben vagy mindkét sejttípusban expresszálódnak. Ennek megfelelően mindegyik csoportból kiválasztottam néhányat, amelynek az expresszióját megmértem.

\subsubsection{RNS izolálás és DNáz kezelés}

A kísérlethez RNázoktól mentes MilliQ ultrapure (UP) vizet készítettem elö, melyet 1000x hígításban hozzáadott dietil-pirokarbonáttal (DEPC, Sigma) kezeltem, majd sterilizáltam (UPDEPC). 10 mg 0,5-1 órás vad típusú és HHH mutáns embriókból Trizolos extrakcióval készítettem RNS preparátumot. Az embriókat homogenizáltam $150 \mu \mathrm{l}$ TRIzol reagensben (Ambion), és kiegészítettem $40 \mu \mathrm{l}$ UPDEPC-vel, majd 5 percig inkubáltam $25^{\circ} \mathrm{C}$-on. Ezt követően a mintákhoz $40 \mu \mathrm{l}$ kloroformot adtam, és 
erősen vortexeltem 1 percig, majd újabb 5 percig inkubáltam $25^{\circ} \mathrm{C}$-on. Az RNS-t tartalmazó fázist centrifugálással elválasztottam (12700 rpm, 15 perc, $4{ }^{\circ} \mathrm{C}$ ), és egy tiszta Eppendorf csőbe helyeztem (felülúszó). Ezután a felülúszóhoz 1 térfogatnak megfelelő, tehát $80 \mu \mathrm{l}$ mennyiségü izopropanolt adtam, röviden vortexeltem, és 10 percig inkubáltam $25^{\circ} \mathrm{C}$-on. Az RNS-t tartalmazó pelletet centrifugálással elválasztottam (12700 rpm, 10 perc, $4{ }^{\circ} \mathrm{C}$ ), eltávolítottam az izopropanolt, majd a csapadékot mostam $500 \mu \mathrm{l} 75 \%$-os etanollal (8000 rpm, 5 perc, $4^{\circ} \mathrm{C}$ ). A csapadékot elszívófülke alatt szárítottam 15 percig, majd visszaoldottam $50 \mu \mathrm{l}$ UPDEPC-ben.

Az RNS preparátumok koncentrációját Qubit 2.0 fluorométer és Qubit RNA HS Assay Kit segítségével mértem meg, a gyártó utasításainak megfelelően. $3 \mu \mathrm{g}$ RNS mintát $25 \mu$ l végtérfogatban $3 \mu \mathrm{g}$ DNáz enzimmel (Thermofisher Scientific) kezeltem, $37{ }^{\circ} \mathrm{C}$-on 30 percig, majd a reakcióelegyet 2,5 $\mu$ l 50 mM EDTA hozzáadását követően $65{ }^{\circ} \mathrm{C}$-on inkubáltam 10 percig. A kezelés után az RNS koncentrációt újra megmértem.

\subsubsection{Reverz transzkripció}

A génexpresszió mérésekhez a cDNS szintézist $1 \mu \mathrm{g}$ RNS templáton végeztem el. A cDNS-t Taqman Reverse Transciption Reagents kittel (Thermofisher Scientific) készítettem, random hexamereket használva primerként (egy reakcióban: $1 \mu \mathrm{g}$ RNS, $5 \mu \mathrm{l}$ 10x RT puffer, $11 \mu \mathrm{l} 25$ mM MgCl $2,10 \mu \mathrm{l} 10$ mM dNTP mix, 2,5 ul $50 \mu \mathrm{M}$ random hexamer, $1 \mu \mathrm{l} 20 \mathrm{U} / \mu \mathrm{l}$ RNáz inhibitor, 1,3 $\mu$ l MultiScribe RT enzim, $50 \mu$ végtérfogatra kiegészítve UPDEPC vízzel). A cDNS készítés sikerességét hagyományos végpont PCR-rel ellenőriztem, aktin, tubulin és rp49 háztartási génekre specifikus primerek (200 nM végkoncentráció) segítségével (1. Függelék táblázat), Maxima Probe qPCR 2x Master Mix no ROX (Thermofisher Scientific) reagenst használva (program beállítások: $95^{\circ} \mathrm{C} 5$ perc, $95^{\circ} \mathrm{C} 30 \mathrm{mp}, 60$ ${ }^{\circ} \mathrm{C} 30 \mathrm{mp}, 72{ }^{\circ} \mathrm{C} 30 \mathrm{mp}, 72{ }^{\circ} \mathrm{C} 3$ perc, $4{ }^{\circ} \mathrm{C}$-ra lehütve, legalább 25 ciklus). A PCR sikerességét a végtermékek gélelektroforézisével ellenőriztem $2 \%$-os agaróz gélen. 


\subsection{4. qPCR és értékelés}

Az expressziós méréseket PikoReal Real-Time PCR System (Thermofisher Scientific) és a beépített szoftver használatával végeztem el. A reakcióban $30 \mathrm{ng}$ templát cDNS-t, 200 nM forward és reverz primert és GoTaq 2x qPCR Master Mixet (Promega) használtam. A program beállításait a 3 . táblázat, a felhasznált primereket az 1. Függelék táblázat mutatja. Az eredményeket a $2^{-\triangle \Delta C(T)}$ módszerrel értékeltem (67). Minden esetben három független biológiai ismétlést végeztem el, melyek mérése két párhuzamos reakcióban történt. Az eredmények statisztikai értékeléséhez t-próbát használtam (two-tailed, unpaired).

\begin{tabular}{|c|}
\hline qPCR program beállítások \\
\hline $95^{\circ} \mathrm{C} 7$ perc \\
\hline $\left.95^{\circ} \mathrm{C} 15 \mathrm{mp}\right]$ \\
\hline $60^{\circ} \mathrm{C} 59 \mathrm{mp}$. \\
\hline Data Acquisition \\
\hline $60^{\circ} \mathrm{C} 30 \mathrm{mp}$ \\
\hline Melt curve $60-95^{\circ} \mathrm{C}$ \\
\hline Data Aquisition \\
\hline $20^{\circ} \mathrm{C} 10 \mathrm{mp}$ \\
\hline
\end{tabular}

3. táblázat. Az expressziós mérésekhez használt qPCR program beállításai.

\subsection{BIGH1 ÉS H1 FEHÉRJÉK SZEKVENCIÁJÁNAK ÖSSZEHASONLÍTÁSA}

A BigH1 és H1 globuláris domének modelljének elkészítése a leírt módon történt (62), Modeller program (68) segítségével, a gH5 linker hiszton-nukleoszóma komplex (4QLC) (69) szerkezetét alapul véve. A különböző Drosophila fajok BigH1 és $\mathrm{H} 1$ fehérjeszekvenciáit az Uniprot, Flybase vagy NCBI adatbázisokból szereztem be (ezek elérhetősége a 4. táblázatban található). A fehérjeszekvenciák illesztését UGENE program (70) segítségével végeztem, a T-coffee illesztést alkalmazva (rés nyitási büntetés: -50 , rés kiterjesztési büntetés: 0 ). A távolsági mátrixokat szintén UGENE programban készítettem a szekvenciák hasonlósága alapján, az illesztésben található deléciók és inszerciók figyelembevételével. A $D$. 
melanogaster BigH1 és $\mathrm{H} 1$ fehérjék aminosav-összetételének százalékos eloszlását a ProtParam online eszköz segítségével határoztam meg (71).

\begin{tabular}{|l|c|c|c|}
\hline Drosophila fajok & Rövidített név & $\begin{array}{c}\text { BigH1 fehérjeszekvencia } \\
\text { azonosító }\end{array}$ & $\begin{array}{c}\text { H1 fehérjeszekvencia } \\
\text { azonosító }\end{array}$ \\
\hline D. melanogaster & DROME & Q8MSC4 (Uniprot) & P02255 (Uniprot) \\
\hline D. simulans & DROSI & B4QZS5 (Uniprot) & GD13565-PA (Flybase) \\
\hline D. sechellia & DROSE & B4HEK0 (Uniprot) & B4ILZ7 (Uniprot) \\
\hline D. erecta & DROER & B3P3M6 (Uniprot) & Q76FF6 (Uniprot) \\
\hline D. yakuba & DROYA & B4PSQ4 (Uniprot) & Q76FF6 (Uniprot) \\
\hline D. ananassae & DROAN & B3LVA7 (Uniprot) & GF22244_PA (Flybase) \\
\hline $\begin{array}{l}\text { D. pseudoobscura } \\
\text { pseudoobscura }\end{array}$ & DROPS & B5DKZ4 (Uniprot) & GA30978-PA (Flybase) \\
\hline D. persimilis & DROPE & B4GTB8 (Uniprot) & XP_002029056.2 (NCBI) \\
\hline D. willistoni & DROWI & B4NIM8 (Uniprot) & XP_002075981.1 (NCBI) \\
\hline D. mojavensis & DROMO & B4K7G8 (Uniprot) & XP_015022046.1 (NCBI) \\
\hline D. virilis & DROVI & XP_032295378.1 (NCBI) & GJ22541-PA (Flybase) \\
\hline D. grimshawi & DROGR & B4JGS3 (Uniprot) & XP_001997942.1 (NCBI) \\
\hline
\end{tabular}

4. táblázat. A szekvencia összehasonlításhoz felhasznált BigH1 és $\mathrm{H} 1$ fehérjeszekvenciák azonosítói és elérhetősége.

\subsection{BIOINFORMATIKA ÉS STATISZTIKA}

A plazmidokat és primereket SnapGene 1.1.3 program (72) segítségével terveztem meg. A Western blotokról készült felvételeket ImageJ programmal dolgoztam fel. A kísérletek eredményeinek ábrázolásához és a statisztikai értékeléshez GraphPad Prism 6 programot (73) használtam. 


\section{EREDMÉNYEK}

\subsection{Kanonikus ( $\mathrm{H} 1)$ és alternatív (BigH1) linker hisztonok szerepének in vivo összehasonlítását lehetővé tevő rekombináns gének és azokat hordozó transzgenikus Drosophila vonalak létrehozása}

A BigH1 alternatív linker hiszton embrionális fejödésben betöltött szerepének vizsgálatához olyan Drosophila vonalakat hoztunk létre, melyekben a vad típusú alternatív linker hiszton fehérjét BigH1-H1 kiméra fehérjék helyettesítik. Annak biztosítására, hogy a kiméra fehérjék idő- és szövetspecifikus kifejeződése megfeleljen a BigH1 linker hiszton specifikus expressziós mintázatának, a rekombináns géneket tartalmazó Drosophila vonalakat CRISPR/Cas9 módszert alkalmazva, in situ génszerkesztéssel hoztuk létre. A BigH1 domének (B) szerepének vizsgálatára négy allélban a két fehérje doménjeit kódoló DNS szekvenciákat felcseréltük $(H B B, B H B, B B H, H B H)$, egy továbbiban pedig a BigH1 kódoló régióját teljes mértékben a $H 1$ kódoló régiójára cseréltük $(H H H)$. Minden kimérát 3x FLAG epitóp jelöléssel láttunk el, lehetővé téve a módosított BigH1 lókuszról származó fehérjék nyomon követését in vivo és in vitro kísérletekben. A kiméra fehérjéket kódoló gének létrehozásakor csak a gén fehérjét kódoló szekvenciáját módosítottuk, a promóter és az UTR-ek érintetlenek maradtak. Létrehoztunk két funkcióvesztéses BigH1 allélt is. Ezek közül az egyikben a BigH1 gén korai STOP kodont hordoz (NSTOP), a másikban pedig a kódoló régiót mCherry markerre cseréltük (NULL). Ezekről a várakozás szerint nem termelődik BigH1 fehérje, illetve a BigH1 gén transzkripciós szabályozása szerint termelődő mCherry riporter gén jelzi, hogy mikor és hol kellene termelödnie. Annak érdekében, hogy megbizonyosodjunk arról, hogy a genetikai manipuláció, azaz a PAM (Protospacer Adjacent Motif, Cas9 helyspecifikus targetálásához szükséges NGG DNS motívum) szekvenciák elrontása, valamint a dsRed markergén beépítése a kicserélt genomi szakaszon nem befolyásolja a fehérje kifejeződését, 3x FLAG (3F) epitóp-taggel jelölt BigH1 fehérjét hordozó állatokat hoztunk létre. Elkészítettünk továbbá egy olyan BigH1 mutánst is, amelyben négy szerin aminosavat (287., 288., 299. és 331. aminosav pozíciók (61)), melyekről feltételezik, hogy foszforilációval módosulhatnak, alaninokra cseréltünk $(P 0)$. Valamennyi mutáns allél létrehozása az Anyagok és módszerekben leírtak szerint, a 8. ábrán vázolt lépéseket követve történt. 
Az én feladatom a NULL és $P O$ mutáns allélok klónozása volt, amelyekhez létrehoztam a módosított BigH1 szekvenciákat hordozó plazmidokat. Az ezeknek a plazmidoknak a létrehozásához használt primereket az 1. Függelék táblázat tartalmazza. A konstruktokat két lépésben készítettem el. Elsőként pUC18 plazmidban módosítottam a BigH1 gént. Ezután a módosított szekvenciát pTZ plazmidba építettem, amely tartalmazta a homológ karokat, és amelyben a PAM szekvencia el volt rontva, így a Cas9 már nem volt képes hasítani. Az elkészült plazmidokat restrikciós endonukleáz emésztéssel, valamint Sanger szekvenálással ellenőriztem, meggyőződve róla, hogy megfelelnek a tervezettnek és nem tartalmaznak nem kívánt nukleotid eltéréseket.

Ezt követően a plazmidokat a Szegedi Biológiai Kutatóközpont Drosophila Injektáló Szolgálata alkalmas Drosophila vonalak petéibe injektálta, majd csoportunkban azokból Drosophila vonalakat alapítottunk. A transzgenikus állatokból nyert genomi DNS Sanger-szekvenálásával ellenőriztük a BigH1 gén módosításának sikerességét (62). Megteremtettük a kísérleti rendszert, ami alkalmas az alternatív linker hiszton szerepének in vivo vizsgálatára.

\subsection{Normál laboratóriumi körülmények mellett $\left(25^{\circ} \mathrm{C}\right)$ a kanonikus linker hiszton képes az alternatív linker hiszton embrionális fejlödésben betöltött szerepének helyettesítésére}

A létrehozott rekombináns linker hiszton fehérjéket termelő Drosophila törzsek első jellemzésére megvizsgáltuk azok életképességét a normál laboratóriumi tenyésztési körülmények mellett (standard Drosophila táptalaj, $25^{\circ} \mathrm{C}$ ). Azt tapasztaltuk, hogy a mutánsok a vad típushoz és a kontroll allélhoz (3F) hasonló túlélést mutatnak (10. ábra). 


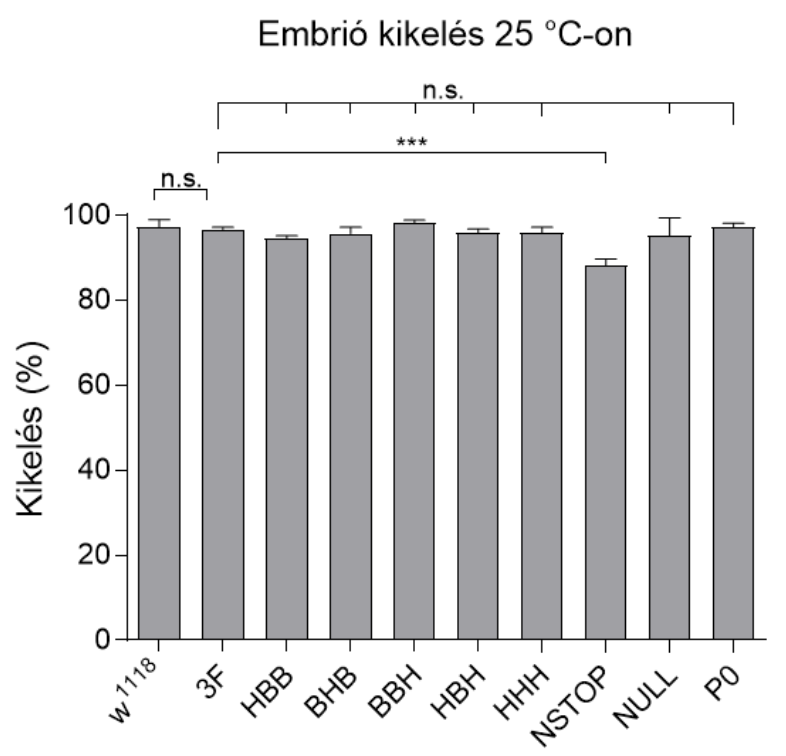

10. ábra. $25^{\circ} \mathrm{C}$-on a BigH1 fehérje nem esszenciális az embrionális fejlődéshez. Vad típusú $\left(w^{1118}\right)$ és génmódosítással létrehozott BigH1 mutáns embriók kikelési aránya $25^{\circ} \mathrm{C}$-on. Három párhuzamos kísérletet végeztünk, kísérletenként 77-399 db (átlagosan 239 db) 0-30 perces embrión, melyeket 36 órán át $25^{\circ} \mathrm{C}$-on tartottunk. A hibasávok reprezentálják a szórást (standard deviation). Statisztikai értékelés: t-próba (two-tailed, unpaired). p-értékek: n.s. $=$ nem szignifikáns, ${ }^{* * *} \leq 0.001$.

A következő kísérletsorozattal azt vizsgáltam, hogy képződik-e fehérje a mutáns BigH1 allélokról, és hogy a kontrollként használt 3x FLAG vad típusú BigH1hez $(3 F)$ képest kimutatható-e eltérés a kiméra fehérjék mennyiségében. Ehhez a taggel ellátott kontroll (3F), a BigH1-H1 kiméra $(H B B, B H B, B B H, H B H)$ és $H H H$ mutáns embriókból preparált fehérjemintákat Western blottot használva hasonlítottam össze. Mivel minden módosított fehérje 3x FLAG epitóp taget tartalmaz, az egyes kimérák kifejeződésének mértéke ugyanolyan ellenanyagot használva jól összehasonlítható. A vad típusú embriókon végzett Western blot alapján az anti-FLAG antitest specifikus kötődést mutat a FLAG taghez, mivel nem jelennek meg nem specifikusan reagáló sávok a vad típusú mintában. Az egyes kiméra fehérjék méretét a 3 . Függelék táblázatban foglaltam össze. Minden vizsgált, és várhatóan expresszálódó fehérje kifejeződik 1-2 és 3-4 órás embriókban is, azonban nem egyforma mértékben. A nullmutáns állatokban (NULL és NSTOP) nem fejeződik ki BigH1 fehérje (11A. ábra). Az egyes fehérjék expressziós szintjét a H3 belső kontroll alapján kiszámítva a $3 F$ kontrollhoz képest adtam meg (11B. ábra). A vizsgált mutáns fehérjéket a várakozásnak megfelelő mérettartományban mutattam ki. 
A
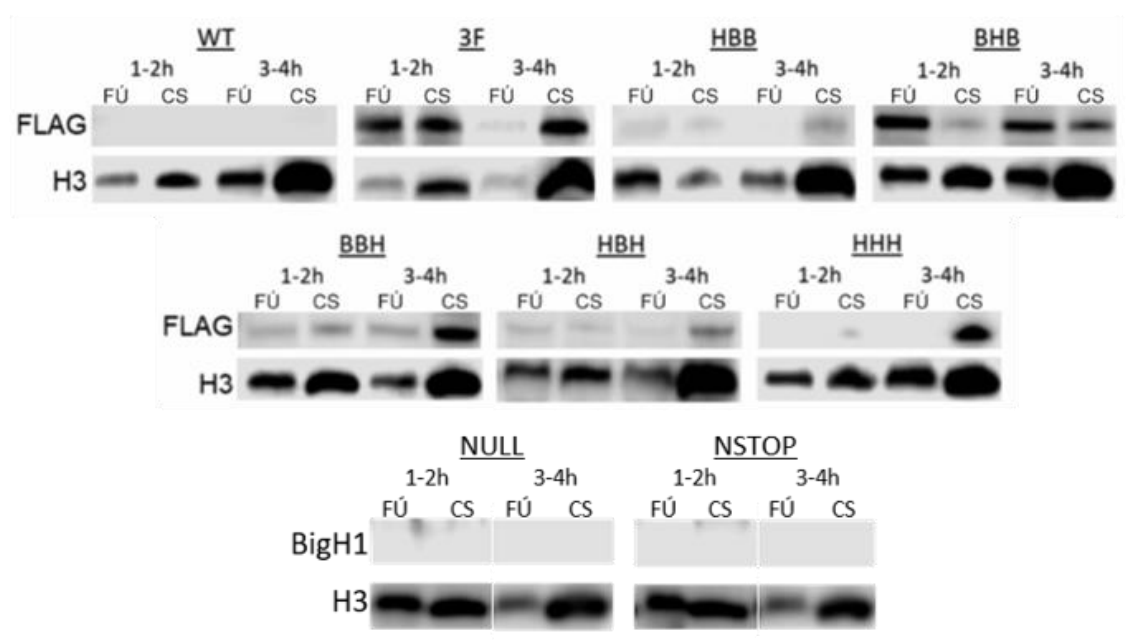

B

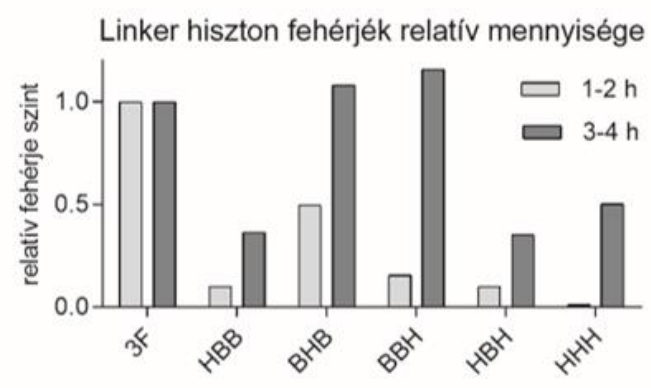

11. ábra. A H1-NTD típusú BigH1 mutáns fehérjék mennyisége alacsonyabb embrionális szövetben, mint a vad típusú és a többi mutáns fehérjéé. A) Génmódosítással létrehozott BigH1 mutáns allélokról termelődő fehérjék kimutatása Western blottal 1-2 és 3-4 órás embriókból származó nem kromatinkötött (FÚ, felülúszó) és kromatinkötött (CS, csapadék) fehérje preparátumból, anti-FLAG vagy anti-BigH1 ellenanyaggal. Belső kontrollként az anti-H3 ellenanyaggal kimutatott H3 core hiszton fehérjét használtam. B) Módosított BigH1 fehérjék mennyiségi összehasonlítása a Western blot kísérlet alapján, a 3F vad típusú, 3x FLAG taggel ellátott fehérje mennyiségéhez viszonyítva. Az egyes oszlopok az 1-2 vagy 3-4 órás mintákban mért összes módosított fehérjét reprezentálják (kromatinkötött és nem kromatinkötött együttesen). A fehérjeszintek meghatározása ImageJ program segítségével történt, a H3 fehérje mennyiségére normalizálva. Az ábra egy reprezentatív kísérletet mutat be.

A Western blottok értékelésével nyert eredmények azt bizonyították, hogy minden létrehozott és vizsgált mutáns esetében, amelyröl fehérje termelődhet ( $3 F$, $H B B, B H B, B B H, H B H, H H H)$, az a kromatinkötött frakcióban kimutatható. Immunhisztokémiai kísérletekkel igazoltuk ezeket a megfigyeléseket. $\mathrm{Az}$ immunfestések bizonyították továbbá azt is, hogy a BigH1 mutáns allélokról termelődő fehérjék a szincíciális blasztoderma sejtmagjaiban mutathatók ki, és a cellularizálódást követően mennyiségük csökken, a késői embrionális fejlődés 
során pedig már csak az ivarvonal sejtjeire korlátozódnak, tehát kifejeződési mintázatuk a vad típusú fehérjével megegyező. (12. ábra).

A bemutatott kísérletek alapján megállapítható, hogy a BigH1-H1 kimérák és a teljes hosszúságú szomatikus $\mathrm{H} 1$ fehérje a vad típusú BigH1 fehérjéhez hasonlóan sejtmagi lokalizációt mutatnak és jelenlétük kromatinhoz asszociált, így feltételezzük, hogy a BigH1 funkcionális helyettesítésére alkalmasak a korai embrionális fejlődés során. 
A
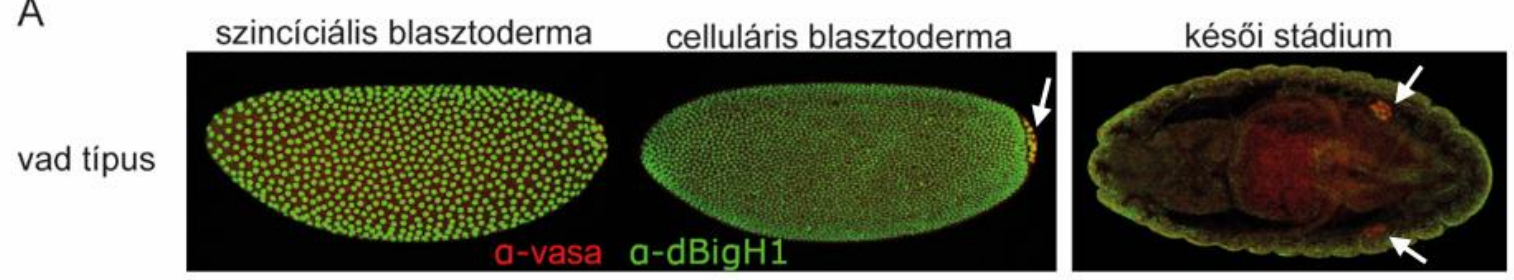

B

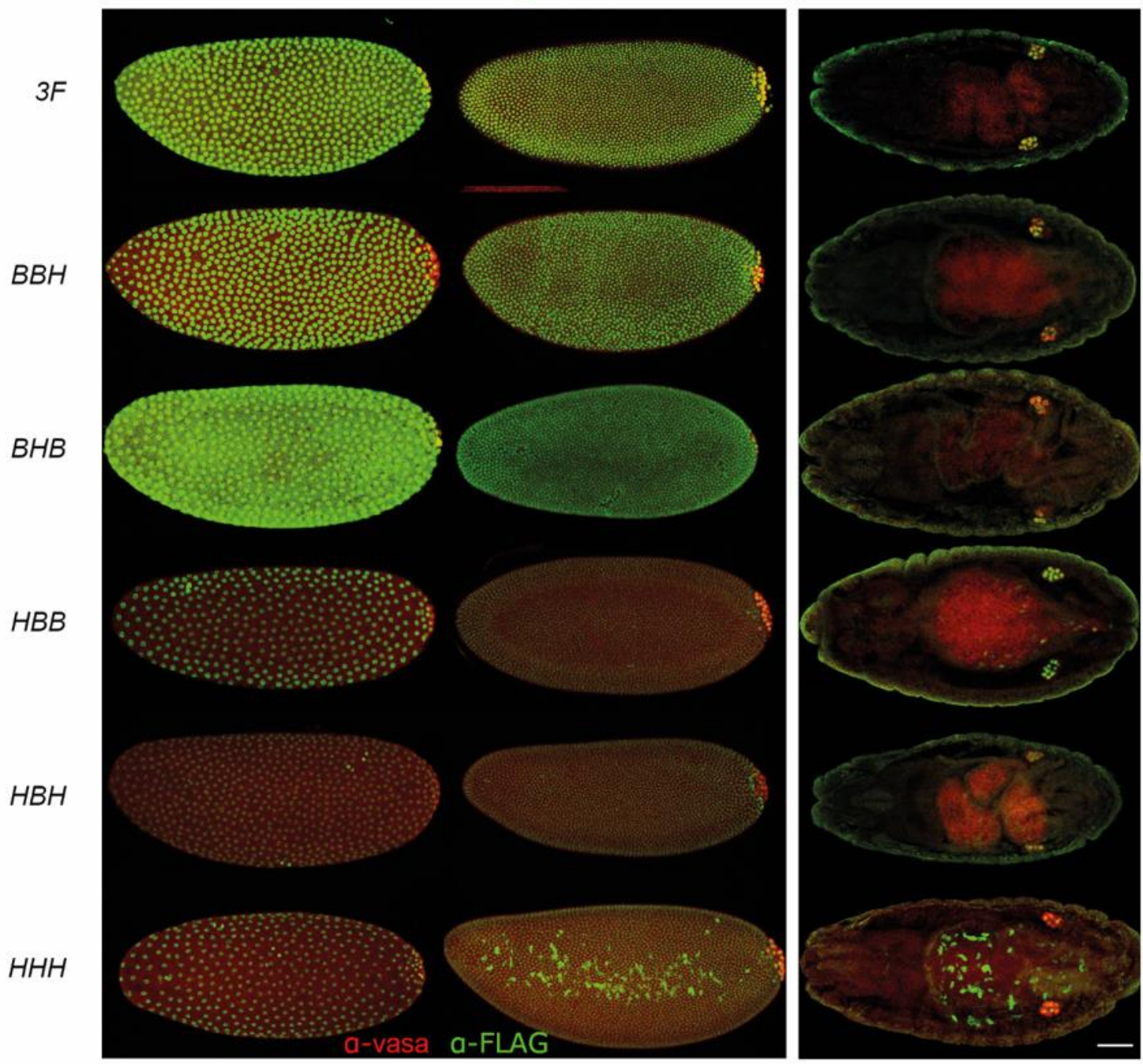

12. ábra BigH1 kiméra fehérjék kifejeződési mintázata embrióban a vad típussal megegyező.

A) Vad típusú (anti-dBigH1, zöld) és B) módosított BigH1 fehérjék (anti-FLAG, zöld) kimutatása immunfestéssel, szincíciális blasztoderma (első oszlop), celluláris blasztoderma (második oszlop) és késői stádiumú (harmadik oszlop) embriókban. A fehér nyíl jelöli a primordiális ivarsejteket, melyek kimutatása anti-vasa ellenanyaggal történt (piros). Az első két oszlop fotói azonos fényképezési és képszerkesztési beállításokkal készültek. A skála (jobb alsó sarok) 50 m-t jelent.

\subsection{A BigH1 $\mathrm{N}$-terminális doménje szerepet játszik a fehérje megfelelő expressziójában}

Western blot kísérletekkel a különböző BigH1/H1 kiméra génekröl termelődő fehérjék mennyiségében lényeges különbségeket mutattam ki, és ezt a 
megfigyelést immunhisztokémiai kísérletek eredményei is alátámasztották (11-12. ábrák). Azoknak a kiméra fehérjéknek a mennyisége, amelyeknél a BigH1 Nterminális doménje $\mathrm{H} 1$ típusúra van cserélve $(\mathrm{HBB}, \mathrm{HBH}, \mathrm{HHH}$, összefoglaló néven H1-NTD), kevesebb, mint fele a 3F-hez viszonyítva, melyet kontrollként használtam. Ez felveti a kérdést, hogy a különbséget mi okozza: csökkent mRNS expresszió, az mRNS rövid féléletideje, alacsony szintű transzláció vagy az mRNS-ről képződött fehérje gyors degradációja.

Annak kiderítésére, hogy az eltérő fehérjemennyiség esetleg eltérő mRNSszint következménye-e, összehasonlítottam az egyes mRNS-ek mennyiségét 0,5-1 órás preblasztoderma stádiumú embriókban. Mivel e tekintetben elsősorban a vad típusú alternatív linker hiszton és a kanonikus linker hiszton mennyiségi összevetése érdekes, az összehasonlítást a $H H H$ és $3 F$ kontroll vonalakban kimutatható mRNS-ek között végeztem el. Az elöbbi megfelel a BigH1 gén szabályozó régióival kifejezett kanonikus $H 1$ szekvenciának, az utóbbi a BigH1-nek. A kvantitativ RT-PCR módszerrel végzett összehasonlítás eredményeként azt tapasztaltam, hogy a $H H H$ mRNS mennyisége csak harmada a $3 F$ típusú mRNS mennyiségének (13. ábra). Tehát az alacsony $H H H$ fehérjemennyiség összhangban van a szintén csökkent $H H H$ mRNS mennyiséggel. A csökkent linker hiszton mennyiség ugyanakkor a $H H H$ gént hordozó állatokban nem befolyásolja az életképességet $25^{\circ} \mathrm{C}$-on. 


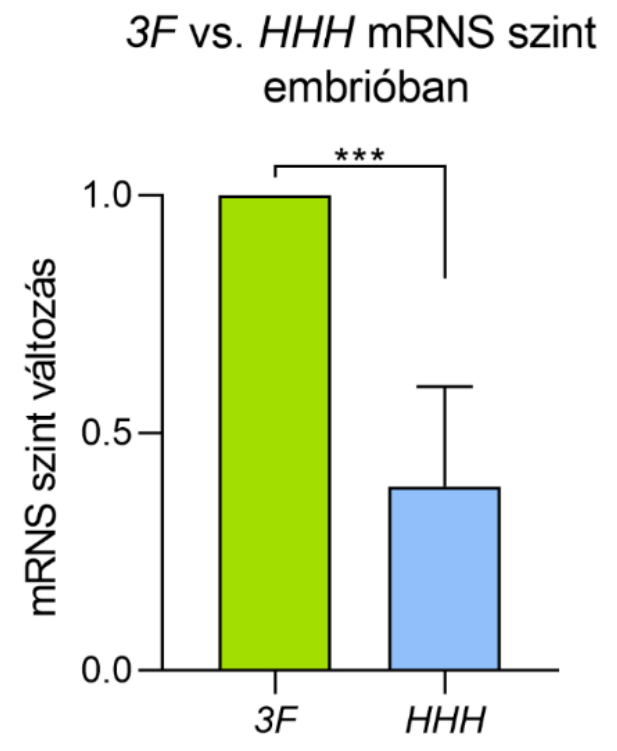

13. ábra. A HHH mutáns allélról kevesebb mRNS képződik, mint a $3 F$ vad típusú kontroll allélról. $3 F$ és $H H H$ korai embriókból preparált $3 F$ és $H H H$ mRNS mennyiségének összehasonlítása kvantitatív RT-PCR segítségével. A HHH embriókban mért $H H H$ mRNS szintet a $3 F$ embriókban mért $3 F$ mRNS szinthez viszonyítva adtam meg, kísérletenként páronkénti összehasonlítással, ahol a $3 F$ kontrollban mért értéket 1-nek vettem. Endogén kontrollként az aktin háztartási gén mRNSének mennyiségét használtam. A hibasáv a szórást reprezentálja (standard deviation). Statisztikai értékelés: t-próba (two-tailed, unpaired). p-érték: ${ }^{* * *} \leq 0.001$. Az ábra három független biológiai mintán végzett 2-2 technikai párhuzamos mérés eredményét mutatja be.

\subsection{A BigH1 globuláris és C-terminális doménjének cseréje kanonikus H1 típusúra emelkedett DNS-károsodással jár}

Western blot és immunhisztokémia kísérletek alapján a kimérák doménösszetétele befolyásolja az elérhető kiméra fehérje mennyiségét a korai embrióban. Ez arra utal, hogy bár normál körülmények között minden kiméra életképes, a BigH1 és $\mathrm{H} 1$ domének nem egyenértékủek. A következő kísérletsorozat célja annak feltérképezése volt, hogy a BigH1-nek mely doménjei nélkülözhetetlenek a funkciója ellátásához.

A korai szincíciális blasztoderma stádiumú embriókban nagyon gyors osztódások követik egymást, azonban a DNS hibajavitásért felelős útvonalak nem aktívak (74). Éppen ezért az osztódás során DNS hibákat felhalmozó sejtmagokat az embrió eliminálja. Ilyenkor az érintett magok besüllyednek a kortikális rétegböl az embrió belsejébe: ezt nevezzük mag eliminációnak (nuclear fallout) (75). A 
létrehozott BigH1 mutáns állatok vizsgálatával kimutattuk, hogy azokban az embriókban, amelyek olyan kiméra fehérjét termelnek, amelyben a BigH1 Cterminálisát vagy globuláris doménjét $\mathrm{H} 1$ típusúra cseréltük (összefoglaló nevükön H1-CTD és H1-GD kimérák), gyakoribb a magok eliminációja (erősebb nuclear fallout fenotípust mutatnak). Ez megfigyelhetö az NSTOP, NULL és PO mutánsokban is. Bár a $P 0$ allél esetén is szignifikáns különbség tapasztalható a $3 F$ kontrollhoz mérten, azonban nem olyan nagy mértékben, és a fenotípus inkább a vad típushoz hasonló (14A. ábra). A besüllyedő magok pozitívak voltak gammaH2Av festésre, ami a DNS-károsodás jellemzője (14B. ábra) (76). Ez arra utal, hogy a fenotípust a DNS sérülése okozza ezekben a kimérákban, azonban $25^{\circ} \mathrm{C}$-on olyan alacsony a fenotípus expresszivitása, hogy az nem befolyásolja az embriók életképességét. A HHH mutáns embriókban lesüllyedő magok emellett PCNA replikációs marker (77) festődést is mutatnak (14C. ábra), ami arra enged következtetni, hogy ezekben a magokban felborul az osztódási szinkronitás és a replikáció lemarad a nem lesüllyedő magokhoz képest, melyek PCNA festésre negatívak. Mindezek alapján feltételezzük, hogy a mag elimináció fenotípus hátterében a nem megfelelő replikáció áll. 

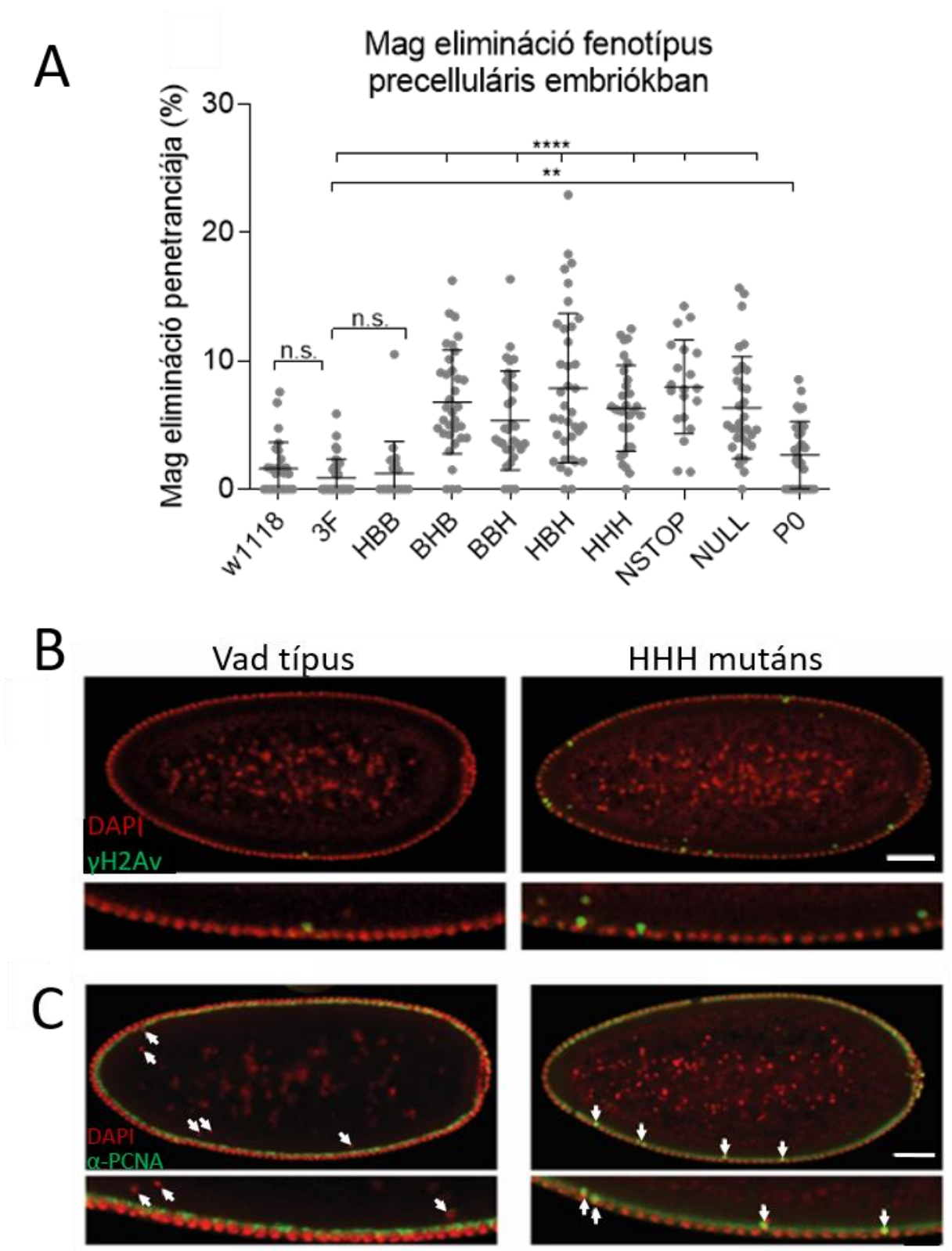

14. ábra. A H1-CTD és BigH1 nullmutáns embriók mag elimináció fenotípust mutatnak $\left(25^{\circ} \mathrm{C}\right)$.

A) A mag elimináció fenotípus penetranciája vad típusú ( $w^{1118}$ ) és módosított BigH1 allélt hordozó precelluláris embriókban. A kísérletben három párhuzamos mérés során 19-37 (átlagosan 30) db , 1-2 órás embriót vizsgáltunk. A hibasávok reprezentálják a szórást (standard deviation). Statisztikai értékelés: t-próba (two-tailed, unpaired). p-értékek: n.s. $=$ nem szignifikáns, ${ }^{* *} \leq 0.01,{ }^{* \star * *} \leq 0.0001$. B) Mag elimináció fenotípus bemutatása immunfestéssel egy-egy reprezentatív vad típusú és $H H H$ mutáns embrión. A DNS-t DAPI festés (piros), a DNS-károsodást mutató magokat anti- $ү \mathrm{H} 2 \mathrm{Av}$ (zöld) festés jelöli. C) PCNA (zöld) festés egy-egy reprezentatív, a sejtciklusnak azonos fázisában lévő vad típusú és $H H H$ mutáns embrión. Fehér nyilak jelölik a lesüllyedő magokat. A skála 50 m-t jelent. 


\subsection{A BigH1 globuláris és C-terminális doménje szükséges a fehérje megfelelő müködéséhez alacsony hőmérsékleten}

A BigH1 fehérje standard laboratóriumi körülmények között $\left(25^{\circ} \mathrm{C}\right)$ nem tünik létfontosságúnak, hiszen a kiméra fehérjét kifejező és a nullmutáns állatok is életképesek. Azonban mivel a magok eliminációját tapasztaltuk, felmerült a kérdés, hogy magasabb vagy alacsonyabb hőmérsékleten ez a jelenség kifejezettebb-e? Az embrionális túlélést ezért megvizsgáltuk $30{ }^{\circ} \mathrm{C}$ és $15{ }^{\circ} \mathrm{C}$ hömérsékleten is. Azt tapasztaltuk, hogy a magasabb hőmérséklet nem befolyásolta az embriók kikelését (15A. ábra), azonban alacsony hőmérsékleten elpusztul azoknak az embrióknak a jelentős része, amelyek $\mathrm{H} 1-\mathrm{CTD}$ vagy $\mathrm{H} 1-\mathrm{GD}$ típusúak $(B H B, B B H, H B H, H H H)$ (15B. ábra). Ezekben az embriókban immunfestéssel erős mitótikus hibákat (15C. ábra középső panel), valamint az osztódási szinkronitás felbomlását (15C. ábra alsó panel) detektáltunk, ami összhangban van a tapasztalt mag elimináció fenotípussal, amely DNS-károsodásra utalt. Mindebböl arra következtetünk, hogy a BigH1 globuláris és C-terminális doménjei szükségesek ahhoz, hogy a fehérje alacsony hőmérsékleten ellássa a feladatát. 


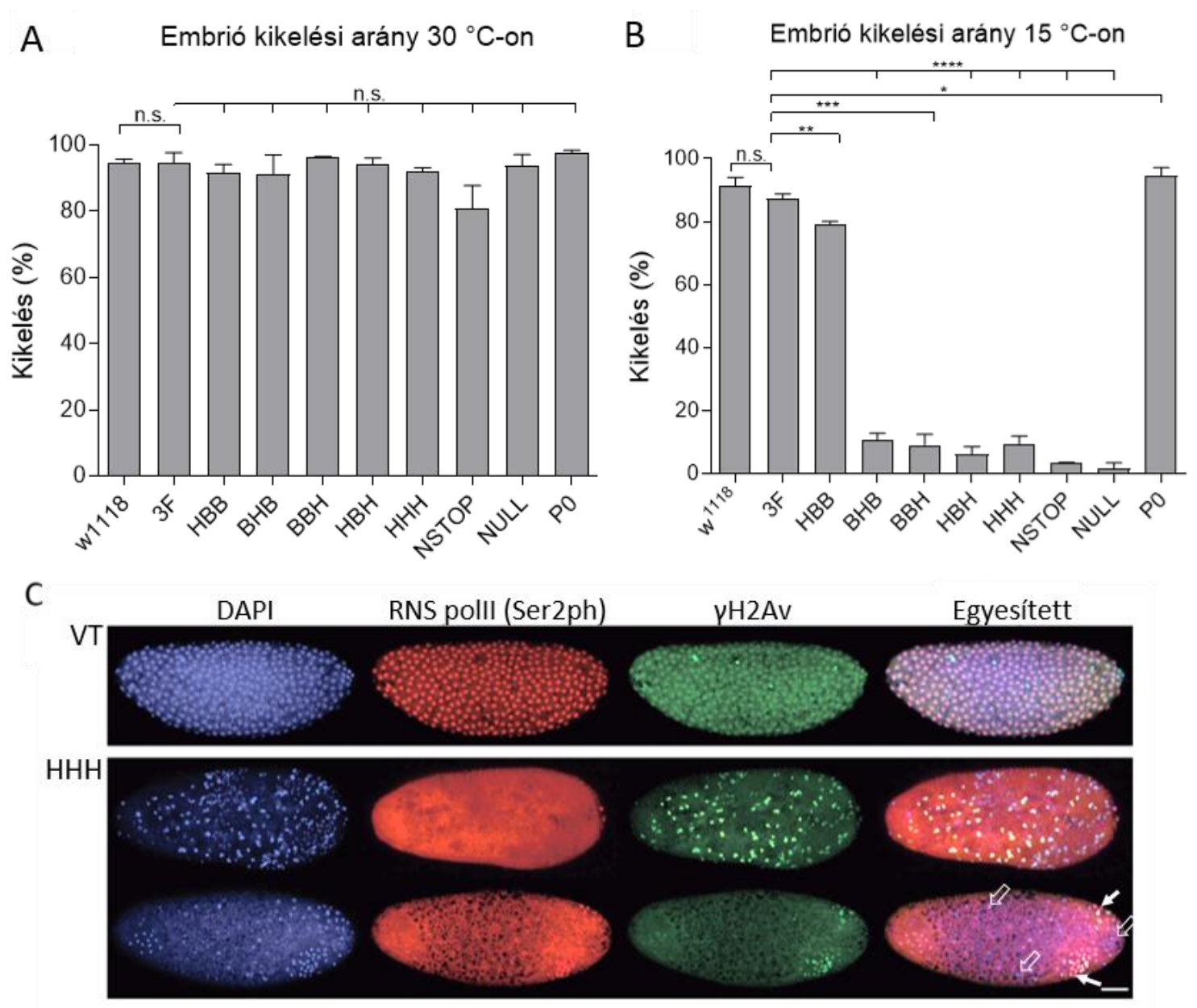

15. ábra. A H1-CTD és BigH1 nullmutáns embriók $15^{\circ} \mathrm{C}$-on csökkent életképességet és mitótikus hibákat mutatnak. Vad típusú $\left(w^{1118}\right)$ és génmódosítással létrehozott BigH1 mutáns embriók kikelési aránya A) $30{ }^{\circ} \mathrm{C}$-on (genotípusonként 49-315, átlagosan 154 db embrió) és B) 15 ${ }^{\circ} \mathrm{C}$-on (genotípusonként 51-436, átlagosan $180 \mathrm{db}$ embrió). Kísérletenként három párhuzamos mérés történt. A hibasávok a szórást mutatják (standard deviation). Statisztikai értékelés: t-próba (two-tailed, unpaired). p-értékek: n.s.=nem szignifikáns, ${ }^{*} \leq 0.05,{ }^{* *} \leq 0.01,{ }^{* * *} \leq 0.001,{ }^{* * * *} \leq 0.0001$. C) Mitótikus hibák a $H H H$ mutánsban, $15{ }^{\circ} \mathrm{C}$-on. Immunfestés vad típusú (VT) és $H H H$ mutáns szincíciális blasztoderma stádiumú embriókon, amelyeket $15^{\circ} \mathrm{C}$-on tartottunk a petézést követöen. A DNS-t DAPI-val, az RNS polimeráz II-t anti-RNS pollI Ser2ph, a kettős szálú DNS töréseket antiүH2Av ellenanyaggal festettük meg. A HHH mutáns embriókról készült felső ábrasor aggregálódott magokat tartalmazó embriót mutat be. Az alsó ábrasorban látható embrióban szigetszerüen található meg néhány mag, amik látszólag normálisan osztódnak. A fehér nyilak RNS pollI Ser2ph pozitív, az üres nyilak RNS polll Ser2ph negatív magokat jelölnek, ami az osztódási szinkron felbomlására utal. A skála $50 \mu \mathrm{m}$-t jelent. 


\subsection{A $H H H$ mutáns állatokban megváltozik a transzpozon RNS-ek expressziója}

A BigH1 nem csupán a korai embrióban, de a hím és nőstény ivarvonalban is kifejeződik, melyek olyan szövetek, ahol a transzpozonok elleni védekezés különösen kritikus. A Drosophila szomatikus $\mathrm{H} 1$ fehérjét korábban már összefüggésbe hozták a transzpozonokkal szembeni védekező rendszerrel $(33,78)$. Célunk annak vizsgálata volt, hogy a BigH1 a H1-hez hasonlóan hozzájárul-e ehhez a folyamathoz. Ennek vizsgálatára különböző transzpozon RNS-ek mennyiségét hasonlítottam össze vad típusú és HHH mutáns állatokban.

A korai embrió transzkripcionálisan inaktív, és a benne megtalálható RNS-ek túlnyomó része az anyától származik. Ezért a transzpozonok kifejeződését petefészkekben vizsgáltam, hiszen a petefészek sejtjeiben aktív transzkripció zajlik. Emiatt az embriónál megfelelőbb vizsgálati szervnek tűnt, annak ellenére, hogy a petefészek egy heterogén szövet, melyben olyan sejtek is találhatók (testi sejtek), amelyekben a szomatikus $\mathrm{H} 1$ az egyetlen linker hiszton. Az RNS-szint méréshez Czech és mtsai (66) munkája alapján szövetspecificitás szerint csoportokra osztott transzpozonok közül választottam úgy, hogy legyen közöttük mindegyik kategóriába eső. Tizennégy transzpozon RNS mennyiségét mértem meg, melyek közül hét ivarvonal-specifikus, négy intermedier, három pedig szóma-specifikus kifejeződési mintázatot mutat. A HHH állatok petefészkében nyolc esetben szignifikáns eltérést tapasztaltam a vad típushoz képest, vagyis legalább kétszeres RNS-szint csökkenést vagy növekedést. A nyolc transzpozonból öt mutatott RNS mennyiség növekedést a $H H H$ állatokban, melyek közül négy ivarvonal-specifikus (HMSBeagle, Burdock, accord, Het-A), egy intermedier (blood); három transzpozon esetében pedig jelentős RNS-szint csökkenést tapasztaltam a $H H H$ állatok petefészkeiben, melyek közül egy ivarvonal-specifikus (297), kettő pedig intermedier (idefix, 412) (16A. ábra). A legnagyobb eltéréseket a HMS-Beagle, Burdock és Het-A transzpozonok mutatták, amelyeknél a legjelentősebb volt az RNS mennyiség növekedése a HHH mutáns petefészkekben, illetve a 412 transzpozon, melyben a legjelentősebb volt az RNS mennyiség csökkenés. A mért változások számszerüsített adatait a 16B. ábra mutatja. A mérések alapján elmondható, hogy az RNS-szintben tapasztalható változások nem specifikusak egy adott transzpozon csoportra, hiszen ivarvonal-specifikus és intermedier típusú 
transzpozonok is mutattak a vad típustól szignifikáns eltéréseket a $H H H$ mutáns petefészkekben. A szomatikus transzpozonok nem mutattak jelentős változást, azonban nem kizárható, hogy további transzpozonok kísérletbe bevonásával tapasztalnánk különbségeket. A mérési adatokból arra következtetek, hogy a BigH1 és H1 linker hisztonok jelenlétében a génexpressziós program eltéréseket mutat.

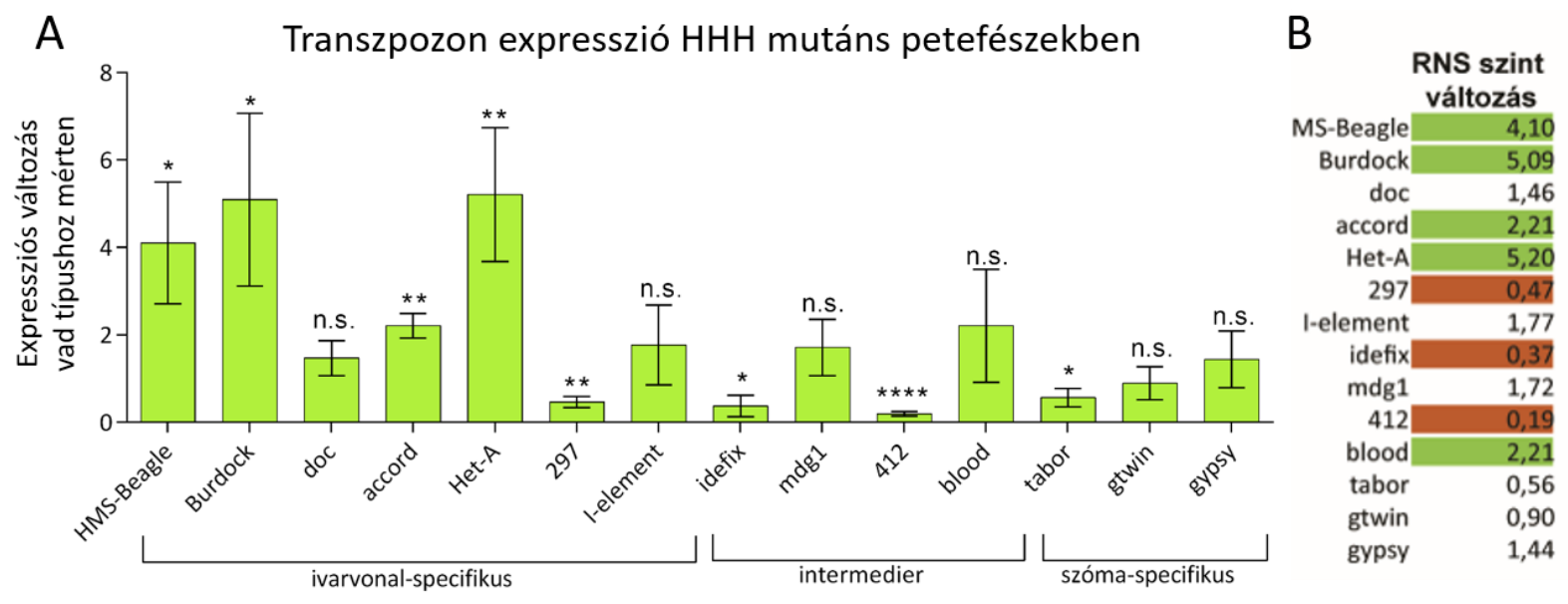

16. ábra. Transzpozon RNS-ek mennyisége eltéréseket mutat $H H H$ mutáns petefészkekben a vad típusú kontrollhoz képest. A) Transzpozon RNS-ek szintjének változása a $H H H$ mutáns állatokból származó petefészkekben, vad típusú állatok petefészkéhez viszonyítva (kísérletenként páronkénti összehasonlítással, ahol a vad típusú kontrollban mért értéket 1-nek vettem). A hibasávok reprezentálják a szórást (standard deviation). Statisztikai értékelés: t-próba (two-tailed, unpaired). pértékek: n.s. $=$ nem szignifikáns, ${ }^{*} \leq 0.05,{ }^{* *} \leq 0.01,{ }^{* * * *} \leq 0.0001$. B) A grafikonon feltüntetett, $H H H$ mutáns petefészkekben mért RNS-szint értékek számadatai. A vad típushoz képest legalább kétszeres növekedést mutató értékek zölddel, a legalább felére csökkenést mutatók pirossal vannak jelölve. Az ábra három független biológiai mintán végzett 2-2 technikai párhuzamos mérés eredményét mutatja be.

\subsection{A kromatinszerkezet nukleoszóma szinten hasonló a vad típusban és $H H H$ mutánsban}

Az embrionális fejlődés egyik kitüntetett eseménye hogy a fejlődő egyed saját genomja transzkripciósan aktiválódik. Ezt jelenti a maternális-zigótikus tranzíció, amelyhez az embrió kromatinszerkezete jelentősen átalakul (79). A tranzícióval együtt jár, vagy lehet, hogy annak egyik elindítója a linker hiszton BigH1-röl H1-re történő cseréje. Ez arra utal, hogy a két linker hiszton különböző kromatinszerkezet 
kialakítását teszi lehetővé. Célunk annak vizsgálata volt, hogy a kromatinszerkezetben lezajló változás során a BigH1 és $\mathrm{H} 1$ fehérjék hogyan befolyásolják a nukleoszóma szintű kromatinszerveződést a korai embrióban. H2Av-GFP fehérjét kifejező vad típusú és $H H H$ mutáns embriók in vivo videómikroszkópiás vizsgálatával kimutattuk, hogy a BigH1 helyettesítése H1-gyel a magok méretének megnövekedését okozza a vad típushoz képest (17. ábra) (62). Ez a különbség megfigyelhető az NC (nuclear cycle) 10-13 magi ciklusokban, habár egyre kisebb mértékben. Így a cellularizálódáshoz közeledve már nem olyan kifejezett a vad típusú és mutáns magok méretbeli különbsége. A méretbeli különbség hátterében állhat a kromatinszerkezet megváltozása, hiszen a lazább kromatinszerveződés nagyobb térfogatigénnyel, következésképpen nagyobb sejtmagokkal járhat. Ennek a feltételezésnek a bizonyítására a kétféle linker hiszton jelenlétében képződő kromatinszerveződés különbségeit vizsgáltuk. Az én feladatom ebben a mikrokokkális nukleáz (MNáz) enzimmel végezhető kromatinszerkezet vizsgálati módszerének beállítása és alkalmazása volt. Az MNáz-esszé gyakran használt technika a kromatin hozzáférhetőségének elemzésére. Alapja az, hogy a duplaszálú DNS törések létrehozására képes enzim hasításától a nukleoszómák vagy a DNS-kötő fehérjék megvédik a DNS-t. Így megfelelő körülmények mellett végzett MNáz kezelést követően a DNS vizsgálatával megállapítható, hogy mekkora hányada volt nukleoszómával védett és milyen a védett és nem védett részek kiterjedése. 


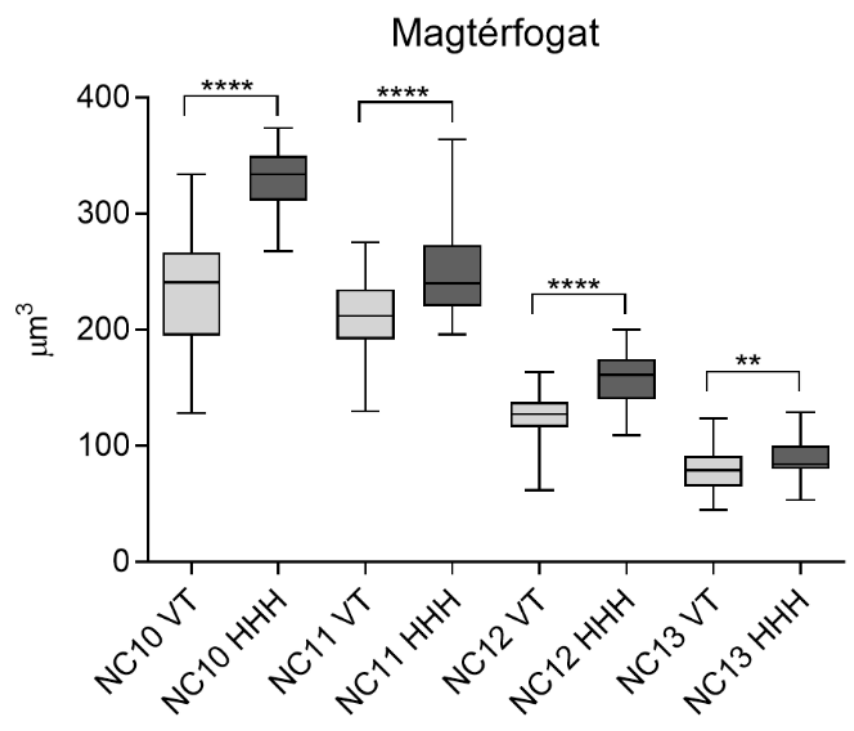

17. ábra. A $H H H$ mutáns embriókban a cellularizációt megelőző magi ciklusokban nagyobb a magok térfogata a vad típushoz képest. A magtérfogat kiszámításához a magok legnagyobb átmérőjét megmértük, majd a $V=\frac{4}{3} \pi r^{3}$ képlet segítségével adtuk meg a térfogatot. A méréseket az S-fázis során (két perccel a mitózist követően) végeztük, genotípusonként 3-3 embrión, 21-60 mag átmérőjét lemérve. A hibasávok reprezentálják a szórást (standard deviation). Statisztikai értékelés: t-próba (two-tailed, unpaired). p-értékek: ${ }^{* *} \leq 0.01,{ }^{* * *} \leq 0.0001$.

Kísérleteimmel a BigH1, illetve $\mathrm{H} 1$ jelenlétében létrejött nukleoszómákat alkotó DNS méretét és a nukleoszómák egymástól való távolságát határoztam meg, illetve a kromatin általános hozzáférhetőségét elemeztem. Ennek érdekében megvizsgáltam az MNáz emésztés eredményeként keletkezett mono- és multinukleoszómális DNS fragmentumok méretét, a nukleoszómák közötti linker DNS hosszát és a mononukleoszómális DNS fragmentumok arányát vad típusban és a $H H H$ mutánsban. A kísérleteket preblasztoderma stádiumú embriókból izolált kromatint használva végeztem, mivel ebben az állapotban a vad típus esetében csak BigH1, a HHH esetében pedig csak a BigH1 mintázatában kifejeződő H1 linker hiszton van jelen a kromatinon. A megemésztett kromatin mintákat Bioanalyzer chipen futtattam meg, amelynek segítségével bázispár felbontással megkaptam a DNS molekulák méretét (1. Függelék ábra).

Megállapítottam, hogy a vad típusú korai embriókban a mononukleoszómális DNS átlagosan 5, a dinukleoszómális DNS 10, a trinukleoszómális DNS 17 bázispárral hosszabb, mint a $H H H$ mutáns korai embriókban. (18A. ábra), a 
különbség tehát nukleoszómánként körülbelül $5 \mathrm{bp}$. Ennek hátterében az állhat, hogy a nagyobb méretü BigH1 fehérje a nukleoszómákból be- és kilépő DNS nagyobb részét védi meg az MNáz emésztés elöl. Ennek ellenére a linker DNS hosszában nem tapasztaltam eltérést, tehát a nukleoszómák egymástól való távolságát nem befolyásolja a linker hiszton típusa (18A. ábra). $\mathrm{A}$ tetranukleoszómális DNS fragmentumok mennyisége az egyes minták teljes DNS tartalmához képest nagyon alacsony volt, így a Bioanalyzer futtatás eredményeként kapott tetranukleoszómális DNS csúcs ellaposodó és nehezen elkülöníthető (Függelék 1A. ábra). Emiatt a különbség ebben a tekintetben nehezen volt mérhetö a vad típus és HHH mutáns között.

Ahhoz, hogy a kromatin hozzáférhetőségét összehasonlítsam, meghatároztam a mono- és multinukleoszómális DNS arányát a vad típusú és $H H H$ mutáns embrionális kromatinban is. Ebből az arányból a kromatin általános hozzáférhetöségére tudunk következtetni, mivel a magasabb mononukleoszómális DNS arány az MNáz enzim számára hozzáférhetöbb kromatinra utal (a technika ilyen jellegủ alkalmazását bemutatja (80)). A vad típusú és a $H H H$ mutáns korai embriókat összehasonlítva nem találtam jelentős különbséget a mono- és multinukleoszómális DNS arányát tekintve (18B. ábra), tehát valószínüsítem, hogy a $H H H$ mutánsban a nagyobb magméret nem a kromatin ún. gyöngyfüzér („beadson-string") szintű szerveződésének megváltozásából ered. 
A

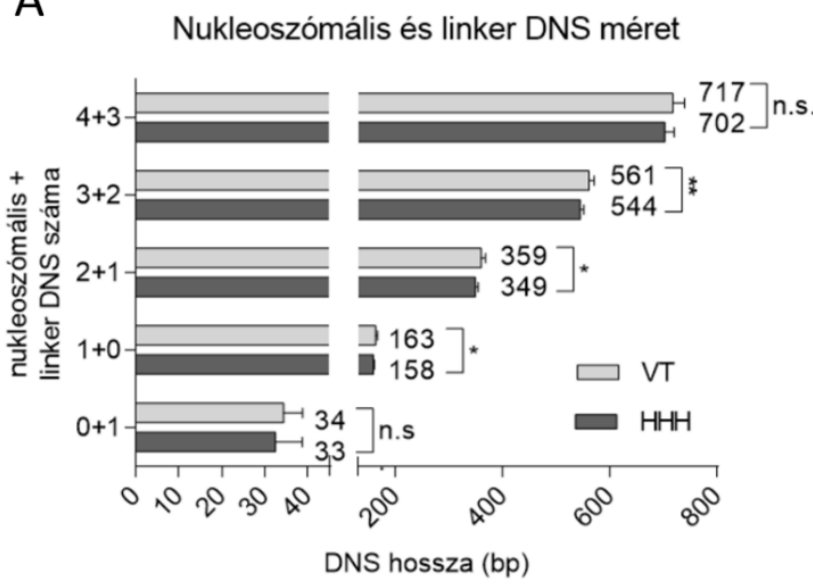

B

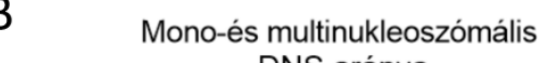
DNS aránya

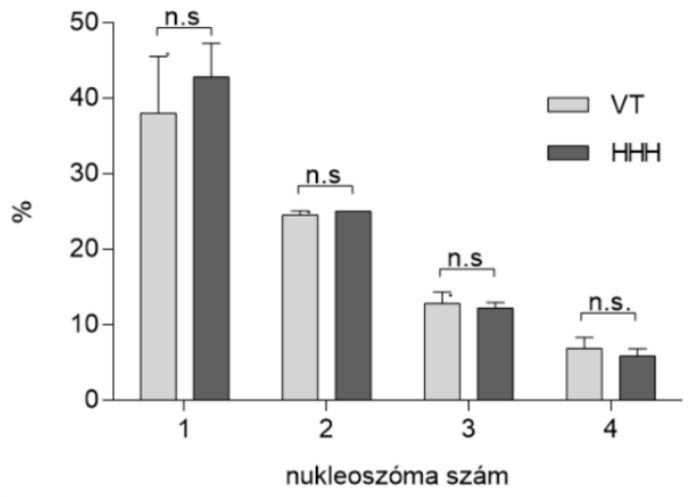

18. ábra. A kromatin hozzáférhetősége nem mutat szignifikáns eltérést a vad típusú és $\boldsymbol{H H H}$ mutáns embriókban. Vad típusú (VT) és HHH mutáns embriókból preparált kromatinon elvégzett MNáz-esszé kísérletek eredménye. A) Mono- és multinukleoszómális DNS, illetve linker DNS mérete a kromatin emésztését követően, Bioanalyzer DNA 1000 chip segítségével meghatározva. B) Kromatin hozzáférhetőségének vizsgálata az emésztés eredményeként létrejövő mono- és multinukleoszómális DNS arányának meghatározásával VT és HHH mutáns embrionális kromatin minták között. A hibasávok jelölik a szórást (standard deviation). Statisztikai értékelés: t-próba (twotailed, unpaired). p-értékek: n.s. $=$ nem szignifikáns, ${ }^{*} \leq 0.05,{ }^{* *} \leq 0.01$. Az ábra három független biológiai minta 2-2 párhuzamos futtatásának eredményét mutatja be.

\subsection{A BigH1 jelenlétében stabilabbak a nukleoszómák}

A kromatin nukleoszóma szintű szerveződése tehát nagymértékü hasonlóságot mutat BigH1 és $\mathrm{H} 1$ jelenlétében, így az nem lehet felelős a vad típus és $H H H$ mutáns közötti fenotípusos különbségekért. A BigH1 és $\mathrm{H} 1$ fehérjék aminosav-szekvenciájukat tekintve rendkívül eltérnek egymástól, ami felveti annak lehetőségét, hogy eltérő módon hatnak kölcsön a nukleoszómákkal. Következő célunk annak feltérképezése volt, hogy a linker hiszton típusa befolyásolja-e a nukleoszómák stabilitását. Ennek felderítésére két módszert alkalmaztam, melyekkel a nukleoszóma stabilitás annak meghatározásával vizsgálható, hogy milyen sókoncentrációjú oldattal végzett mosással bonthatók meg ezek a fehérje komplexek.

Az egyik eljárás a QINESIn esszé (Quantitative Imaging of Nuclei after Elution with Salt/Intercalators) volt. Ez az in situ mérési módszer lehetővé teszi a nukleoszómák stabilitásának vizsgálatát izolált sejtmagokban. A technikát emlős 
sejtvonalakból származó sejtmagokra dolgozták ki, amelyek viszonylag könnyen izolálhatók és kvantitálhatók, emiatt a módszert szükséges volt 0,5-2,5 órás Drosophila embriókból kinyert sejtmagokra optimalizálnom. A kísérletben olyan genotípusú (H2Av-GFP;+, illetve H2Av-GFP; HHH) embriókat használtam, melyekben a transzgenikus $\mathrm{H} 2 \mathrm{Av}$ core hiszton fehérje GFP fluoreszcens taggel volt ellátva, így a nukleoszómák dinamikáját a GFP jelen keresztül követhettem. A mérés alapja röviden, hogy a magokat beágyaztam agarózba és permeabilizáltam, majd növekvő sókoncentrációjú oldatokkal kezeltem. A magokat fixáltam, majd propídium-jodiddal $(\mathrm{PI})$ festettem a DNS-üket. A beágyazott mintákat ezt követően Spinning Disk konfokális mikroszkóppal vizsgáltam, és nyomon követtem a H2Av hiszton fehérje sódependens távozását a kromatinról. Mivel a propídium-jodid megfesti a magokat a DNS jelölésével, a GFP és a propídium-jodid jel együttes jelenléte információt ad arról, hogy a H2Av milyen mértékben távozott a kromatinról a sókezelés hatására, amely a nukleoszómák stabilitására utal. Összesen négy kísérletet végeztem el, melyekben megvizsgáltam, hogy $\mathrm{H} 1(H H H)$, illetve BigH1 (VT) jelenlétében miként változik a nukleoszóma stabilitás sókezelés hatására. A sejtmagokról készített mikroszkópos felvételeket a módszert kidolgozó Sejtbiológia kutatócsoportban (Debreceni Egyetem) értékelték ki, (65) alapján.

Az elsődleges és legfontosabb megfigyelés, hogy mind a négy kísérlet ugyanazt a tendenciát mutatja, miszerint a H2Av könnyebben leválik a kromatinról a $H H H$ mutáns embriókból származó magokban. A vad típus és a $H H H$ mutáns közötti legkisebb különbséget az első (19A. ábra), legnagyobbat pedig a második (19B. ábra) kísérlet mutatja. Azt tapasztaltam, hogy az egyes koncentrációkhoz tartozó mérések SEM értéke (standard error of the mean, középérték közepes hibája) meglehetősen alacsony, vagyis a koncentrációnként egyedileg lemért magok hasonlóan reagáltak a sókezelésre. A harmadik és negyedik kísérletekben (19C-B. ábra), amelyek a leginkább hasonlítanak egymásra, a legnagyobb eltérést vad típus és $H H H$ mutáns között a $800 \mathrm{mM}$ sókoncentrációnál tapasztaltam. Mindkét esetben jelentősen alacsonyabb a normalizált fluoreszcencia intenzitás a $H H H$ típusú magokban, vagyis a kromatinkötött H2Av mennyisége. Ez azt jelenti, hogy bár a core hisztonok meglehetősen magas sókoncentrációval távolíthatók el, a szomatikus $\mathrm{H} 1$-et tartalmazó kromatinból könnyebben eluálhatók, mint a BigH1 linker hisztont tartalmazó a kromatinból. A QINESIn esszék összesített eredménye 
tehát azt mutatja, hogy azok a nukleoszómák, amelyek BigH1 jelenlétében jönnek létre, stabilabbak, mint a szomatikus $\mathrm{H} 1$ jelenlétében kialakulók.
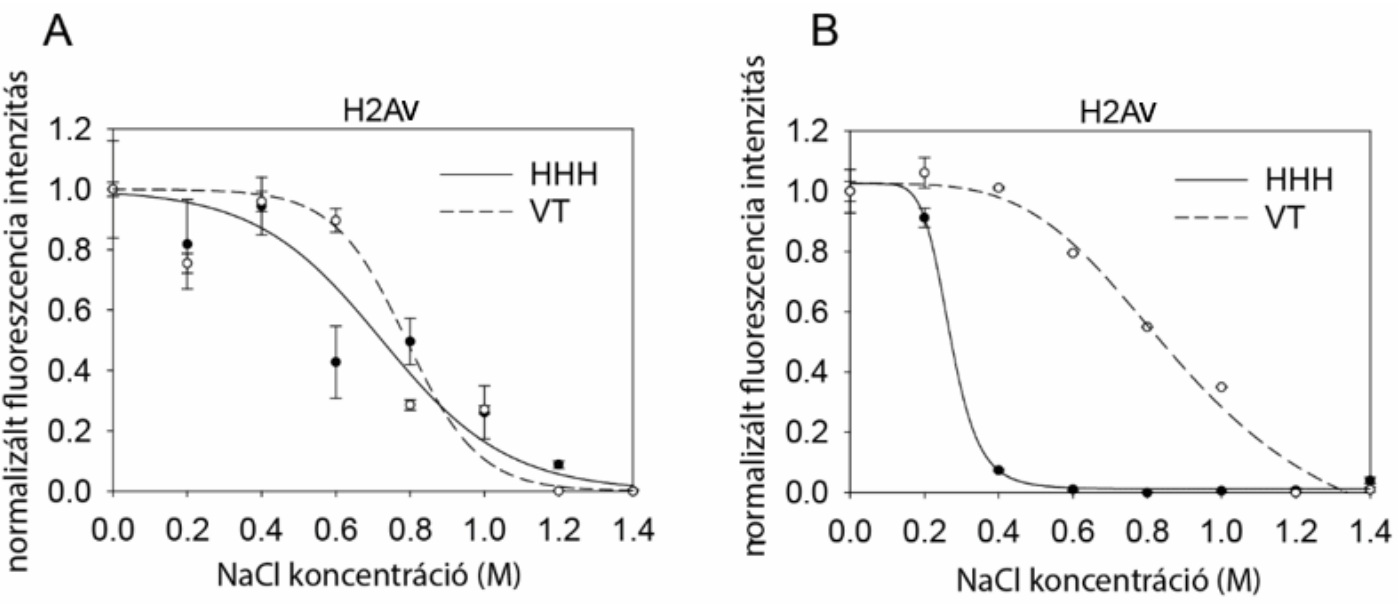

C
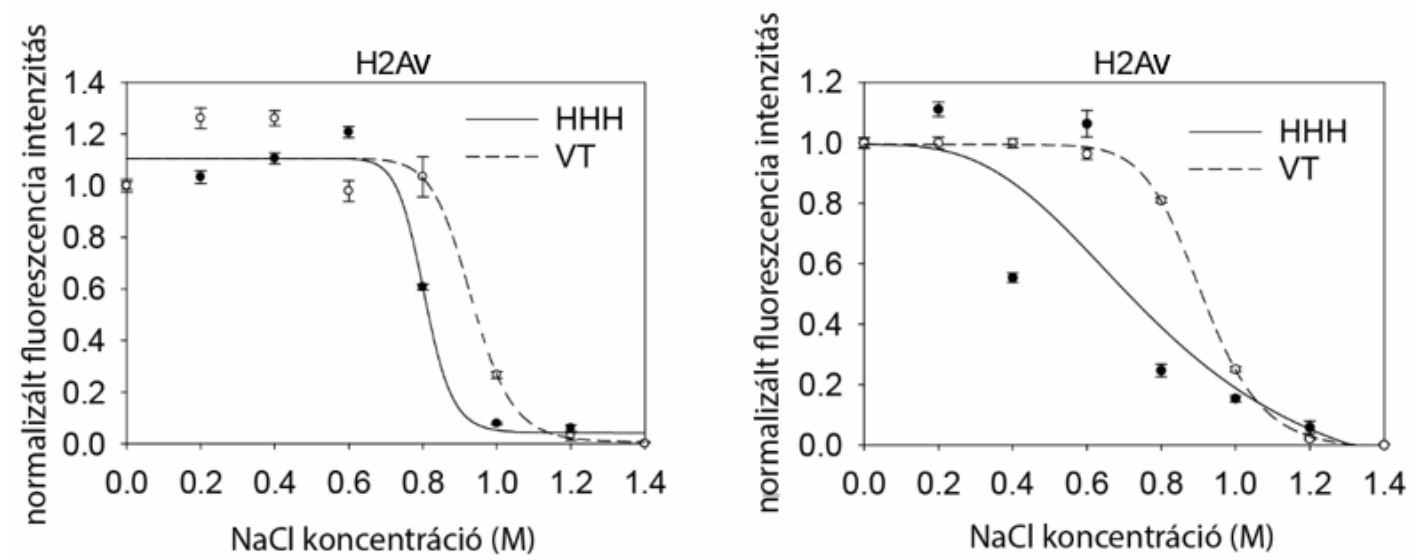

19. ábra. A BigH1-et tartalmazó nukleoszómák stabilabbak a $\mathrm{H} 1$ jelenlétében kialakult nukleoszómáknál. A-D) Négy független QINESIn vizsgálat eredménye. A grafikonok a H2Av-GFP transzgénröl származó jel normalizált fluoreszcencia intenzitását mutatják a $\mathrm{NaCl}$ koncentráció függvényében, $H 2 A v-G F P ;+(V T)$ és $H 2 A v-G F P ; H H H(H H H)$ embriókból preparált magokban.

Eredményeim validálására egy másik módszert is alkalmaztam, amelynek segítségével a H3 és H4 core hisztonok kromatinról történő elúcióját vizsgáltam sókezelés hatására. Mivel nem állt rendelkezésemre olyan Drosophila vonal, amelyben ezek a fehérjék jelölt formában voltak jelen, így egy Western blot alapú módszert terveztem, ami lehetővé teszi a két core hiszton antitestekkel való kimutatását. A kísérlethez preblasztoderma stádiumú embriókból izoláltam kromatint, amelyet $800 \mathrm{mM} \mathrm{NaCl}$-ot tartalmazó oldattal kezeltem. Választásom azért 
erre a sókoncentrációra esett, mert a QINESIn stabilitás esszében ennél a koncentrációnál tapasztaltam a legnagyobb különbséget a vad típus és $H H H$ mutáns között. Elkülönítettem a sókezelés előtt nem kromatinkötött, illetve a sókezelés után a sóeluált és kromatinkötött fehérjefrakciókat, amelyekböl antitesteket használva kimutattam a H3 és H4 fehérjéket. Azt tapasztaltam, hogy mind a $\mathrm{H} 3$, mind a $\mathrm{H} 4$ core hisztonok nagyobb arányban eluálhatók a $H H H$ embriókból származó kromatinról a vad típushoz képest (20. ábra). Így tehát ez a kísérlet megerősíti, hogy a BigH1 jelenlétében létrejött nukleoszómák sókezeléssel szemben nagyobb stabilitást mutatnak.

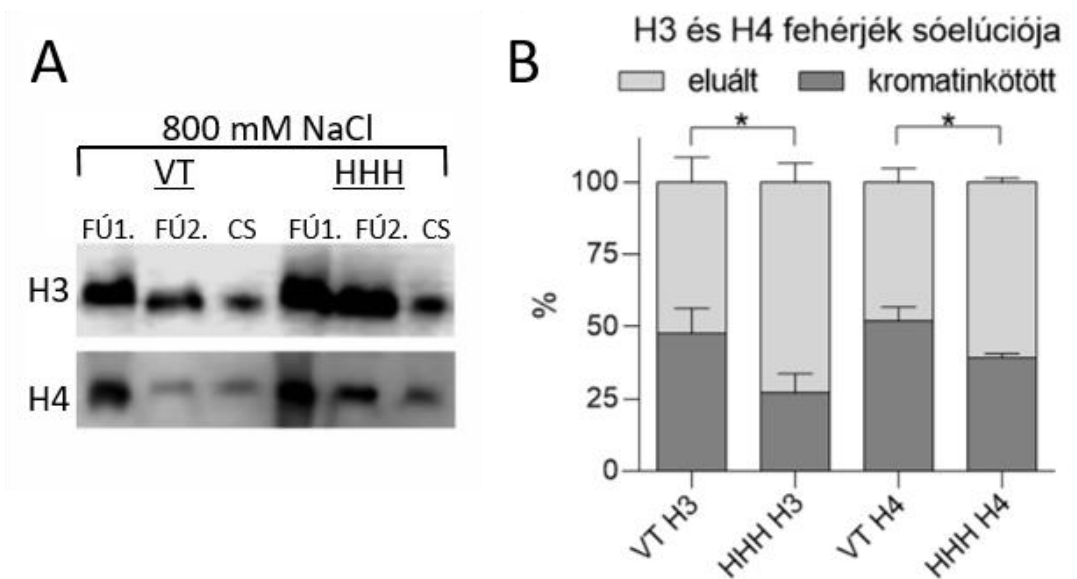

20. ábra. A BigH1-et tartalmazó nukleoszómák stabilabbak a $\mathrm{H} 1$ jelenlétében kialakult nukleoszómáknál. H3 és H4 core hisztonok elúciója VT (3xFLAG jelölt BigH1, 3F) és $H H H$ mutáns embriókból származó kromatinról, $800 \mathrm{mM} \mathrm{NaCl}$ kezeléssel. A) Reprezentatív Western blot, ahol a FÚ1. (felülúszó 1.) a sókezelést megelőzően nem kromatinkötött fehérjefrakció, a FÚ2. (felülúszó 2.) a sókezelést követően a kromatinról eluált fehérjefrakció, a CS (csapadék) a sókezelést követően a kromatinkötött fehérjefrakció. B) Az elvégzett kísérletek statisztikai értékelése (három, független biológiai mintákon végzett kísérletek eredménye alapján). A hibasávok jelölik a szórást (standard deviation). Statisztikai értékelés: t-próba (two-tailed, unpaired). p-érték: * $\leq 0.05$.

\subsection{A BigH1 könnyebben eltávolítható a kromatinról, mint a H1}

A BigH1, illetve $\mathrm{H} 1$ jelentében kialakuló nukleoszómák stabilitásának különbségeit tekintve feltételezhető, hogy ez a kromatoszómák stabilitásával összhangban van. A következő kísérletet abból a célból terveztem, hogy a BigH1 és H1 kromatinról történő elúcióját vizsgáljam sókezelés hatására, ami a kromatoszómák stabilitásáról ad információt. Mivel a linker hisztonok kölcsönhatása 
a DNS-sel gyengébb, mint a core hisztonoké, ezért alacsonyabb sókoncentrációt használtam ebben a kísérletsorozatban (81). A H3 és H4 core hisztonokhoz hasonlóan a linker hisztonok vizsgálatára is Western blottot alkalmaztam. A Western blot kísérletet kétféle embrió mintán végeztem el. Az egyik mintában olyan heterozigóta nőstény állatok embriói voltak, melyekben a harmadik kromoszómapár egyikén a vad típusú FLAG-jelölt BigH1, másikán a HHHallélt hordozták (3F/HHH). Ezekben az embriókban 3x FLAG epitóp taggel ellátott, de különböző méretü linker hisztonok termelődnek. A másik mintában vad típusú BigH1-et termelő és $H H H$ homozigóta embriókat kevertem össze azonos arányban $(3 F+H H H)$. Az ilyen típusú minták vizsgálata azt is lehetővé tette, hogy következtetést vonjak le a kétféle linker hiszton közötti kompetícióval kapcsolatban.

Az eredményeket tekintve több észrevételt tettem. Először is, a kevert és heterozigóta embriókon készült Western blottokon is megfigyelhető, hogy a $\mathrm{HHH}$ allélról származó H1 mennyisége sokkal alacsonyabb, mint a vad típusú allélról származó BigH1 fehérjéé. A korábbi kísérletek alapján ez a két fehérje $\mathrm{N}$ terminálisának különbségeiből fakad. Ezen felül arra is utal, hogy a két fehérje expressziója egymástól független, ugyanis a kétféle mintában hasonló mennyiségü $\mathrm{H} 1$, illetve BigH1 mutatható ki (21A. ábra). Továbbá, a BigH1 jelentős része nem kromatinkötött, hanem szabad formában van jelen, amiből arra következtetek, hogy a BigH1 nagy feleslegben termelödik. Ezzel szemben a kis mennyiségben termelődő $H 1$ jórésze kromatinkötött. Ez a $3 F+H H H$ kevert mintákban látványosabb, hiszen ezekben $3 F$ homozigóta és $H H H$ homozigóta embriók kromatinját vizsgáltam, és a $H H H$ homozigóta állatokban a $\mathrm{H} 1$ az egyetlen linker hiszton. Ugyancsak megfigyeltem, hogy a BigH1 és a szomatikus $\mathrm{H} 1$ hasonló arányban található meg kromatinkötött formában a $3 F+H H H$ és a $3 F / H H H$ mintákban is, ami arra utal, hogy a nagy mennyiségben termelődő BigH1 nem szorítja le a kis mennyiségben jelen lévő $\mathrm{H} 1$ fehérjét a kromatinról (21B. ábra). Továbbá, a szomatikus $\mathrm{H} 1$ az alkalmazott sókezelések hatására kisebb mennyiségben távozik a kromatinról, mint a BigH1, annak ellenére, hogy jelentősen alacsonyabb mennyiségben van jelen (21C-D. ábra). Ebböl arra következtetek, hogy a $\mathrm{H} 1$ erősebben kapcsolódik a nukleoszómákhoz, és az így létrejött kromatoszómák stabilabbak. 


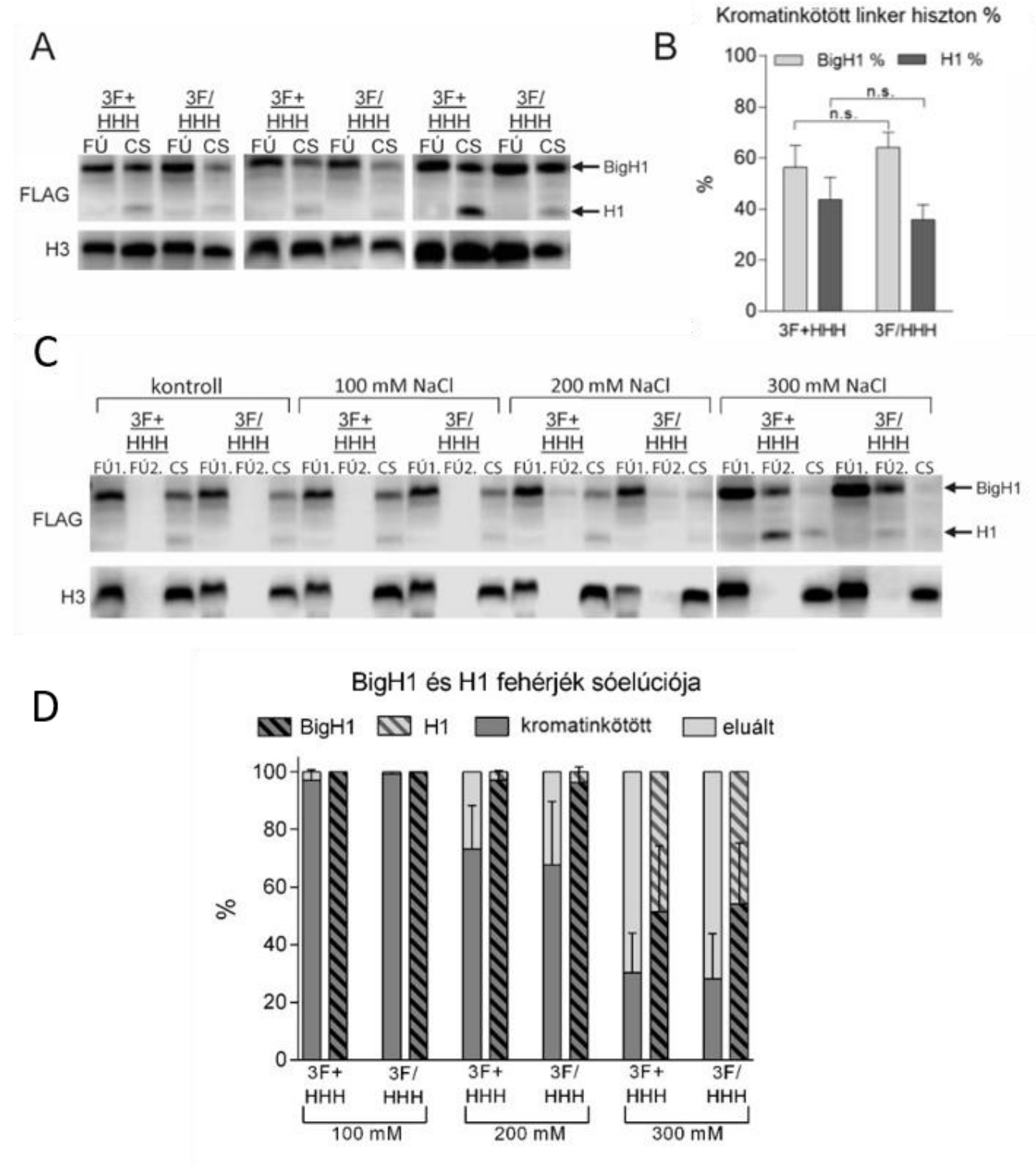

21. ábra. A BigH1 linker hiszton gyengébben kapcsolódik a nukleoszómákhoz, mint a H1, és azokról könnyebben eltávolítható. A) Western blot a 3F allélról származó 3X FLAG taggel jelölt BigH1 és a $H H H$ allélról származó $H 1$ fehérjék kimutatásáról anti-FLAG ellenanyaggal. A H3 core hiszton belső kontrollt anti-H3 ellenanyaggal detektáltam. Az ábra három független biológiai mintán végzett kísérletet mutat be. $\mathrm{B})$ Kromatinkötött $\mathrm{BigH} 1$ és $\mathrm{H} 1$ linker hisztonok aránya $3 F+H H H$ kevert és $3 F / H H H$ heterozigóta embriókból származó kromatin preparátumban, az A) ábrarészen bemutatott Western blot eredmények alapján. C) Western blot a kontroll (15 $\mathrm{mM} \mathrm{NaCl}$ ) és sókezelt kromatin mintákból anti-FLAG ellenanyaggal kimutatott BigH1 (3F allélról) és H1 ( $H H H$ allélról) linker hisztonok megoszlásáról különböző kromatinfrakciókban (FÚ1.: felülúszó 1., nem kromatinkötött frakció a sókezelést megelőzően; FÚ2.: felülúszó 2., kromatinról eluált frakció a sókezelést követően; CS: csapadék, kromatinkötött frakció a sókezelést követöen). D) Sókezelés után kromatinkötött és eluált BigH1 és $\mathrm{H} 1$ fehérje aránya $3 F+H H H$ kevert és $3 F / H H H$ heterozigóta embriókból származó kromatin mintákban, Western blot alapján (három, független biológiai mintákon végzett kísérletek eredménye). A hibasávok jelölik a szórást (standard deviation). Statisztikai értékelés: t-próba (twotailed, unpaired). p-értékek: n.s.=nem szignifikáns. 
Az eltérő kromatoszóma és nukleoszóma stabilitás jelentőségének in vivo vizsgálatára FRAP (Fluorescence Recovery After Photobleaching) kísérletet végeztünk élő vad típusú és $H H H$ mutáns embriókon. A vizsgálatokban $H 2 A v$ GFP;+, illetve H2Av-GFP; HHH preblasztoderma stádiumú embriókat alkalmaztunk, és ezekben in vivo követtük a H2Av-GFP transzgénröl eredö fluoreszcens jel változásának dinamikáját a sejtciklus S-fázisban. Az eredmények azt mutatták, hogy a vad típusú embriókban, amelyekben a BigH1 a linker hiszton, sokkal gyorsabban állt helyre a fluoreszcencia a fakítást követően, mint a $H H H$ mutánsban (22A. ábra) (62). Emellett a $H H H$ mutáns embriókban nagyobb mennyiségben detektáltunk lipidcseppeket, melyekröl ismert, hogy core hisztonokat hordoznak (82) (22B-C. ábra). Ez arra utal, hogy a BigH1 dinamikusabb nukleoszóma kicserélődést tesz lehetővé, mint a szomatikus $\mathrm{H} 1$, és megerősíti a nukleoszóma és kromatoszóma stabilitási vizsgálatok eredményeit.
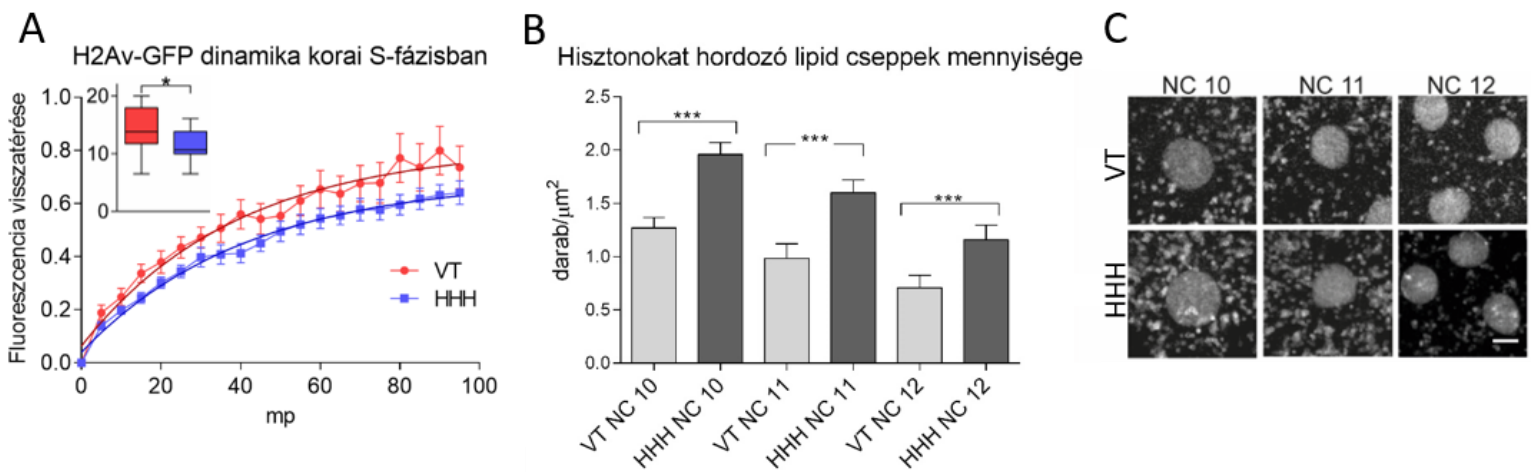

22. ábra. A BigH1 linker hiszton dinamikusabb nukleoszóma kicserélődést tesz lehetővé, mint a H1. A) H2Av-GFP;+ (VT) és H2Av-GFP; HHH (HHH) preblasztoderma stádiumú (NC 11-12) embriókon a sejtciklus S-fázisában végzett FRAP kísérlet eredménye (genotípusonként 12-12 magon végzett mérés). A grafikonon a H2Av-GFP transzgénről származó fluoreszcens jel visszatérése van feltüntetve az idő függvényében. A dobozdiagram az egyedi FRAP mérések görbe alatti terület értékét mutatja be az első 40 másodpercben, amikor a legdinamikusabb a nukleoszóma kicserélődés. A mérések Leica SP5 AOBS konfokális lézer pásztázó mikroszkóppal (40x objektív, NA: 0,75) és Leica FRAP Wizard programmal készültek. B) Lipidcseppek relatív mennyisége vad típusú (VT) és HHH mutáns embriókban az NC 10-12 magi ciklusokban (genotípusonként 12-12 $97,38 \mu \mathrm{m}^{2}$ területen történt mérés). A hibasávok jelölik a szórást (standard deviation). Statisztikai értékelés: t-próba (two-tailed, unpaired). p-értékek: ${ }^{*} \leq 0.05,{ }^{* * *} \leq 0.001$. C) Reprezentatív mikroszkópos kép a lipidcseppekröl vad típusú (VT) és $H H H$ mutáns embriókban a megadott magi ciklusokban. 


\subsection{A Drosophila H1 és BigH1 fehérjék aminosav-szekvenciája eltérő konzerváltságot mutat}

A BigH1 linker hiszton cseréje szomatikus H1-re Drosophila melanogaster korai embrióban számos fenotípussal jár, melyek azt mutatják, hogy bár a BigH1 normál laboratóriumi körülmények között $\left(25^{\circ} \mathrm{C}\right)$ nem létfontosságú az embrió fejlödéséhez, azonban szükséges annak optimális végbemeneteléhez, $15^{\circ} \mathrm{C}$-on pedig esszenciális. Annak vizsgálatára, hogy a fenotípusos különbségek vad típusú BigH1-et és BigH1 helyett H1-et hordozó állatok $(H H H)$ között visszavezethetők-e a linker hisztonok szerkezetbeli eltéréseire, térszerkezeti modellt készítettünk a $\mathrm{H} 1$ és BigH1 fehérjékről. Mindkét fehérje $\mathrm{N}$ - és C-terminális doménje rendezetlen szerkezetű, így ezen régiók szerkezete nem modellezhető pontosan. A centrális globuláris domén ismert szerkezetü linker hisztonnal való homológiáját kihasználva erröl a doménröl készítettünk szerkezeti modellt (62) (23A. ábra). A modelleket átfedésbe hoztuk a nukleoszóma térszerkezettel, amelynek segítségével a Drosophila linker hisztonokat összevethetjük a jobban jellemzett Gallus H5 hisztonnal (69). Így összehasonlíthatjuk azt is, hogy melyek azok a fehérjerégiók, amelyek a nukleoszómális DNS kötésében részt vehetnek.

A modellek vizsgálatával felfedeztük, hogy a szomatikus $\mathrm{H} 1$ fehérjében található egy hurok ( $\mathrm{L} 3,23 \mathrm{~B}$. ábra), ami a BigH1 fehérjében lényegesen megrövidült (23C. ábra). Az L3 hurkot alkotó aminosavakat a szomatikus H1-ben DNS kötésért felelős régióként írták le a szakirodalomban (24). A modell alapján arra következtethetünk, hogy a DNS-kötő hurok rövidülése miatt a BigH1 linker hiszton gyengébb kötést alakít ki a nukleoszómális DNS-sel, mint a szomatikus H1. Feltételezzük, hogy ez a megfigyelés, illetve a BigH1 és H1 linker hisztonok nagymértékben eltérő aminosav-összetétele (23D. ábra, 4. Függelék táblázat) lehet a felelős azokért a fenotípusokért, amelyeket a $H H H$ mutáns állatokban tapasztaltunk. 
A

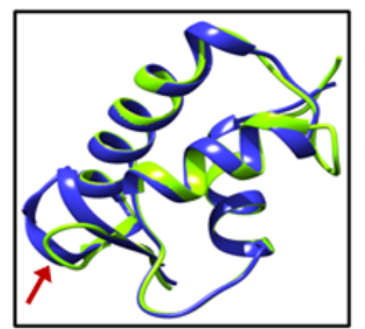

$\mathrm{dH} 1$
B

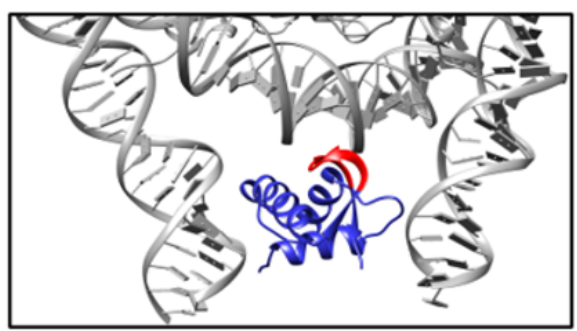

$\mathrm{dBigH} 1$
C

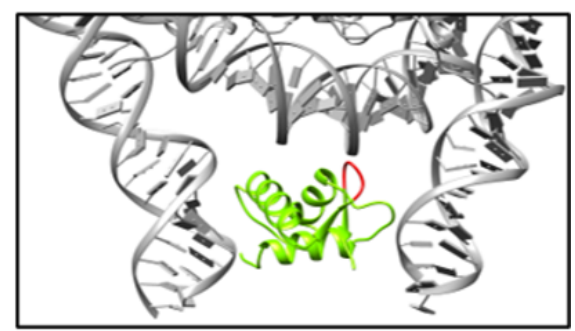

nukleoszómális DNS
C

\section{MELANOGASTER H1 AMINOSAV ÖSSZETÉTEL}

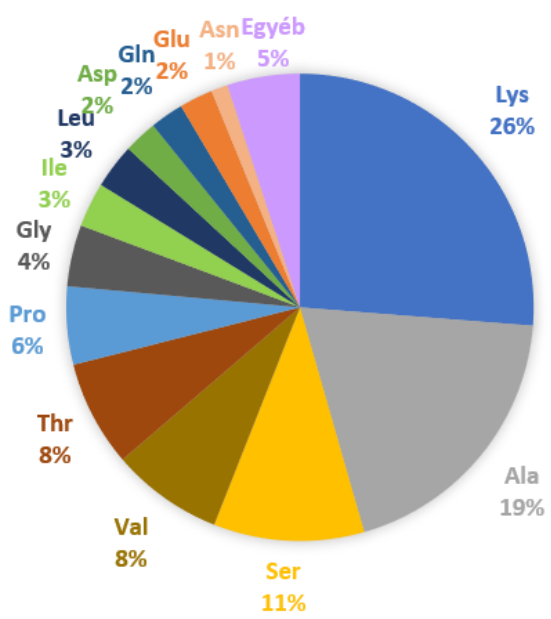

D

D. MELANOGASTER BIGH1 AMINOSAV ÖSSZETÉTEL

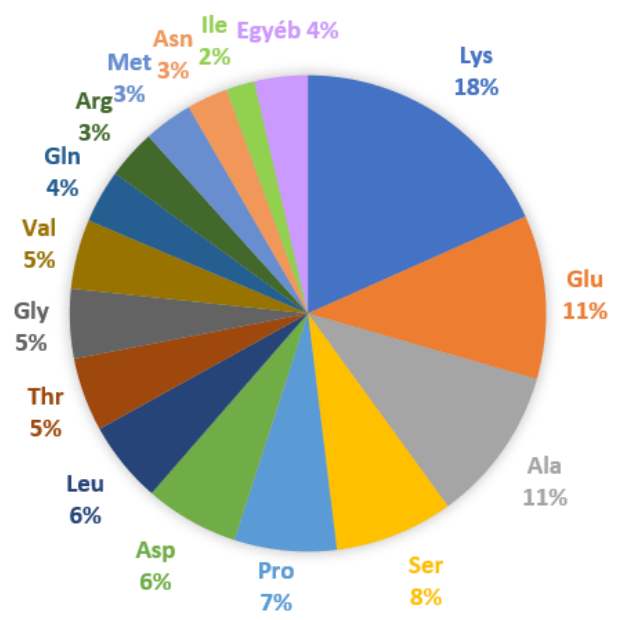

23. ábra. A BigH1 fehérjében megrövidül egy hurok, melyet a $\mathrm{H} 1$ fehérjében DNS-kötöként írtak le. A) H1 és BigH1 fehérjék szerkezeti modellje egymásra illesztve. Piros nyíl jelöli az L3 hurkot. B) A H1 linker hiszton nukleoszóma modellbe illesztve, a DNS kötésben szerepet játszó L3 hurok kiemelésével. C) A BigH1 linker hiszton nukleoszóma modellbe illesztve, kiemelve az azonos pozíciót. C) D. melanogaster $\mathrm{H} 1$ linker hiszton aminosav-összetétele. D) D. melanogaster BigH1 linker hiszton aminosav-összetétele.

Az én feladatom volt annak vizsgálata, hogy az L3 DNS-kötő hurok hiánya a BigH1 fehérjében általános-e Drosophila fajok között. Ehhez tizenkét Drosophila fajban elérhető BigH1 és $\mathrm{H} 1$ fehérjeszekvenciát szereztem be (4. táblázat), melyeket egymáshoz illesztettem. Az L3 hurok minden vizsgált H1 fehérjében megtalálható, és minden vizsgált BigH1 fehérjében jelentősen megrövidül (24. ábra), tehát a hurok megrövidülése a BigH1 fehérje sajátosságának tekinthető, és konzervált jelleg. 
$\mathrm{H} 1$

$\mathrm{BigH} 1$

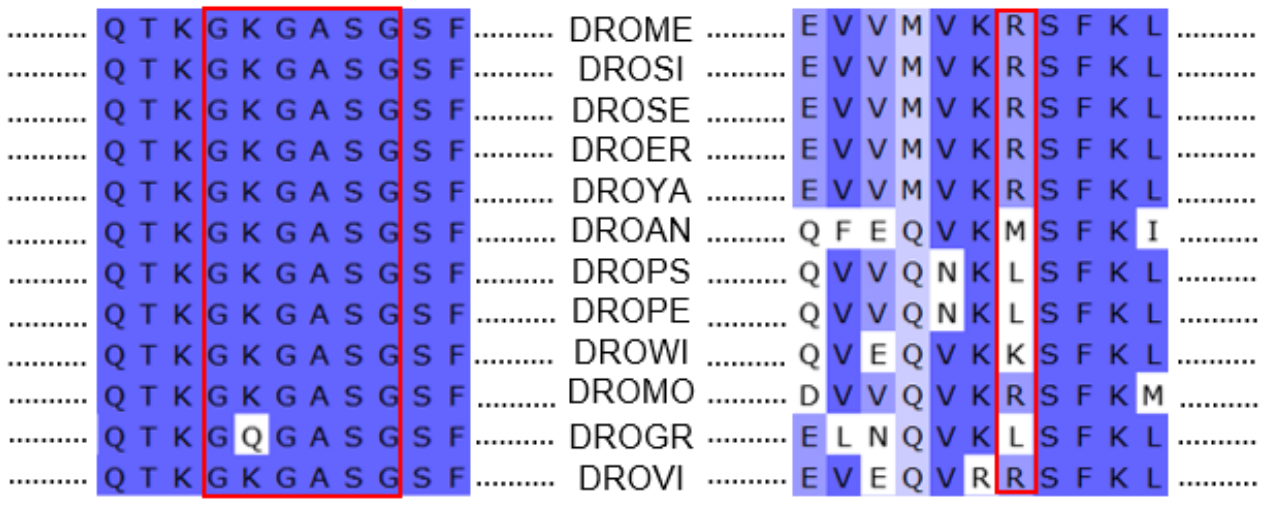

24. ábra. A globuláris doménben található L3 hurok a BigH1 fehérjében megrövidül. Piros keret jelöli a H1-ben a hurokot alkotó aminosavakat, a BigH1-ben pedig a pozíciót, ahonnan a hurok hiányzik. Az aminosavak színezésének erőssége a konszenzustól való eltérést mutatja (a világosabb szín nagyobb eltérést jelent).

A teljes hosszúságú BigH1 és H1 fehérjeszekvenciák hasonlóságának vizsgálatára újabb szekvencia illesztést végeztem Drosophila fajok BigH1 és H1 fehérjeszekvenciái között. A Drosophila willistoni, repleta, és Hawaii fajokban található BigH1 hiszton fehérjék szekvenciái olyan nagymértékben eltérnek a többi fajban megtalálhatóktól, hogy a teljes hosszúságú illesztés minőségét jelentősen rontják, ezért az illesztés során ezeket nem vettem figyelembe, és vizsgálataimat a D. melanogaster-hez közelebbi fajokra korlátoztam, a melanogaster és obscura alcsoportokra (25A. ábra). Azt tapasztaltam, hogy a H1 és BigH1 fehérjék szekvenciái között csak kismértékü $(<30 \%)$ hasonlóság fedezhető fel, annak ellenére, hogy a két fehérje hasonló funkcióval rendelkezik (25B. ábra). 


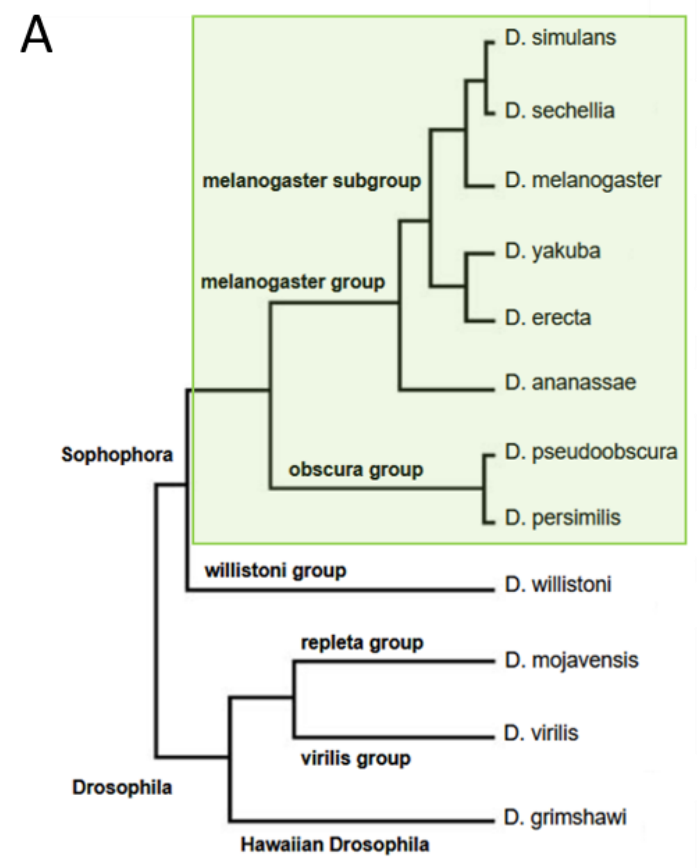

\begin{tabular}{|c|c|c|c|c|c|c|c|c|c|c|}
\hline \multirow[t]{2}{*}{$B$} & \multicolumn{10}{|c|}{$\begin{array}{c}\text { H1 és BigH1 fehérjeszekvenciák összehasonlítása különböző Drosophila } \\
\text { fajokban } \\
\text { H1 }\end{array}$} \\
\hline & & DROME & DROSI & DROSE & DROER & DROYA & DROAN & DROPS & DROPE & \multirow{9}{*}{$\begin{array}{r}100 \% \\
50 \% \\
0 \%\end{array}$} \\
\hline \multirow{8}{*}{ BigH1 } & DROME & $27 \%$ & $27 \%$ & $27 \%$ & $27 \%$ & $26 \%$ & $27 \%$ & $27 \%$ & $27 \%$ & \\
\hline & DROSI & $28 \%$ & $28 \%$ & $28 \%$ & $28 \%$ & $27 \%$ & $28 \%$ & $28 \%$ & $28 \%$ & \\
\hline & DROSE & $27 \%$ & $27 \%$ & $28 \%$ & $27 \%$ & $27 \%$ & $28 \%$ & $28 \%$ & $28 \%$ & \\
\hline & DROER & $27 \%$ & $27 \%$ & $28 \%$ & $27 \%$ & $26 \%$ & $27 \%$ & $27 \%$ & $27 \%$ & \\
\hline & DROYA & $27 \%$ & $28 \%$ & $28 \%$ & $27 \%$ & $27 \%$ & $28 \%$ & $27 \%$ & $27 \%$ & \\
\hline & DROAN & $27 \%$ & $27 \%$ & $28 \%$ & $27 \%$ & $26 \%$ & $28 \%$ & $28 \%$ & $28 \%$ & \\
\hline & DROPS & $20 \%$ & $20 \%$ & $20 \%$ & $20 \%$ & $19 \%$ & $20 \%$ & $20 \%$ & $20 \%$ & \\
\hline & DROPE & $19 \%$ & $19 \%$ & $19 \%$ & $18 \%$ & $18 \%$ & $19 \%$ & $19 \%$ & $19 \%$ & \\
\hline
\end{tabular}

25. ábra. A BigH1 és $\mathbf{H 1}$ fehérjék között kevesebb, mint $30 \%$ a hasonlóság. A) A zölddel bekeretezett fajokban megtalálható $H 1$, illetve BigH1 fehérjék szekvenciáit használtam fel a konzerváltság vizsgálatához. B) A teljes hosszúságú $\mathrm{H} 1$ és BigH1 fehérjeszekvenciák hasonlósága Drosophila fajok között, szekvencia illesztés alapján (távolsági mátrix). A fajnevek rövidítéseit a 4. táblázat tartalmazza.

Megvizsgáltam a BigH1 és $\mathrm{H} 1$ fehérjék fajok közötti konzerváltságát is. Ennek vizsgálatára szintén a különbözö Drosophila fajokban fellelhetö BigH1 és H1 fehérjeszekvenciák illesztését alkalmaztam. A melanogaster és obscura alcsoportban található nyolc fajból származó BigH1, illetve H1 fehérjeszekvenciákat egymáshoz illesztettem, majd az illesztés alapján megvizsgáltam a teljes fehérjék, illetve a globuláris domének konzerváltságát (26. ábra). 
Az illesztés eredményeként azt tapasztaltam, hogy a szomatikus $\mathrm{H} 1$ fehérje nagyobb mértékủ konzerváltságot mutat a vizsgált fajok között, mint a BigH1 (26AB. ábra), különösen a globuláris domén, amely esetében a vizsgált fajok közötti hasonlóság legalább 95\% (26C. ábra). A BigH1 fehérje közeli rokon fajok között szintén nagymértékủ hasonlóságot mutat (26D. ábra). A teljes fehérjét tekintve a $D$. melanogaster-hez legközelebbi rokon fajok, a $D$. simulans és $D$. sechellia esetén 90\% feletti hasonlóságot, a melanogaster alcsoportban pedig $80 \%$ feletti hasonlóságot mutat a BigH1 linker hiszton aminosav-szekvenciája a $D$. melanogaster-ben megtalálható variánshoz. A távoli rokon, de a melanogaster alcsoportba tartozó $D$. ananassae esetén ez a hasonlóság már $60 \%$ alatti, az obscura csoportban pedig már csupán 30-40\%. A globuláris domént vizsgálva hasonló tendenciát tapasztaltam (26E. ábra). Tehát, bár a BigH1 fehérje az általam vizsgált fajokban megtalálható, azonban a fehérje aminosav-szekvenciája kevésbé konzervált, mint a szomatikus $\mathrm{H} 1$ fehérjéé. Ugyanakkor az L3 hurok megrövidülése a BigH1 fehérje esetén konzervált jelleg. A C- és $\mathrm{N}$-terminális doménekre vonatkozó konzerváltsági adatokat az $\mathbf{5}$. Függelék táblázat tartalmazza. 
A

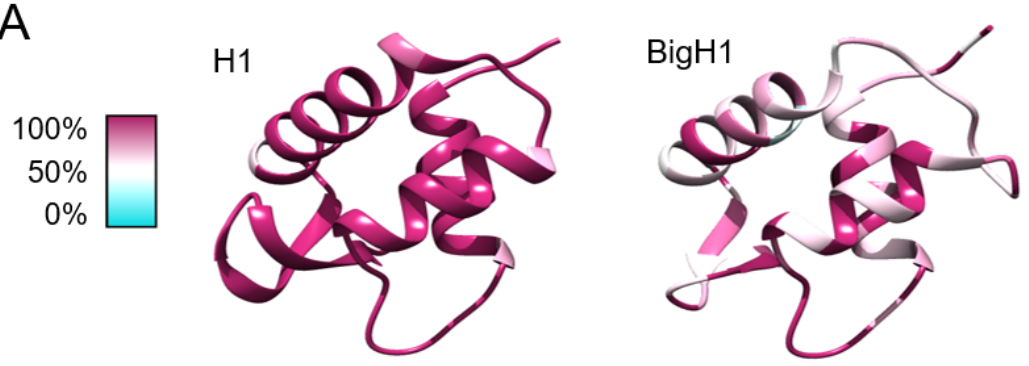

B H1 fehérjeszekvenciák összehasonlítása különböző Drosophila fajokban DROME DROSI DROSE DROER DROYA DROAN DROPS DROPE

\begin{tabular}{|c|c|c|c|c|c|c|c|c|}
\hline DROME & $100 \%$ & $95 \%$ & $94 \%$ & $89 \%$ & $91 \%$ & $81 \%$ & $75 \%$ & $74 \%$ \\
\hline DROSI & $95 \%$ & $100 \%$ & $96 \%$ & $89 \%$ & $89 \%$ & $80 \%$ & $73 \%$ & $72 \%$ \\
\hline DROSE & $94 \%$ & $96 \%$ & $100 \%$ & $88 \%$ & $88 \%$ & $78 \%$ & $72 \%$ & $71 \%$ \\
\hline DROE & $89 \%$ & $89 \%$ & $88 \%$ & $100 \%$ & $92 \%$ & $82 \%$ & $76 \%$ & $75 \%$ \\
\hline DROYA & $91 \%$ & $89 \%$ & $88 \%$ & $92 \%$ & $100 \%$ & $80 \%$ & $75 \%$ & $74 \%$ \\
\hline DROAN & $81 \%$ & $80 \%$ & $78 \%$ & $82 \%$ & $80 \%$ & $100 \%$ & $80 \%$ & $80 \%$ \\
\hline DROP & $75 \%$ & $73 \%$ & $72 \%$ & $76 \%$ & $75 \%$ & $80 \%$ & $100 \%$ & $99 \%$ \\
\hline DROF & $74 \%$ & $72 \%$ & $71 \%$ & $75 \%$ & $74 \%$ & $80 \%$ & $99 \%$ & $100 \%$ \\
\hline
\end{tabular}

C H1 globuláris doménszekvenciák összehasonlítása különböző Drosophila fajokban

DROME DROSI DROSE DROER DROYA DROAN DROPS DROPE

$\begin{array}{rrrrrrrrr}\text { DROME } & 100 \% & 100 \% & 99 \% & 100 \% & 100 \% & 99 \% & 96 \% & 96 \% \\ \text { DROSI } & 100 \% & 100 \% & 99 \% & 100 \% & 100 \% & 99 \% & 96 \% & 96 \% \\ \text { DROSE } & 99 \% & 99 \% & 100 \% & 99 \% & 99 \% & 97 \% & 95 \% & 95 \% \\ \text { DROER } & 100 \% & 100 \% & 99 \% & 100 \% & 100 \% & 99 \% & 96 \% & 96 \% \\ \text { DROYA } & 100 \% & 100 \% & 99 \% & 100 \% & 100 \% & 99 \% & 96 \% & 96 \% \\ \text { DROAN } & 99 \% & 99 \% & 97 \% & 99 \% & 99 \% & 100 \% & 97 \% & 97 \% \\ \text { DROPS } & 96 \% & 96 \% & 95 \% & 96 \% & 96 \% & 97 \% & 100 \% & 100 \% \\ \text { DROPE } & 96 \% & 96 \% & 95 \% & 96 \% & 96 \% & 97 \% & 100 \% & 100 \%\end{array}$

D BigH1 fehérjeszekvenciák összehasonlítása különböző Drosophila fajokban

DROME DROSI DROSE DROER DROYA DROAN DROPS DROPE

\begin{tabular}{rrrrrrrrr} 
DROME & $100 \%$ & $92 \%$ & $92 \%$ & $83 \%$ & $84 \%$ & $56 \%$ & $31 \%$ & $39 \%$ \\
DROSI & $92 \%$ & $100 \%$ & $97 \%$ & $82 \%$ & $84 \%$ & $55 \%$ & $32 \%$ & $39 \%$ \\
DROSE & $92 \%$ & $97 \%$ & $100 \%$ & $82 \%$ & $83 \%$ & $56 \%$ & $32 \%$ & $39 \%$ \\
DROER & $83 \%$ & $82 \%$ & $82 \%$ & $100 \%$ & $85 \%$ & $55 \%$ & $28 \%$ & $35 \%$ \\
DROYA & $84 \%$ & $84 \%$ & $83 \%$ & $85 \%$ & $100 \%$ & $56 \%$ & $29 \%$ & $37 \%$ \\
DROAN & $56 \%$ & $55 \%$ & $56 \%$ & $55 \%$ & $56 \%$ & $100 \%$ & $29 \%$ & $36 \%$ \\
DROPS & $31 \%$ & $32 \%$ & $32 \%$ & $28 \%$ & $29 \%$ & $29 \%$ & $100 \%$ & $92 \%$ \\
\hline DROPE & $39 \%$ & $39 \%$ & $39 \%$ & $35 \%$ & $37 \%$ & $36 \%$ & $92 \%$ & $100 \%$
\end{tabular}

E BigH1 globuláris doménszekvenciák összehasonlítása különböző Drosophila fajokban

DROME DROSI DROSE DROER DROYA DROAN DROPS DROPE

$\begin{array}{rrrrrrrrr}\text { DROME } & 100 \% & 99 \% & 96 \% & 96 \% & 95 \% & 56 \% & 47 \% & 47 \% \\ \text { DROSI } & 99 \% & 100 \% & 97 \% & 97 \% & 95 \% & 55 \% & 47 \% & 47 \% \\ \text { DROSE } & 96 \% & 97 \% & 100 \% & 95 \% & 92 \% & 55 \% & 48 \% & 48 \% \\ \text { DROER } & 96 \% & 97 \% & 95 \% & 100 \% & 95 \% & 55 \% & 45 \% & 45 \% \\ \text { DROYA } & 95 \% & 95 \% & 92 \% & 95 \% & 100 \% & 51 \% & 44 \% & 44 \% \\ \text { DROAN } & 56 \% & 55 \% & 55 \% & 55 \% & 51 \% & 100 \% & 52 \% & 52 \% \\ \text { DROPS } & 47 \% & 47 \% & 48 \% & 45 \% & 44 \% & 52 \% & 100 \% & 100 \% \\ \text { DROPE } & 47 \% & 47 \% & 48 \% & 45 \% & 44 \% & 52 \% & 100 \% & 100 \%\end{array}$

26. ábra. A BigH1 fehérje fajok között kisebb hasonlóságot mutat, mint a H1. A) H1 és BigH1 fehérjék globuláris doménjének szerkezete, a konzerváltság mértékének feltüntetésével (0-100\%). B) A teljes hosszúságú $\mathrm{H} 1$ fehérjeszekvenciák, C) a $\mathrm{H} 1$ globuláris doménszekvenciák, D) a teljes hosszúságú BigH1 fehérje E) és a BigH1 globuláris doménszekvenciák hasonlósága Drosophila fajok között, szekvencia illesztés alapján (távolsági mátrix). A mátrix átlót (teljes egyezés) sárga szín jelöli. A fajnevek rövidítéseit a 4. táblázat tartalmazza. 


\section{EREDMÉNYEK MEGVITATÁSA}

A korai embrionális stádium a gerinces és a gerinctelen élőlényekben egyaránt a fejlődés legkritikusabb szakasza, hiszen ekkor alakul ki anyai géntermékek hatására a későbbi fejlődési stádiumok zavartalan lezajlásához szükséges kromatinszerkezet és génexpressziós program, amely lehetővé teszi az egyed önálló fejlődését. A korai embriógenezist jellemző kromatinszerkezetnek rendszerint alkotóeleme egy alternatív linker hiszton fehérje, amelyet kifejeződési mintázatának megfelelően ivarvonal - és embrióspecifikus linker hisztonnak nevezünk.

A Drosophila melanogaster hím és nőstény ivarvonalában, illetve a korai embrionális fejlődés során a BigH1 alternatív hiszton van jelen, amely más ivarvonal- és embrióspecifikus linker hisztonokhoz hasonlóan a maternális-zigótikus tranzíció folyamán fokozatosan a kanonikus linker hiszton $\mathrm{H} 1$ fehérjére cserélődik. A BigH1 embriógenezisben betöltött pontos szerepe, illetve az, hogy miért alkalmasabb a linker hiszton funkció betöltésére ebben a fejlődési stádiumban, mint a kanonikus $\mathrm{H} 1$, mindeddig ismeretlen volt.

Tizenkét Drosophila fajban érhető el BigH1 és $\mathrm{H} 1$ fehérjeszekvencia, mely alapján megállapítható, hogy a BigH1 kevésbé konzervált linker hiszton, mint a szomatikus H1. Azonban közeli rokon fajok között a BigH1 esetén is nagymértékü a hasonlóság, különösen a globuláris doménben, míg a törzsfán egymástól távolabbi fajokat tekintve a hasonlóság kevesebb, mint $30 \%$ is lehet. A teljes hosszúságú BigH1 és $\mathrm{H} 1$ fehérjék szekvencia illesztéssel történő összehasonlítása alapján a két linker hiszton szintén csekély, 30\% alatti hasonlóságot mutat. $\mathrm{A}$ kismértékű hasonlóság ellenére a BigH1 fehérje is teljes mértékben alkalmas a linker hiszton funkció ellátására a korai embriógenezis alatt.

A BigH1 alternatív linker hiszton fehérje fejlődésben betöltött szerepének feltérképezéséhez olyan transzgenikus Drosophila vonalakat alkalmaztunk, amelyekben a BigH1 fehérje részben vagy teljes mértékben a kanonikus $\mathrm{H} 1$ fehérjére lett lecserélve. Az ily módon létrehozott állatok vizsgálatával kimutattuk, hogy a kanonikus $\mathrm{H} 1$ fehérje normál laboratóriumi körülmények között $\left(25{ }^{\circ} \mathrm{C}\right)$ alkalmas a BigH1 szerepének átvételére, hiszen a BigH1-H1 kiméra fehérjét, illetve 
a BigH1 helyett H1-et hordozó állatok rendellenességek nélkül fejlődnek, és a vad típushoz hasonló túlélést mutatnak. Ezen eredményeinket alátámasztják az irodalomban megjelent kutatások is, miszerint a BigH1 hiányát a korai embrionális fejlődés során a szomatikus H1 fehérje kompenzálja $(58,59)$.

Azokban a mutánsokban, melyekben a BigH1 C-terminális vagy centrális globuláris doménjét (H1-CTD és H1-GD mutánsok) a $\mathrm{H} 1$ fehérje ezeknek megfeleltethető doménjeire cseréltük, olyan szubletális korai embrionális fenotípusokat figyeltünk meg, mint a mag elimináció. Ezekben az állatokban az embrió kortikális régiójából nagyobb mennyiségü mag süllyed le a vad típushoz mérten. A lesüllyedő magok gamma-H2Av pozitívak, amely arra utal, hogy a fenotípust nagymértékü DNS-károsodás okozza. A megjelenő fenotípusok okaként kizárható az, hogy a $H H H$ mutánsban alacsonyabb a kiméra fehérje mennyisége, hiszen a szintén $\mathrm{N}$-terminális mutáns (H1-NTD) HBB embriókban hasonlóan alacsony kiméra fehérje mennyiség tapasztalható, azonban az állatok fenotípusa a vad típushoz mérhető. Fokozott mag eliminációt a NULL és NSTOP mutánsok esetén is tapasztaltunk. Ennek oka az, hogy a BigH1 fehérje hiánya eddig ismeretlen módon a maternális kanonikus $\mathrm{H} 1$ által kompenzált (58), így a megjelenő fenotípus hasonló mértékủ a $H H H$ mutánsban tapasztalttal, melyek esetén a korai embrióban szintén a $\mathrm{H} 1$ az egyetlen linker hiszton. A P0 mutánsban megfigyelt mag eliminációs fenotípusból arra következtetek, hogy nem csupán a BigH1 fehérje jelenléte és doménösszetétele, de a foszforilációs állapota is szerepet játszik a megfelelő fejlődés biztosításához szükséges kromatinszerkezet kialakításában.

Annak ellenére, hogy gyakoribbak a mitótikus hibák a vad típusú BigH1 hiányában, normál laboratóriumi körülmények között a fejlődési program robusztussága képes ezt kompenzálni. Alacsonyabb, az optimálistól eltérő hőmérsékleten azonban az embriógenezis nem tud végbe menni abban az esetben, ha a kanonikus $\mathrm{H} 1$ az egyetlen linker hiszton. A BigH1-H1 kimérák kikelési aránya alacsony hőmérsékleten szintén arra utal, hogy a BigH1 C-terminálisa és globuláris doménje kiemelt fontosságúak a funkció tekintetében, hiszen a H1-GD és H1-CTD kimérák már a fejlődés korai stádiumában nagymértékű letalitást és súlyos osztódási rendellenességeket mutatnak. 
A két linker hiszton fehérje mobilitását vizsgálva azt tapasztaltuk, hogy azokban az embriókban, amelyekben a BigH1 fehérjét $\mathrm{H} 1$ helyettesíti $(H H H)$, a fluoreszcens H2Av-GFP jel visszatérése fakítás után lassabb az S-fázis korai szakaszában, amikor a nukleoszóma kicserélődés és a DNS replikáció folyamata a legintenzívebb. Ez arra utal, hogy a $\mathrm{H} 1$ linker hiszton kevésbé mobilis, mint a BigH1, és ezáltal lassabb nukleoszóma össze- és szétszerelődést tesz lehetővé. Ezt támogatja az a megfigyelésünk is, hogy a $H H H$ embriókban nagyobb mennyiségü H2Av fehérjét tartalmazó lipidcsepp található a magok körül, mint a vad típusú embriók esetén. Feltételezésünk szerint a $H H H$ embriókban e lipidcseppek a kevésbé dinamikus nukleoszóma kicserélődés következményeként felhalmozódnak a citoplazmában.

A linker hiszton típusa nem csupán a nukleoszómák dinamikáját, de érdekes módon azok stabilitását is meghatározza. Azok a nukleoszómák, amelyek $\mathrm{H} 1$ jelenlétében jöttek létre, kevésbé stabilak sókezeléssel szemben, mint a BigH1 jelenlétében kialakulók, hiszen a H2Av, H3 és H4 core hiszton fehérjék alacsonyabb sókoncentráció mellett távoztak a $\mathrm{HHH}$ embriókból izolált kromatinról. Ezzel szemben azonban a $\mathrm{H} 1$ hiszton magasabb sókoncentrációval távolítható el a kromatinról, mint a BigH1, vagyis a H1-et tartalmazó kromatoszómák stabilabbak.

Az a látszólagos ellentmondás, hogy BigH1 jelenlétében a nukleoszómák dinamikusabban képesek kicserélődni az S-fázis során, ugyanakkor rezisztensebbek sókezeléssel szemben, azaz stabilabbak, feloldható a következő hipotézissel (27. ábra). A BigH1 linker hiszton lazábban kapcsolódik a nukleoszómákhoz, így a hiszton oktamer könnyebben „elcsúszik” a DNS-en, megtalálva az energetikailag legkedvezőbb pozíciókat, ami stabilabb nukleoszómaDNS kölcsönhatást eredményez. Ezekröl a nukleoszómákról a BigH1 könnyen eltávolítható. A H1 ezzel szemben erősebb kapcsolatot létesít a nukleoszómákkal, így azok energetikailag kevésbé kedvező pozíciókba kényszerülnek. Azonban ha megfelelő szabályozó faktorok jelen vannak, akkor ez a nukleoszóma elrendezés a génexpresziós program működését támogathatja. A hipotézist megerősíti a H1-CTD és H1-GD mutánsoknál tapasztalt kondícionális letális fenotípus, hiszen a $\mathrm{H} 1$ erősebb nukleoszóma-kötő képességéért minden bizonnyal a globuláris és Cterminális domének felelősek, melyek a linker hisztonok esetén bizonyítottan részt vesznek a nukleoszómához kapcsolódásban (17-20). A H1 fehérje szorosabb 
kapcsolata a nukleoszómákkal a FRAP kísérleteknél tapasztalt csökkent mobilitásban is megnyilvánul, hiszen a nukleoszómákhoz erősebben kapcsolódó H1 hiszton kevésbé támogatja a rendkívül dinamikus nukleoszóma össze- és szétszerelődést a replikáció során, amely ahhoz szükséges, hogy a korai embrióban lejátszódhassanak a gyors, egymást követő osztódások. Ez mitótikus hibákban nyilvánul meg, amelyek hátterében a replikáció rendellenes müködése állhat, melyre a DNS-károsodást jelző markerre pozitív besüllyedő magok nagy mennyisége utal a $H H H$ mutáns embriókban. Ezt támogatja továbbá, hogy míg vad típusú embriókban a néhány lesüllyedő mag PCNA negatív, addig a $\mathrm{HHH}$ mutánsban az eliminált magok PCNA festődést mutatnak, azt sugallva, hogy ezek a magok kiesnek az osztódási szikronból és lemaradnak a replikáció folyamatában, ami valószínúleg a DNS-károsodás és az elimináció oka. Ezek a fenotípusok alacsony hőmérsékleten jóval kifejezettebbek, melynek oka feltételezésünk szerint az, hogy ilyen körülmények között a $\mathrm{H} 1$ jelenléte lényegébe „befagyasztja” a nukleoszómákat energetikailag kedvezőtlen pozíciókba, ami ellehetetleníti a replikáció megfelelő lejátszódását. A BigH1 és $\mathrm{H} 1$ fehérjék modellezése mindezt alátámasztja, ugyanis míg a $\mathrm{H} 1$ hiszton globuláris doménjében megtalálható egy hurok (L3), amelyet az irodalomban leírtak, mint DNS kötésben szerepet játszó régiót (24), addig a BigH1 alternatív hiszton esetén ez a hurok megrövidül, így feltételezhető, hogy kapcsolata a DNS-sel gyengébb. Tizenkét Drosophila faj BigH1 fehérjeszekvenciájának összehasonlitása azt mutatja, hogy a DNS-kötő hurok megrövidülése általános a fajok között. 


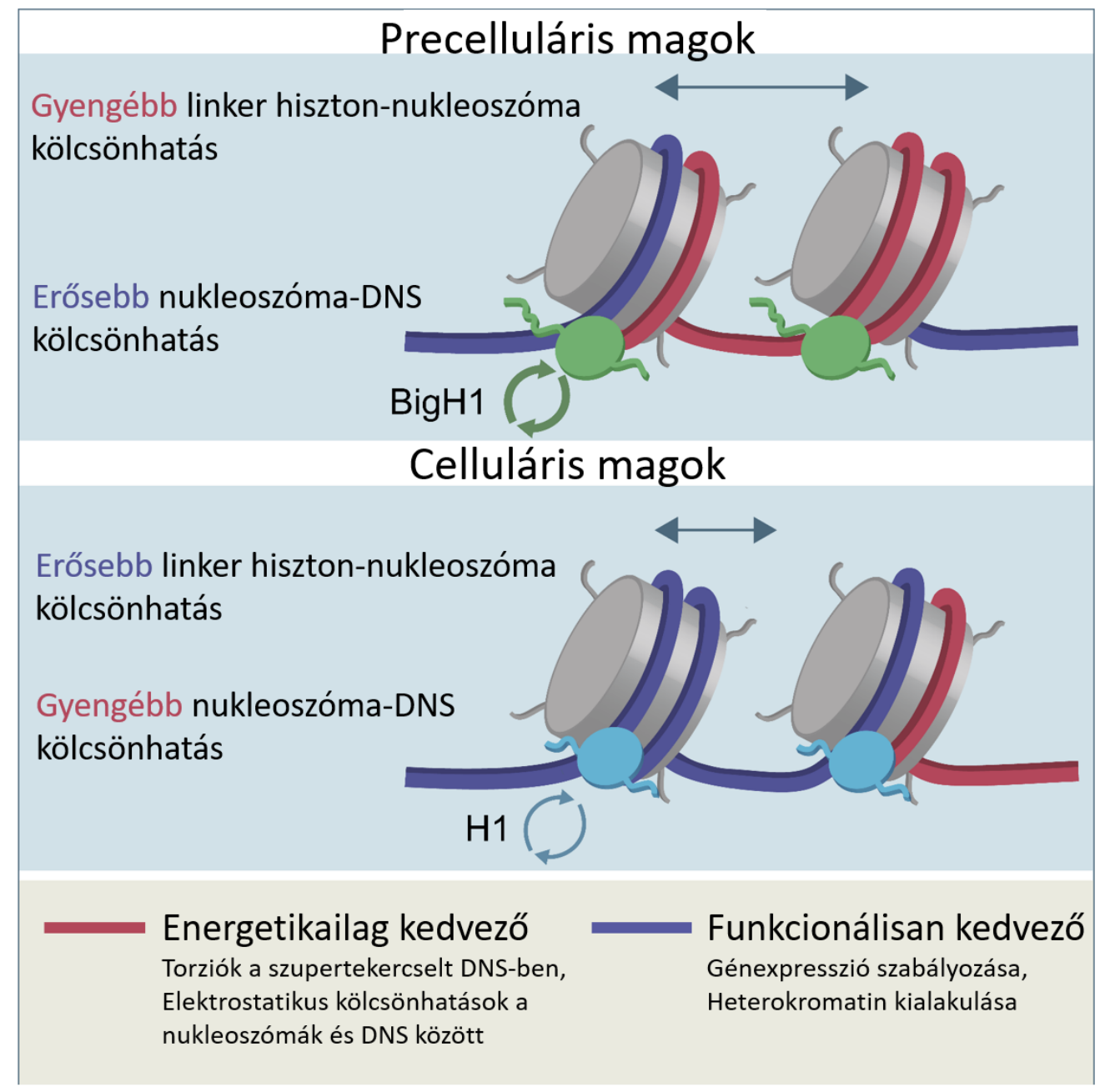

27. ábra. A BigH1 linker hiszton gyengébben kapcsolódik a nukleoszómákhoz, mint a szomatikus H1, ami lehetővé teszi a nukleoszómák szabadabb elmozdulását energetikailag kedvezőbb pozíciókba, így a BigH1 jelenlétében kialakult nukleoszómák stabilabbak. A H1 linker hiszton szorosabb kapcsolata a nukleoszómákkal funkcionálisan kedvező lehet, és a génexpressziós program szempontjából előnyös.

A két linker hiszton fehérje DNS-kötő hurokban való különbsége alternatív nukleoszóma kötést eredményezhet. A vad típusú embriókban tapasztalt, $H H H$ mutánshoz képest megnövekedett nukleoszómális DNS-hossz azt sugallja, hogy a BigH1 fehérje nagyobb területet fed le, amelynek egyik oka az lehet, hogy pusztán a méretéből eredően a nagyobb térkitöltése kiterjedtebben védi meg a kromatint az MNáz emésztéssel szemben. Nem zárható ki az sem, hogy a BigH1 mind a nukleoszómába belépő, mind pedig a kilépő DNS-hez kapcsolódik, szemben a kanonikus $\mathrm{H} 1$ fehérjével, amelyröl ismert, hogy úgynevezett off-dyad módon kötődik 
a nukleoszómához, vagyis a nukleoszóma kettős tengelyének közelében kapcsolódik a nukleszómális DNS-hez és az egyik oldali linker DNS-hez (24). Az eltérö kötési mód hozzájárulhat ahhoz, hogy a BigH1-et hordozó nukleoszómákban található DNS néhány bázispárral hosszabb.

Kimutattam továbbá, hogy $\mathrm{H} 1$ jelenlétében megváltozik bizonyos ivarvonalspecifikus és intermedier transzpozonok RNS mennyisége, némelyek csökkennek, mások jelentősen megnövekednek. Az expressziós méréseket felnőtt állatok petefészkén végeztem, ahol a BigH1 fehérje szintén jelen van, azonban csak bizonyos sejttípusokban. Annak ellenére, hogy heterogén szövetet vizsgáltam, melyekben ivarvonal- és szomatikus sejtek is jelen vannak, a BigH1 H1-re történő cseréje szignifikáns változásokat eredményezett a transzpozonok kifejeződésében. Ez magyarázható a hipotézisünkkel, miszerint a $\mathrm{BigH} 1$ vagy $\mathrm{H} 1$ jelenlétében kialakult nukleoszómák pozíciója nem feltétlen azonos, ami befolyásolhatja a transzpozonok, illetve akár fehérjekódoló gének kifejeződését is. Ezen hipotézisünket a jövőben vad típusú és $H H H$ mutáns embriókból és petefészkekből származó RNS minták újgenerációs szekvenálásával tervezzük bizonyítani.

A dolgozatomban bemutatott eredmények alátámasztják, hogy az ivarvonalés embrióspecifikus BigH1 linker hiszton az embrionális fejlődés kezdetén lehetővé teszi a gyors replikációhoz és magosztódásokhoz szükséges dinamikus nukleoszóma össze- és szétszerelődést. 


\section{KÖSZÖNETNYILVÁNÍTÁS}

Hálás köszönettel tartozom témavezetömnek, Dr. Boros Imrének, hogy a kutatócsoportjában végezhettem a doktori dolgozatomban bemutatott kísérleteket, továbbá Dr. Henn Lászlónak, hogy csatlakozhattam a témájához, illetve mindkettőjüknek köszönöm a munkámhoz nyújtott javaslataikat, szakmai támogatásukat és iránymutatásukat. Köszönettel tartozom Ökrösné Katalinnak, aki példátlan szakmai tapasztalatával és jó tanácsaival az évek alatt rengeteg segítséget nyújtott a munkámhoz. Köszönöm minden kedves szerzőtársnak, akik munkájukkal hozzájárultak a dolgozat alapját képező publikációhoz. Köszönöm Dr. Vilmos Péternek és Dr. habil. Pankotai Tibornak, hogy a dolgozatom bírálatát vállalták és hasznos tanácsokat nyújtottak a jobbá tételéhez. Köszönöm továbbá a családomnak és páromnak, Dr. Vedelek Balázsnak, hogy támogattak a munkám során.

Ez a munka az OTKA-116372, GINOP-2.3.2-15-2016-00032, GINOP-2.3.215-2016-00020 és GINOP-2.3.2-15-2016-00001 pályázatok támogatásával valósult meg. 


\section{IRODALOMJEGYZÉK}

1. Luger K, Mäder AW, Richmond RK, Sargent DF, Richmond TJ. Crystal structure of the nucleosome core particle at 2.8 A resolution. Nature. 1997;

2. Woodcock CL, Ghosh RP. Chromatin higher-order structure and dynamics. Cold Spring Harbor perspectives in biology. 2010.

3. Fyodorov D V., Zhou BR, Skoultchi AI, Bai Y. Emerging roles of linker histones in regulating chromatin structure and function. Nature Reviews Molecular Cell Biology. 2018.

4. ALLFREY VG, FAULKNER R, MIRSKY AE. ACETYLATION AND METHYLATION OF HISTONES AND THEIR POSSIBLE ROLE IN THE REGULATION OF RNA SYNTHESIS. Proc Natl Acad Sci USA. 1964;

5. Bannister AJ, Kouzarides T. Regulation of chromatin by histone modifications. Cell Research. 2011.

6. Bhaumik SR, Smith E, Shilatifard A. Covalent modifications of histones during development and disease pathogenesis. Nature Structural and Molecular Biology. 2007.

7. Heintz N, Sive HL, Roeder RG. Regulation of human histone gene expression: kinetics of accumulation and changes in the rate of synthesis and in the half-lives of individual histone mRNAs during the HeLa cell cycle. Mol Cell Biol. 1983;

8. Marzluff WF, Wagner EJ, Duronio RJ. Metabolism and regulation of canonical histone mRNAs: Life without a poly $(A)$ tail. Nature Reviews Genetics. 2008.

9. Marzluff WF, Gongidi P, Woods KR, Jin J, Maltais LJ. The human and mouse replication-dependent histone genes. Genomics. 2002;

10. Lifton RP, Goldberg ML, Karp RW, Hogness DS. The organization of the histone genes in Drosophila melanogaster: Functional and evolutionary implications. Cold Spring Harb Symp Quant Biol. 1977;

11. Loyola A, Almouzni G. Marking histone H3 variants: How, when and why? Trends in Biochemical Sciences. 2007.

12. Millar $\mathrm{CB}$. Organizing the genome with $\mathrm{H} 2 \mathrm{~A}$ histone variants. Biochemical Journal. 2013.

13. Mattiroli F, D'Arcy S, Luger K. The right place at the right time: chaperoning core histone variants. EMBO Rep. 2015;

14. FlyBase [Internet]. Available from: http://flybase.org/

15. Hergeth SP, Schneider R. The $\mathrm{H} 1$ linker histones: multifunctional proteins beyond the nucleosomal core particle. EMBO Rep. 2015;

16. Sarg B, Lopez R, Lindner H, Ponte I, Suau P, Roque A. Sequence conservation of linker histones between chicken and mammalian species. 
Data Br. 2014;

17. Allan J, Hartman PG, Crane-robinson C, Aviles FX. The structure of histone $\mathrm{H} 1$ and its location in chromatin. Nature. 1980;

18. Simpson RT. Structure of the Chromatosome, a Chromatin Particle Containing 160 Base Pairs of DNA and All the Histones. Biochemistry. 1978;

19. Schiessel H. How short-ranged electrostatics controls the chromatin structure on much larger scales. Europhys Lett. 2002;

20. Allan J, Mitchell T, Harborne N, Bohm L, Crane-Robinson C. Roles of H1 domains in determining higher order chromatin structure and $\mathrm{H} 1$ location. $J$ Mol Biol. 1986;

21. Roque A, lloro I, Ponte I, Arrondo JLR, Suau P. DNA-induced secondary structure of the carboxyl-terminal domain of histone H1. J Biol Chem. 2005;

22. öberg $\mathrm{C}$, Belikov $\mathrm{S}$. The $\mathrm{N}$-terminal domain determines the affinity and specificity of $\mathrm{H} 1$ binding to chromatin. Biochem Biophys Res Commun. 2012;

23. Vila R, Ponte I, Collado M, Arrondo JLR, Jiménez MA, Rico M, et al. DNAinduced $\alpha$-Helical Structure in the $\mathrm{NH} 2$-terminal Domain of Histone H1. J Biol Chem. 2001;

24. Zhou BR, Jiang J, Feng H, Ghirlando R, Xiao TS, Bai Y. Structural Mechanisms of Nucleosome Recognition by Linker Histones. Mol Cell. 2015;

25. Zhou BR, Feng H, Kato H, Dai L, Yang Y, Zhou Y, et al. Structural insights into the histone H1-nucleosome complex. Proc Natl Acad Sci U S A. 2013;

26. Herrera JE, West KL, Schiltz RL, Nakatani Y, Bustin M. Histone H1 Is a Specific Repressor of Core Histone Acetylation in Chromatin. Mol Cell Biol. 2000;

27. Brownell JE, Allis CD. Special HATs for special occasions: Linking histone acetylation to chromatin assembly and gene activation. Curr Opin Genet Dev. 1996;

28. Ura K, Kurumizaka H, Dimitrov S, Almouzni G, Wolffe AP. Histone acetylation: Influence on transcription, nucleosome mobility and positioning, and linker histone-dependent transcriptional repression. EMBO J. 1997;

29. Bresnick EH, Bustin M, Marsaud V, Richard-foy H, Hager GL. The transcriptionally-active MMTV promoter is depleted of histone H1. Nucleic Acids Res. 1992;

30. Sun J, Wei HM, Xu J, Chang JF, Yang Z, Ren X, et al. Histone H1-mediated epigenetic regulation controls germline stem cell self-renewal by modulating H4K16 acetylation. Nat Commun. 2015;

31. Yang SM, Kim BJ, Toro LN, Skoultchi AI. H1 linker histone promotes epigenetic silencing by regulating both DNA methylation and histone $\mathrm{H} 3$ methylation. Proc Natl Acad Sci U S A. 2013;

32. Lu X, Wontakal SN, Emelyanov A V., Morcillo P, Konev AY, Fyodorov D V., 
et al. Linker histone $\mathrm{H} 1$ is essential for Drosophila development, the establishment of pericentric heterochromatin, and a normal polytene chromosome structure. Genes Dev. 2009;

33. Vujatovic O, Zaragoza K, Vaquero A, Reina O, Bernués J, Azorín F. Drosophila melanogaster linker histone $\mathrm{dH} 1$ is required for transposon silencing and to preserve genome integrity. Nucleic Acids Res. 2012;

34. Lu X, Wontakal SN, Kavi H, Kim BJ, Guzzardo PM, Emelyanov A V., et al. Drosophila $\mathrm{H} 1$ regulates the genetic activity of heterochromatin by recruitment of Su(var)3-9. Science (80- ). 2013;

35. Iwasaki YW, Murano K, Ishizu H, Shibuya A, Iyoda Y, Siomi MC, et al. Piwi Modulates Chromatin Accessibility by Regulating Multiple Factors Including Histone H1 to Repress Transposons. Mol Cell. 2016;

36. Th'ng JPH, Sung R, Ye M, Hendzel MJ. H1 family histones in the nucleus: Control of binding and localization by the C-terminal domain. J Biol Chem. 2005;

37. Terme JM, Sesé B, Millán-Ariño L, Mayor R, Belmonte JCI, Barrero MJ, et al. Histone $\mathrm{H} 1$ variants are differentially expressed and incorporated into chromatin during differentiation and reprogramming to pluripotency. J Biol Chem. 2011;

38. Fan Y, Sirotkin A, Russell RG, Ayala J, Skoultchi Al. Individual Somatic H1 Subtypes Are Dispensable for Mouse Development Even in Mice Lacking the H10Replacement Subtype. Mol Cell Biol. 2001;

39. Fan Y, Nikitina T, Zhao J, Fleury TJ, Bhattacharyya R, Bouhassira EE, et al. Histone $\mathrm{H} 1$ depletion in mammals alters global chromatin structure but causes specific changes in gene regulation. Cell. 2005;

40. Ramón A, Muro-Pastor MI, Scazzocchio C, Gonzalez R. Deletion of the unique gene encoding a typical histone $\mathrm{H} 1$ has no apparent phenotype in Aspergillus nidulans. Mol Microbiol. 2000;

41. Patterton HG, Landel CC, Landsman D, Peterson CL, Simpson RT. The biochemical and phenotypic characterization of Hho1p, the putative linker histone H1 of Saccharomyces cerevisiae. J Biol Chem. 1998;

42. Green GR, Poccia DL. Phosphorylation of sea urchin sperm H1 and H2B histones precedes chromatin decondensation and $\mathrm{H} 1$ exchange during pronuclear formation. Dev Biol. 1985;

43. Brandt WF, Schwager SUL, Rodrigues JA, Busslinger M. Isolation and amino acid sequence analysis reveal an ancient evolutionary origin of the cleavage stage (CS) histones of the sea urchin. Eur J Biochem. 1997;

44. Green GR, Collas P, Burrell A, Poccia DL. Histone phosphorylation during sea urchin development. Semin Cell Dev Biol. 1995;

45. Smith RC, Dworkin-Rastl E, Dworkin MB. Expression of a histone H1-like protein is restricted to early Xenopus development. Genes Dev. 1988;

46. Dworkin-Rastl E, Kandolf $\mathrm{H}$, Smith RC. The maternal histone $\mathrm{H} 1$ variant, 
$\mathrm{H} 1 \mathrm{M}$ (B4 protein), is the predominant $\mathrm{H} 1$ histone in Xenopus pregastrula embryos. Dev Biol. 1994;

47. Müller K, Thisse C, Thisse B, Raz E. Expression of a linker histone-like gene in the primordial germ cells in zebrafish. Mech Dev. 2002;

48. Wibrand $\mathrm{K}$, Olsen LC. Linker histone H1M transcripts mark the developing germ line in zebrafish. Mech Dev. 2002;

49. Maeda C, Sato S, Hattori N, Tanaka S, Yagi S, Shiota K. DNA hypomethylation circuit of the mouse oocyte-specific histone $\mathrm{H} 1$ foo gene in female germ cell lineage. Biol Reprod. 2008;

50. Funaya S, Ooga M, Suzuki MG, Aoki F. Linker histone H1FOO regulates the chromatin structure in mouse zygotes. FEBS Lett. 2018;

51. Pérez-Montero S, Carbonell A, Morán T, Vaquero A, Azorín F. The embryonic linker histone $\mathrm{H} 1$ variant of Drosophila, $\mathrm{dBigH} 1$, regulates zygotic genome activation. Dev Cell. 2013;

52. Blumenthal $A B$, Kriegstein HJ, Hogness DS. The units of DNA replication in Drosophila melanogaster chromosomes. Cold Spring Harb Symp Quant Biol. 1974;

53. Foe VE, Alberts BM. Studies of nuclear and cytoplasmic behavior during the five mitotic cycles that precede gastrulation in Drosophila embryogenesis. J Cell Sci. 1983;

54. Farrell JA, O'Farrell PH. From egg to gastrula: How the cell cycle is remodeled during the drosophila mid-blastula transition. Annu Rev Genet. 2014;

55. Harrison MM, Eisen MB. Transcriptional Activation of the Zygotic Genome in Drosophila. In: Current Topics in Developmental Biology. 2015.

56. Nakamura A, Shirae-Kurabayashi M, Hanyu-Nakamura K. Repression of early zygotic transcription in the germline. Current Opinion in Cell Biology. 2010.

57. Carbonell A, Pérez-Montero S, Climent-Cantó P, Reina O, Azorín F. The Germline Linker Histone $\mathrm{dBigH} 1$ and the Translational Regulator Bam Form a Repressor Loop Essential for Male Germ Stem Cell Differentiation. Cell Rep. 2017;

58. Li KK, Han D, Chen F, Li R, Zhou B-R, Bai Y, et al. Compensatory replacement of the $\mathrm{BigH} 1$ variant histone by canonical $\mathrm{H} 1$ supports normal embryonic development in Drosophila. bioRxiv. 2019 Jan 1;789735.

59. Carbonell A, Henn L, Pérez-Roldán J, Tamirisa S, Szabó A, Boros IM, et al. In response to $\mathrm{Li}$ et al.: Linker histones function in Drosophila embryogenesis. bioRxiv. 2020 Mar. doi:

https://doi.org/10.1101/2020.03.21.001529

60. Jeong JY, Yim HS, Ryu JY, Lee HS, Lee JH, Seen DS, et al. One-step sequence-and ligation-independent cloning as a rapid and versatile cloning method for functional genomics Studies. Appl Environ Microbiol. 2012; 
61. Bo Zhai JV, Beausoleil SA, Mintseris J, Gygi SP. Phosphoproteome analysis of drosophila melanogaster embryos. J Proteome Res. 2008;

62. Henn L, Szabó A, Imre L, Román Á, Ábrahám A, Vedelek B, et al. Alternative linker histone permits fast paced nuclear divisions in early Drosophila embryo. Nucleic Acids Res. 2020;

63. Schägger H, von Jagow G. Tricine-sodium dodecyl sulfate-polyacrylamide gel electrophoresis for the separation of proteins in the range from 1 to 100 kDa. Anal Biochem. 1987;

64. Abràmoff MD, Magalhães PJ, Ram SJ. Image processing with imageJ. Biophotonics International. 2004.

65. Imre L, Simándi Z, Horváth A, Fenyofalvi G, Nánási $P$, Niaki EF, et al. Nucleosome stability measured in situ by automated quantitative imaging. Sci Rep. 2017;

66. Czech B, Preall JB, McGinn J, Hannon GJ. A transcriptome-wide RNAi screen in the drosophila ovary reveals factors of the germline piRNA pathway. Mol Cell. 2013;

67. Livak KJ, Schmittgen TD. Analysis of relative gene expression data using real-time quantitative PCR and the 2- $\Delta \Delta C T$ method. Methods. 2001;

68. Šali A, Blundell TL. Comparative protein modelling by satisfaction of spatial restraints. J Mol Biol. 1993;

69. 4QLC Gallus H5 linker histone model. RCSB Protein Data Base.

70. Okonechnikov K, Golosova O, Fursov M, Varlamov A, Vaskin Y, Efremov I, et al. Unipro UGENE: A unified bioinformatics toolkit. Bioinformatics. 2012.

71. Gasteiger E, Hoogland C, Gattiker A, Duvaud S, Wilkins MR, Appel RD, et al. Protein Identification and Analysis Tools on the ExPASy Server. In: The Proteomics Protocols Handbook. 2005.

72. SnapGene [Internet]. 2004. Available from: http://snapgene.com

73. GraphPad Prism [Internet]. Available from: http://graphpad.com

74. Blythe SA, Wieschaus EF. Coordinating Cell Cycle Remodeling with Transcriptional Activation at the Drosophila MBT. In: Current Topics in Developmental Biology. 2015.

75. Takada S, Kelkar A, Theurkauf WE. Drosophila checkpoint kinase 2 couples centrosome function and spindle assembly to genomic integrity. Cell. 2003;

76. Madigan JP, Chotkowski HL, Glaser RL. DNA double-strand break-induced phosphorylation of Drosophila histone variant $\mathrm{H} 2 \mathrm{Av}$ helps prevent radiationinduced apoptosis. Nucleic Acids Res. 2002;

77. Kisielewska J, Lu P, Whitaker M. GFP-PCNA as an S-phase marker in embryos during the first and subsequent cell cycles. Biol Cell. 2005;

78. Iwasaki YW, Murano K, Ishizu H, Shibuya A, lyoda Y, Siomi MC, et al. Piwi Modulates Chromatin Accessibility by Regulating Multiple Factors Including 
Histone H1 to Repress Transposons. Mol Cell. 2016;

79. Li XY, Harrison MM, Villalta JE, Kaplan T, Eisen MB. Establishment of regions of genomic activity during the Drosophila maternal to zygotic transition. Elife. 2014;

80. Das C, Hizume K, Batta K, Kumar BRP, Gadad SS, Ganguly S, et al. Transcriptional Coactivator PC4, a Chromatin-Associated Protein, Induces Chromatin Condensation. Mol Cell Biol. 2006;

81. Côté J, Utley RT, Workman JL. Basic Analysis of Transcription Factor Binding to Nucleosomes. Methods Mol Genet. 1995;

82. Li Z, Thiel K, Thul PJ, Beller M, Kühnlein RP, Welte MA. Lipid droplets control the maternal histone supply of Drosophila embryos. Curr Biol. 2012; 


\section{8. ÖSSZEFOGLALÁS}

A magasabb rendű kromatinszerveződés kialakitásában és a kromatin hozzáférhetősége által a génexpresszió szabályozásában kiemelt szerepet játszanak a linker hiszton $\mathrm{H} 1$ fehérjék. A többsejtủ élőlények jelentős részénél több linker hiszton variáns is megtalálható, melyek szövet- és fejlődési stádiumspecifikus kifejeződési mintázatot mutathatnak, emellett speciális funkciót tölthetnek be. Ugyanakkor funkcionális redundancia is jellemző sok linker hiszton variánsra, ami megnehezíti vizsgálatukat, hiszen egy variáns deléciója nem minden esetben jár abnormális fenotípussal.

A linker hisztonok egy altípusa a petesejtben és a korai embrionális fejlödés alatt kifejeződő petesejt- és embrióspecifikus variánsok, melyeket jellemzően a fejlödés során felváltanak a szomatikus $\mathrm{H} 1$ típusok. Annak érdekében, hogy ezen speciális linker hisztonok funkcióit vizsgáljuk, a Drosophila melanogaster modellorganizmust alkalmaztuk, amely csupán két linker hiszton fehérjével rendelkezik, a kanonikus szomatikus $\mathrm{H} 1$-gyel és az ivarvonal- és embrióspecifikus BigH1-gyel. Munkánk célja elsősorban a két hiszton fehérje funkcionális különbségeinek feltérképezése volt, melyek vizsgálatához olyan Drosophila vonalakat hoztunk létre, melyek BigH1/H1 kimérákat vagy szomatikus $\mathrm{H} 1$ fehérjét expresszálnak a BigH1 linker hiszton kifejeződési mintázatának megfelelöen.

Megállapítottuk, hogy a BigH1 linker hiszton normál laboratóriumi körülmények között $\left(25^{\circ} \mathrm{C}\right)$ nem esszenciális az embrionális fejlödés végbemeneteléhez, hiszen a szomatikus $\mathrm{H} 1$ fehérje teljes mértékben képes helyettesíteni. Azonban a $\mathrm{H} 1$-et hordozó korai embrióknál nagyobb gyakorisággal figyelhető meg a mag elimináció fenotípusa, mely során a nagymértékủ DNSkárosodást szenvedett magok lesüllyednek az embrió belsejébe. Kimutattuk továbbá, hogy a BigH1 helyett H1-et kifejező embriókban a magok nagyobb méretüek, azonban ennek hátterében nem a kromatin hozzáférhetőségének megváltozása áll.

Szuboptimális hőmérsékleten $\left(15^{\circ} \mathrm{C}\right)$ a BigH1 fehérje globuláris és $\mathrm{C}$ terminális doménjei szükségesek a normális embrionális fejlődési program támogatásához, amire a $\mathrm{H} 1$ fehérje nem alkalmas. Méréseink szerint a BigH1 a H1- 
nél mobilisebb linker hiszton, amely lehetővé teszi a korai embrionális fejlődésre jellemző gyors magi osztódások során a dinamikus nukleoszóma-kicserélődést, hiszen a BigH1 a H1-nél gyengébben kapcsolódik a nukleoszómákhoz, és onnan könnyebben eltávolítható. Ennek következményeképpen a kevésbé mobilis $\mathrm{H} 1$ jelenlétében a replikáció lelassul, alacsony hőmérsékleten pedig nem képes végbe menni, így a H1-et hordozó korai embriók súlyos mitótikus hibákat mutatnak. Felfedeztük, hogy a BigH1 fehérjében megrövidül egy hurok, melyet a H1-ben DNSkötőként írtak le. Ez magyarázattal szolgál arra, hogy a BigH1 miért kapcsolódik gyengébben a nukleoszómákhoz, mint a szomatikus H1.

Kimutattuk továbbá, hogy a BigH1 és $\mathrm{H} 1$ fehérjék jelenlétében bizonyos transzpozon RNS-ek mennyisége megváltozik, ami arra enged következtetni, hogy a két linker hiszton eltérő módon befolyásolja a gének kifejeződését. Feltételezzük, hogy ez nem csupán a transzpozonokat kódoló szekvenciákra igaz, azonban ennek vizsgálatához további kísérletek szükségesek. 


\section{SUMMARY}

Linker histone $\mathrm{H} 1$ proteins play important role in facilitating the formation of higher-order chromatin structures, and regulating the accessibility of chromatin and the expression of genes. Most multicellular species possess multiple $\mathrm{H} 1$ variants which can be tissue- and developmental stage-specific, while also fulfilling special functions. However, many linker histone variants are functionally redundant which makes their research difficult, since deletion of one variant may not cause any detectable phenotype.

A subtype of linker histones are the oocyte- and embryo-specific variants which are expressed in the egg and during the early stages of embryogenesis, and are later replaced by their somatic counterparts. In order to investigate the function of these variants, we utilized the Drosophila melanogaster (fruit fly) model organism, as it possesses only two linker histones, the canonical somatic $\mathrm{H} 1$, and the germline- and embryo-specific BigH1. The aim of our work was to uncover the functional differences between these two linker histones. For this purpose, we have created several Drosophila lines which express BigH1-H1 chimeras or somatic $\mathrm{H} 1$ in the expressional pattern of BigH1.

We have discovered that under optimal conditions $\left(25^{\circ} \mathrm{C}\right), \mathrm{BigH} 1$ is not necessary for embryonic development, and somatic $\mathrm{H} 1$ is fully capable of replacing it. However, embryos expressing somatic $\mathrm{H} 1$ instead of $\mathrm{BigH} 1$ exhibit nuclear fallout phenotype with higher frequency, and more nuclei with damaged DNA are eliminated from the cortical layer of the embryo. We have also shown that nuclei are bigger in volume in the $\mathrm{H} 1$-expressing mutant embryos compared to the wild type, however changes in the accessibility of chromatin are not behind this phenotype.

At suboptimal temperature $\left(15^{\circ} \mathrm{C}\right)$, the globular and C-terminal domains of $\mathrm{BigH} 1$ are necessary for proper embryonic development, for which $\mathrm{H} 1$ is not suitable. According to our experiments, $\mathrm{BigH} 1$ is a more mobile linker histone than $\mathrm{H} 1$, and can enable the dynamic nucleosome exchange necessary for the rapid nuclear divisions during early embryonic development, because BigH1 exhibits weaker binding to nucleosomes compared to $\mathrm{H} 1$. As a result, replication slows down in the presence of $\mathrm{H} 1$, and cannot proceed at low temperature. As such, embryos 
containing $\mathrm{H} 1$ in place of $\mathrm{BigH} 1$ show severe mitotic defects. We have found that a loop which has been described as DNA binding in $\mathrm{H} 1$ is shortened in $\mathrm{BigH} 1$. This provides an explanation for why BigH1's binding to nucleosomes is weaker compared to H1's.

We have also discovered that some transposable element RNAs are differentially expressed in the presence of $\mathrm{BigH} 1$ and $\mathrm{H} 1$, which leads us to believe that the two linker histones influence gene expression in different ways. We believe that this affects not only transposon sequences, however, more research is needed on this subject. 


\section{PUBLIKÁCIÓS LISTA}

\section{MTMT azonosító: 10062451}

\section{A dolgozat alapját képező közlemény:}

Henn, László* ; Szabó, Anikó* ; Imre, László ; Román, Ádám ; Ábrahám, Andrea ; Vedelek, Balázs ; Nánási, Péter ; Boros, Imre M. Alternative linker histone permits fast paced nuclear divisions in early Drosophila embryo. NUCLEIC ACIDS RESEARCH 48 : 16 pp. 9007-9018. (2020)

IF: 11,501

*megosztott első szerzők

További közlemények:

Huliák, Ildikó ; Bodai, László ; Czepán, Mátyás ; Kovács, Dávid ; Szabó, Anikó ; Tiszlavicz, László ; Lázár, György ; Rakonczay, Zoltán ; Hegyi, Péter ; Boros, Imre Miklós et al. Genetic, epigenetic and transcriptional comparison of esophagus tumor-associated and adjacent normal myofibroblasts. ONCOLOGY REPORTS 41 : 2 pp. 839-852. , 14 p. (2019)

IF: 3,417

Carbonell A, Henn L, Pérez-Roldán J, Tamirisa S, Szabó A, Boros IM, et al. In response to Li et al.: Linker histones function in Drosophila embryogenesis. BioRxiv: 2020.03.21.001529. DOI: 10.1101/2020.03.21.001529 


\section{NYILATKOZAT}

A dolgozatban bemutatott kísérleteket az Anyagok és módszerekben leírtak szerint én végeztem el, melyek a következők:

- NULL és PO mutáns állatok létrehozásához szükséges plazmidok megtervezése és teljes klónozási folyamata

- Embriók gyűjtése és előkészítése

- Fehérjemennyiségi vizsgálatok Western blottal

- MNáz esszé

- Nukleoszóma stabilitási esszé kísérletes része

- Génexpressziós mérésekhez mintagyűjtés, feldolgozás, qPCR mérések és értékelésük

- Különböző fajokból származó BigH1 és H1 szekvencia adatok beszerzése és illesztése

A kísérletekhez felhasznált $3 F, H H H, H B B, H B H, B H B, B B H$ és NSTOP mutánsokat Dr. Henn László hozta létre, Ökrösné Katalin közremüködésével. Továbbá ő végezte el az Anyagok és módszerekben nem részletezett kísérleteket, melyek a következők:

- Immunfestések

- Embrió kikelési vizsgálat

- Mag-eliminációs fenotípus vizsgálat

- Magtérfogat mérés

- FRAP mérés és lipidcsepp denzitás mérése

A mutánsok létrehozásához szükséges embriók injektálást az SZBK Drosophila Injektáló Szolgálata végezte.

A nukleoszóma stabilitási esszé adataink bioinformatikai elemzését Dr. Imre László és Dr. Nánási Péter végezték (Debreceni Egyetem).

A BigH1 és $\mathrm{H} 1$ fehérjék globuláris doménjének modelljét Dr. Vedelek Balázs készítette.

Dr. Zsindely Nóra segítséget nyújtott a Bioanalyzer Expert szoftver használatában. 


\section{FÜGGELÉK}

\begin{tabular}{|c|c|}
\hline Név & Szekvencia 5'-3 \\
\hline loxP mCh Fw & $\begin{array}{l}\text { TCGTATAGCATACATTATACGAAGTTATTAGTGAGCAAGGG } \\
\text { CGAGGAGGA }\end{array}$ \\
\hline loxP mCh Rev & $\begin{array}{l}\text { ACTTCGTATAATGTATGCTATACGAAGTTATCTTGTACAGCT } \\
\text { CGTCCATGCCG }\end{array}$ \\
\hline loxP 3'UTR & $\begin{array}{l}\text { TTCGTATAGCATACATTATACGAAGTTATAATTATGATTTATA } \\
\text { TGTTTTTTTTTCAGTACATGTG }\end{array}$ \\
\hline loxP 5’UTR & $\begin{array}{l}\text { ACTTCGTATAATGTATGCTATACGAAGTTATCATGTTATTAG } \\
\text { TTGGAAATTAAATTGAACAAAAATTAGAAATACAACTC }\end{array}$ \\
\hline PSLIC_F & $\begin{array}{l}\text { GAGTTGGTAGCTCGAGATCCGGCAAACAAACCACCGCTGG } \\
\text { TAG }\end{array}$ \\
\hline PSLIC_R & $\begin{array}{l}\text { TTGCCGGATCTCGAGCTACCAACTCTTTTTCCGAAGGTAAC } \\
\text { TGGCT }\end{array}$ \\
\hline S287/288A F & $\begin{array}{l}\text { ACAAGCGGATGCGGCCGAGGCGGGAAAGACTAAAAAGTCG } \\
\text { C }\end{array}$ \\
\hline S287/288A r & TCCCGCCTCGGCCGCATCCGCTTGTAGCTTGACTTTGGTT \\
\hline S299A_F & AGTCGCGAAAGGCAATTGGAACTCTGGCTCAGCCCAAGGC \\
\hline S299A_R & AGAGTTCCAATTGCCTTTCGCGACTTTTTAGTCTTTCCCG \\
\hline S331A_F & CACCGGATCTTGCAATAATGGAGGCCCAGGCCACGTCGAC \\
\hline S331A_R & GCCTCCATTATTGCAAGATCCGGTGTGGAGGCTCCCTTTC \\
\hline S331A_C_F & CCTCCACACCGGATCTTGCA \\
\hline S/A_C_R & GCGCATGAACTCCTTGATGACGT \\
\hline aktin $\mathrm{F}$ & AAGTTGCTGCTCTGGTTGTCG \\
\hline aktin $\mathrm{R}$ & GCCACACGCAGCTCATTGTAG \\
\hline $\mathrm{rp} 49 \mathrm{~F}$ & CCGCTTCAAGGGACAGTATCTG \\
\hline rp49 R & ATCTCGCCGCAGTAAACGC \\
\hline Het-A F & CGCGCGGAACCCATCTTCAGA \\
\hline Het-A R & CGCCGCAGTCGTTTGGTGAGT \\
\hline Burdock F & CGGTAAAATCGCTTCATGGT \\
\hline Burdock R & ACGTTGCATTTCCCTGTTTC \\
\hline gypsy $\mathrm{F}$ & GTTCATACCCTTGGTAGTAGC \\
\hline gypsy $R$ & CAACTTACGCATATGTGAGT \\
\hline zam F & ACTTGACCTGGATACACTCACAAC \\
\hline zam R & GAGTATTACGGCGACTAGGGATAC \\
\hline mdg1 $\mathrm{F}$ & AAACTCCAACTCCCAATCCG \\
\hline mdg1 R & AGTGGTCCCTCGCAGTCGTT \\
\hline blood F & AACAATAGAAAGAAGCCACCGAAC \\
\hline blood R & AGTCATGGACTATTGAGGGTGTTG \\
\hline $297 \mathrm{~F}$ & AAAGGGCGCTCATACAAATG \\
\hline $297 \mathrm{R}$ & TGTGCACATAAAATGGTTCG \\
\hline doc F & GGGTGACTATAACGCCAAGC \\
\hline doc $R$ & GCAAAATCGATCAGGTCTGG \\
\hline idefix $\mathrm{F}$ & AACAAAATCGTGGCAGGAAG \\
\hline idefix R & TCCATTTTTCGCGTTTACTG \\
\hline $412 \mathrm{~F}$ & CACCGGTTTGGTCGAAAG \\
\hline $412 \mathrm{R}$ & GGACATGCCTGGTATTTTGG \\
\hline gtwin $\mathrm{F}$ & TTCGCACAAGCGATGATAAG \\
\hline gtwin $\mathrm{R}$ & GATTGTTGTACGGCGACCTT \\
\hline
\end{tabular}




\begin{tabular}{|r|l|}
\hline tabor $\mathrm{F}$ & ACGTTGTTCACGACATTAGCCG \\
\hline tabor $\mathrm{R}$ & GGGTTGGTTCGGATCTGACG \\
\hline HMS-Beagle $\mathrm{F}$ & AATGCCCTTGTCGGACACGA \\
\hline HMS-Beagle $\mathrm{R}$ & TGATGAAACACATTACCAGAACCTTGA \\
\hline accord $\mathrm{F}$ & ACAATCCACCAACAGCAACA \\
\hline accord R & AAAAGCCAAAATGTCGGTTG \\
\hline I-element $\mathrm{F}$ & GACCAAATAAAAATAATACGACTT \\
\hline I-element $R$ & AACTAATTGCTGGCTTGTTATG \\
\hline
\end{tabular}

1. Függelék táblázat. A kísérletekhez felhasznált primerek neve és szekvenciája.

\begin{tabular}{|l|l|l|l|}
\hline \multicolumn{1}{|c|}{ Elsődleges ellenanyagok } & \multicolumn{1}{c|}{ Típusa } & \multicolumn{1}{c|}{ Hígítás } & \multicolumn{1}{c|}{ Forrás } \\
\hline anti-BigH1 & nyúl monoklonális & $1: 600$ & Ferran Azorin (51) \\
\hline anti-FLAG M2 (F1804) & egér monoklonális & $1: 1000,1: 2000$ & Sigma \\
\hline anti-H3 (ab1791) & nyúl poliklonális & $1: 5000$ & Abcam \\
\hline anti-H4 (ab10158) & nyúl poliklonális & $1: 1000$ & Abcam \\
\hline \multicolumn{1}{|c|}{ Másodlagos ellenanyagok } & & & \\
\hline $\begin{array}{l}\text { Goat Anti-Rabbit } \\
\text { Immunoglobulins/HRP }\end{array}$ & kecske poliklonális & $1: 10000$ & Dako \\
\hline $\begin{array}{l}\text { Rabbit Anti-Mouse } \\
\text { Immunoglobulins/HRP }\end{array}$ & nyúl poliklonális & $1: 10000$ & Dako \\
\hline
\end{tabular}

2. Függelék táblázat. Felhasznált elsődleges és másodlagos ellenanyagok.

\begin{tabular}{|c|c|}
\hline BigH1 & Méret (kDa) \\
\hline vad típus & 38,67 \\
\hline $3 F$ & 41,38 \\
\hline$m C h$ & 68,38 \\
\hline$H B B$ & 34,61 \\
\hline$B H B$ & 41,67 \\
\hline$B B H$ & 35,56 \\
\hline$H B H$ & 28,79 \\
\hline$H H H$ & 29,08 \\
\hline$P O$ & 41,38 \\
\hline
\end{tabular}

3. Függelék táblázat. Vad típusú és módosított BigH1 fehérjék mérete. 


\begin{tabular}{|r|r|c|}
\hline \multicolumn{3}{|c|}{ BigH1 } \\
\hline Aminosav & db & $\%$ \\
\hline Lys & 66 & $18,70 \%$ \\
\hline Glu & 40 & $11,30 \%$ \\
\hline Ala & 38 & $10,80 \%$ \\
\hline Ser & 29 & $8,20 \%$ \\
\hline Pro & 25 & $7,10 \%$ \\
\hline Asp & 23 & $6,50 \%$ \\
\hline Leu & 20 & $5,70 \%$ \\
\hline Thr & 18 & $5,10 \%$ \\
\hline Gly & 17 & $4,80 \%$ \\
\hline Val & 17 & $4,80 \%$ \\
\hline Gln & 13 & $3,70 \%$ \\
\hline Arg & 12 & $3,40 \%$ \\
\hline Met & 12 & $3,40 \%$ \\
\hline Asn & 10 & $2,80 \%$ \\
\hline Ile & 7 & $2,00 \%$ \\
\hline His & 2 & $0,60 \%$ \\
\hline Tyr & 2 & $0,60 \%$ \\
\hline Phe & 1 & $0,30 \%$ \\
\hline Trp & 1 & $0,30 \%$ \\
\hline Cys & 0 & $0,00 \%$ \\
\hline Pyl & 0 & $0,00 \%$ \\
\hline Sec & 0 & $0,00 \%$ \\
\hline & & \\
\hline
\end{tabular}

\begin{tabular}{|r|r|r|}
\hline \multicolumn{3}{|c|}{ H1 } \\
\hline Aminosav & db & $\%$ \\
\hline Lys & 68 & $26,60 \%$ \\
\hline Ala & 50 & $19,50 \%$ \\
\hline Ser & 27 & $10,50 \%$ \\
\hline Val & 20 & $7,80 \%$ \\
\hline Thr & 19 & $7,40 \%$ \\
\hline Pro & 14 & $5,50 \%$ \\
\hline Gly & 11 & $4,30 \%$ \\
\hline Ile & 8 & $3,10 \%$ \\
\hline Leu & 8 & $3,10 \%$ \\
\hline Asp & 6 & $2,30 \%$ \\
\hline Gln & 6 & $2,30 \%$ \\
\hline Glu & 6 & $2,30 \%$ \\
\hline Asn & 3 & $1,20 \%$ \\
\hline Tyr & 3 & $1,20 \%$ \\
\hline Met & 2 & $0,80 \%$ \\
\hline Phe & 2 & $0,80 \%$ \\
\hline Arg & 1 & $0,40 \%$ \\
\hline Cys & 1 & $0,40 \%$ \\
\hline His & 1 & $0,40 \%$ \\
\hline Trp & 0 & $0,00 \%$ \\
\hline Pyl & 0 & $0,00 \%$ \\
\hline Sec & 0 & $0,00 \%$ \\
\hline & & \\
\hline
\end{tabular}

4. Függelék táblázat. $D$. melanogaster BigH1 és $\mathrm{H} 1$ fehérjék aminosav-összetétele. 
A

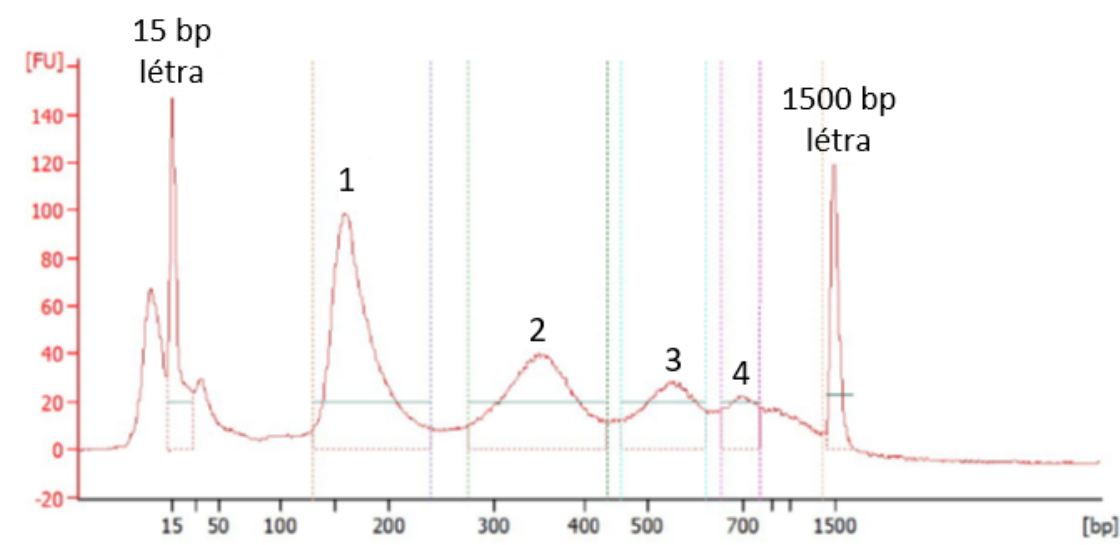

B

\begin{tabular}{|r|r|l|l|l|l|l|r|r|}
$\begin{array}{c}\text { Nukleoszóma } \\
\text { szám }\end{array}$ & \multicolumn{8}{|c|}{ Nukleoszómális DNS hossza (bp) } \\
& \multicolumn{1}{|c|}{ 1. minta } & 2. minta & 3. minta & Átlag & Szórás \\
\hline 1 & 162 & 160 & 160 & 159 & 167 & 167 & 163 & 3,6 \\
\hline 2 & 363 & 354 & 349 & 356 & 363 & 371 & 359 & 7,9 \\
\hline 3 & 559 & 564 & 550 & 554 & 577 & 560 & 561 & 9,4 \\
4 & 746 & 697 & 699 & 699 & 728 & 734 & 717 & 21,4
\end{tabular}

Nukleoszóma szám

1. minta

$\mathrm{HHH}$

\begin{tabular}{|c|c|c|c|c|c|c|c|c|}
\hline \multirow{2}{*}{ Lain } & & & & \\
\hline & 160 & 160 & 158 & 158 & 156 & 156 & 158 & 1,8 \\
\hline 2 & 344 & 348 & 350 & 358 & 344 & 347 & 349 & 5,2 \\
\hline 3 & 552 & 540 & 548 & 550 & 538 & 538 & 544 & 6,4 \\
\hline 4 & 709 & 734 & 692 & 693 & 700 & 684 & 702 & 17,8 \\
\hline
\end{tabular}

C

\begin{tabular}{|c|c|c|c|c|c|c|c|c|}
\hline \multirow{3}{*}{$\begin{array}{c}\text { Nukleoszóma } \\
\text { szám }\end{array}$} & \multicolumn{8}{|c|}{ Mono- és multinukleoszómális DNS aránya (\%) } \\
\hline & \multicolumn{8}{|c|}{ VT } \\
\hline & \multicolumn{2}{|c|}{ 1. minta } & \multicolumn{2}{|c|}{ 2. minta } & \multicolumn{2}{|c|}{ 3. minta } & \multirow{2}{*}{$\begin{array}{l}\text { Átlag } \\
38 \%\end{array}$} & \multirow{2}{*}{$\begin{array}{l}\text { Szórás } \\
7,5 \%\end{array}$} \\
\hline 1 & $35 \%$ & $35 \%$ & $48 \%$ & $47 \%$ & $32 \%$ & $31 \%$ & & \\
\hline 2 & $25 \%$ & $24 \%$ & $25 \%$ & $25 \%$ & $24 \%$ & $24 \%$ & $24 \%$ & $0,5 \%$ \\
\hline 3 & $13 \%$ & $14 \%$ & $11 \%$ & $11 \%$ & $14 \%$ & $14 \%$ & $13 \%$ & $1,4 \%$ \\
\hline 4 & $7 \%$ & $8 \%$ & $5 \%$ & $5 \%$ & $8 \%$ & $8 \%$ & $7 \%$ & $1,6 \%$ \\
\hline ukleoszóma & \multicolumn{8}{|c|}{$\mathrm{HHH}$} \\
\hline & \multicolumn{2}{|c|}{ 1. minta } & \multicolumn{2}{|c|}{ 2. minta } & \multicolumn{2}{|c|}{ 3. minta } & Átlag & Szórás \\
\hline 1 & $37 \%$ & $38 \%$ & $48 \%$ & $46 \%$ & $45 \%$ & $43 \%$ & $43 \%$ & $4,6 \%$ \\
\hline 2 & $25 \%$ & $25 \%$ & $25 \%$ & $25 \%$ & $25 \%$ & $25 \%$ & $25 \%$ & $0,1 \%$ \\
\hline 3 & $13 \%$ & $13 \%$ & $11 \%$ & $12 \%$ & $12 \%$ & $12 \%$ & $12 \%$ & $0,9 \%$ \\
\hline 4 & $7 \%$ & $7 \%$ & $5 \%$ & $5 \%$ & $5 \%$ & $6 \%$ & $6 \%$ & $1,0 \%$ \\
\hline
\end{tabular}

1. Függelék ábra. A) Az MNáz enzimmel emésztett, majd tisztított DNS minták Bioanalyzer DNA 1000 chipen történő futtatásának eredménye (reprezentatív ábra). A számok 1-4-ig a nukleoszóma számot jelentik. B) Három független vad típusú (VT) és HHH mutáns embrióból származó biológiai minta kétszer történő futtatásának eredményeként kapott számadatok a nukleoszómális DNS hosszra vonatkozóan. C) Ugyanezen mintákban a mono- és multinukleoszómális DNS aránya, \%ban megadva. 
A BigH1 N-terminális doménszekvenciák összehasonlítása különbözō Drosophila fajokban

\begin{tabular}{l|rrrrrrrr} 
& DROME & DROSI & DROSE & DROER & DROYA & DROAN & DROPS & DROPE \\
DROME & $100 \%$ & $91 \%$ & $90 \%$ & $81 \%$ & $79 \%$ & $53 \%$ & $23 \%$ & $23 \%$ \\
DROSI & $91 \%$ & $100 \%$ & $96 \%$ & $79 \%$ & $76 \%$ & $52 \%$ & $24 \%$ & $24 \%$ \\
DROSE & $90 \%$ & $96 \%$ & $100 \%$ & $78 \%$ & $75 \%$ & $53 \%$ & $24 \%$ & $24 \%$ \\
DROER & $81 \%$ & $79 \%$ & $78 \%$ & $100 \%$ & $80 \%$ & $54 \%$ & $22 \%$ & $22 \%$ \\
DROYA & $79 \%$ & $76 \%$ & $75 \%$ & $80 \%$ & $100 \%$ & $52 \%$ & $21 \%$ & $21 \%$ \\
DROAN & $53 \%$ & $52 \%$ & $53 \%$ & $54 \%$ & $52 \%$ & $100 \%$ & $22 \%$ & $22 \%$ \\
DROPS & $23 \%$ & $24 \%$ & $24 \%$ & $22 \%$ & $21 \%$ & $22 \%$ & $100 \%$ & $100 \%$ \\
DROPE & $23 \%$ & $24 \%$ & $24 \%$ & $22 \%$ & $21 \%$ & $22 \%$ & $100 \%$ & $100 \%$
\end{tabular}

$100 \%$

$50 \%$

$0 \%$

B BigH1 C-terminális doménszekvenciák összehasonlítása különbözö Drosophila fajokban

$\begin{array}{rrrrrrrrr} & \text { DROME } & \text { DROSI } & \text { DROSE } & \text { DROER } & \text { DROYA } & \text { DROAN } & \text { DROPS } & \text { DROPE } \\ \text { DROME } & 100 \% & 91 \% & 92 \% & 80 \% & 84 \% & 59 \% & 32 \% & 45 \% \\ \text { DROSI } & 91 \% & 100 \% & 98 \% & 80 \% & 85 \% & 57 \% & 32 \% & 46 \% \\ \text { DROSE } & 92 \% & 98 \% & 100 \% & 80 \% & 85 \% & 58 \% & 32 \% & 45 \% \\ \text { DROER } & 80 \% & 80 \% & 80 \% & 100 \% & 85 \% & 56 \% & 26 \% & 40 \% \\ \text { DROYA } & 84 \% & 85 \% & 85 \% & 85 \% & 100 \% & 59 \% & 30 \% & 43 \% \\ \text { DROAN } & 59 \% & 57 \% & 58 \% & 56 \% & 59 \% & 100 \% & 27 \% & 38 \% \\ \text { DROPS } & 32 \% & 32 \% & 32 \% & 26 \% & 30 \% & 27 \% & 100 \% & 86 \% \\ \text { DROPE } & 45 \% & 46 \% & 45 \% & 40 \% & 43 \% & 38 \% & 86 \% & 100 \%\end{array}$

C H1 N-terminális doménszekvenciák összehasonlítása különbözö Drosophila fajokban

$\begin{array}{rrrrrrrrr} & \text { DROME } & \text { DROSI } & \text { DROSE } & \text { DROER } & \text { DROYA } & \text { DROAN } & \text { DROPS } & \text { DROPE } \\ \text { DROME } & 100 \% & 93 \% & 87 \% & 85 \% & 91 \% & 80 \% & 74 \% & 74 \% \\ \text { DROSI } & 93 \% & 100 \% & 89 \% & 87 \% & 87 \% & 78 \% & 72 \% & 72 \% \\ \text { DROSE } & 87 \% & 89 \% & 100 \% & 85 \% & 80 \% & 74 \% & 70 \% & 70 \% \\ \text { DROER } & 85 \% & 87 \% & 85 \% & 100 \% & 83 \% & 78 \% & 74 \% & 74 \% \\ \text { DROYA } & 91 \% & 87 \% & 80 \% & 83 \% & 100 \% & 78 \% & 74 \% & 74 \% \\ \text { DROAN } & 80 \% & 78 \% & 74 \% & 78 \% & 78 \% & 100 \% & 80 \% & 80 \% \\ \text { DROPS } & 74 \% & 72 \% & 70 \% & 74 \% & 74 \% & 80 \% & 100 \% & 100 \% \\ \text { DROPE } & 74 \% & 72 \% & 70 \% & 74 \% & 74 \% & 80 \% & 100 \% & 100 \%\end{array}$

D H1 C-terminális doménszekvenciák összehasonlítása különböző Drosophila fajokban

$\begin{array}{rrrrrrrrr} & \text { DROME } & \text { DROSI } & \text { DROSE } & \text { DROER } & \text { DROYA } & \text { DROAN } & \text { DROPS } & \text { DROPE } \\ \text { DROME } & 100 \% & 93 \% & 93 \% & 85 \% & 86 \% & 71 \% & 63 \% & 62 \% \\ \text { DROSI } & 93 \% & 100 \% & 96 \% & 83 \% & 84 \% & 71 \% & 60 \% & 59 \% \\ \text { DROSE } & 93 \% & 96 \% & 100 \% & 83 \% & 83 \% & 68 \% & 60 \% & 58 \% \\ \text { DROER } & 85 \% & 83 \% & 83 \% & 100 \% & 90 \% & 73 \% & 65 \% & 63 \% \\ \text { DROYA } & 86 \% & 84 \% & 83 \% & 90 \% & 100 \% & 71 \% & 64 \% & 63 \% \\ \text { DROAN } & 71 \% & 71 \% & 68 \% & 73 \% & 71 \% & 100 \% & 71 \% & 71 \% \\ \text { DROPS } & 63 \% & 60 \% & 60 \% & 65 \% & 64 \% & 71 \% & 100 \% & 99 \% \\ \text { DROPE } & 62 \% & 59 \% & 58 \% & 63 \% & 63 \% & 71 \% & 99 \% & 100 \%\end{array}$

5. Függelék táblázat. A) BigH1 N-terminális, B) BigH1 C-terminális, C) H1 N-terminális és D) H1 Cterminális doménszekvenciák hasonlósága Drosophila fajok között, szekvencia illesztés alapján. A mátrix átlót (teljes egyezés) sárga szín jelöli. 


\section{RÖVIDÍTÉSEK JEGYZÉKE}

3R

bp

CRISPR

CTD

DNáz

DNS

dNTP

F primer

FRAP

GD

GFP

gRNS

loxP

MNáz

mRNS

MZT

NA

NC

NTD

PAM

PCAF

PCNA

PCR

PGC

PI

Polll

PTM

QINESIn

qPCR

R primer
3. kromoszóma jobb karja

bázispár

Clustered Regularly Interspaced Short Palindromic Repeats

C (karboxi)-terminális domén

dezoxiribonukleáz

dezoxiribonukleinsav

dezoxinukleotid-trifoszfát

forward primer

Fluorescence recovery after photobleaching

globuláris domén

green fluorescent protein

guide ribonukleinsav

locus of X-over P1

mikrokokkális nukleáz

messenger ribonukleinsav

maternális-zigótikus tranzíció

numerikus apertúra

nuclear cycle

$\mathrm{N}$ (amino)-terminális domén

Protospacer Adjacent Motif

P300/CBP-associated factor

Proliferating cell nuclear antigen

polymerase chain reaction

primordial germ cell

propídium-jodid

RNS Polimeráz II

poszttranszlációs módosítás

Quantitative Imaging of the Nuclei after Elution with

Salt/Intercalators

kvantitatív PCR

reverz primer 
RNS

RT-PCR

SLIC

TE

UTR

VT ribonukleinsav

reverz transzkripció PCR

Sequence and Ligation Independent Cloning

transzpozábilis elem

untranslated region

vad típus 